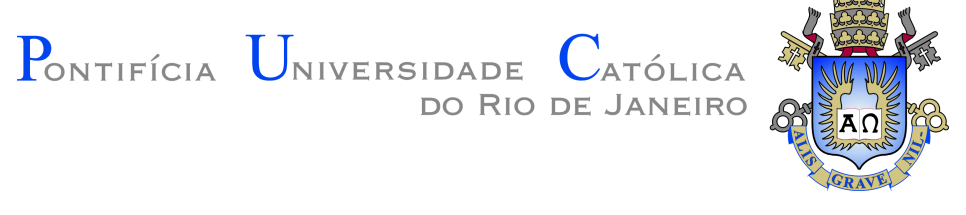

Luiz Henrique da Silva Santos

Objeto, Forma e Análise Clarificatória no

Tractatus de Wittgenstein

Dissertação de Mestrado

Dissertação apresentada como requisito parcial para a obtenção do grau de Mestre pelo Programa de Pós-graduação em Filosofia da PUC-Rio .

Orientador: Prof. Dr. Ludovic Soutif 


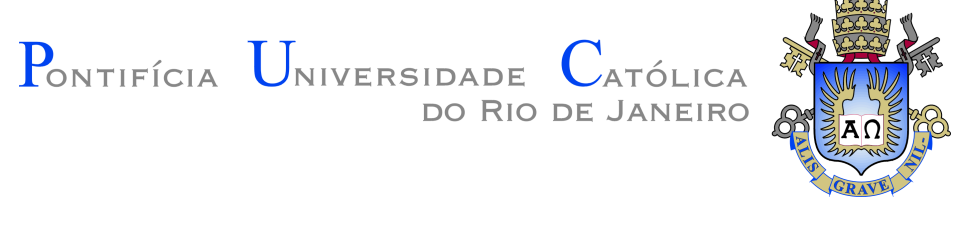

Luiz Henrique da Silva Santos

\title{
Objeto, Forma e Análise Clarificatória no Tractatus de Wittgenstein
}

\begin{abstract}
Dissertação apresentada como requisito parcial para a obtenção do grau de Mestre pelo Programa de Pós-graduação em Filosofia da PUC-Rio . Aprovada pela Comissão Examinadora abaixo.
\end{abstract}

\author{
Prof. Dr. Ludovic Soutif \\ Orientador \\ Departamento de Filosofia - PUC-Rio
}

Prof. Dr. Luiz Carlos Pinheiro Dias Pereira

Departamento de Filosofia - PUC-Rio

Prof. Dr. Edgar da Rocha Marques

Departamento de Filosofia - UERJ

Rio de Janeiro, 26 de abril de 2021 
Todos os direitos reservados. É proibida a reprodução total ou parcial do trabalho sem autorização da universidade, do autor e do orientador.

\section{Luiz Henrique da Silva Santos}

Graduado em Filosofia pela Universidade Federal de Alagoas.

Ficha Catalográfica

Santos, Luiz Henrique da Silva

Objeto, Forma e Análise Clarificatória no Tractatus de Wittgenstein / Luiz Henrique da Silva Santos; orientador: Ludovic Soutif. - Rio de janeiro: PUC-Rio , Departamento de Filosofia, 2021.

v., 113 f: il. color. ; $30 \mathrm{~cm}$

Dissertação (mestrado) - Pontifícia Universidade Católica do Rio de Janeiro, Departamento de Filosofia.

Inclui bibliografia

1. Filosofia - Teses. 2. Primeiro Wittgenstein;. 3. Objeto;. 4. Forma;. 5. Análise.. I. Soutif, Ludovic. II. Pontifícia Universidade Católica do Rio de Janeiro. Departamento de Filosofia. III. Título. 


\section{Agradecimentos}

Ao meu orientador, professor Ludovic Soutif, pela preocupação com minha formação e pela confiança na liberdade do meu pensamento.

Ao professor Luiz Carlos Pereira, pela crítica construtiva e estímulo constante às minhas ideias.

Ao professor Marcos Silva, pela motivação, parceria e colaboração sem as quais meu mestrado não teria acontecido.

À professora Juliele Sievers, pela amizade e pelo coração gigante.

Ao professor Edgar Marques, pelas valiosas observações sobre o meu trabalho.

Aos amigos que me ajudaram a sobreviver na zona sul do Rio: João, Glauber, Gabriel, Amanda, Pastel, Neit, Rio, Eric e Klaus

Aos amigos Nildo, Robsão, Denison, Max e Wáblio (intruso) pelo incentivo, camaradagem, ajuda e presença na minha caminhada.

À Cinthya, por todo o apoio, paciência e compreensão.

Ao CNPq, à FAPERJ, à CAPES e à PUC-Rio, pelos auxílios concedidos, sem os quais este trabalho não poderia ter sido realizado

O presente trabalho foi realizado com apoio da Coordenação de Aperfeiçoamento de Pessoal de Nível Superior - Brasil (CAPES) - Código de Financiamento 001 


\section{Resumo}

Santos, Luiz Henrique da Silva; Soutif, Ludovic. Objeto, Forma e Análise Clarificatória no Tractatus de Wittgenstein. Rio de Janeiro, 2021. 113p. Dissertação de Mestrado - Departamento de Filosofia, Pontifícia Universidade Católica do Rio de Janeiro.

Abordaremos a noção de objeto no Tractatus Logico-Philosophicus (1921) de Wittgenstein, inicialmente a partir do assim chamado "argumento da substância”. O discurso sobre as condições necessárias para o sentido proposicional não pode, no Tractatus, ser tratado em termos de verdade ou falsidade sem que isto acarrete um regresso ad infinitum. Uma tal situação é evitada através da postulação de uma substância constituída por objetos simples, garantindo assim o pressuposto da total determinação do sentido. Passagens dos Notebooks (1914-1916) sugerem que a ideia do simples está contida na ideia de análise lógica e é alcançada sem a necessidade de exemplos para objetos. Outras observações do primeiro Wittgenstein, contudo, oferecem exemplos para os objetos pautados em itens de natureza fenomênica, como um ponto no campo visual. Uma analogia importante para a abordagem fenomênica do objeto, encontrada nos aforismos 2.013-2.0131 do Tractatus, apresenta um problema para sua simplicidade absoluta. Este problema envolve a noção de forma, conceito que atribui ao objeto uma dependência ontológica dada por sua capacidade essencial de ocorrência em fatos atômicos. A forma dos objetos resulta da apropriação do Princípio do Contexto utilizado por Frege em seus Grundlagen der Arithmetik (1884) e difere das noções de forma de afiguração e forma lógica. A dependência atribuída ao objeto através de sua forma contradiz a subsistência independente estabelecida por sua simplicidade. O objeto tractariano resulta de demandas necessárias para a determinação do sentido proposicional, alcançadas por meio de uma análise clarificatória que prioriza os modos de análise transformativo e regressivo. Simplicidade e Princípio do Contexto são, sob esta perspectiva, regras de uma sintaxe para um uso lógico ou significativo da linguagem, as quais são refletidas na ontologia tractariana pela ideia de que a investigação lógico-filosófica da linguagem revela aspectos essenciais da estrutura íntima do mundo.

\section{Palavras-chave}

Primeiro Wittgenstein; Objeto; Forma; Análise. 


\section{Abstract}

Santos, Luiz Henrique da Silva; Soutif, Ludovic (Advisor). Object, Form and Clarificatory Analysis in Wittgenstein's Tractatus. Rio de Janeiro, 2021. 113p. Dissertação de Mestrado - Departamento de Filosofia, Pontifícia Universidade Católica do Rio de Janeiro.

We'll approach the notion of object in Wittgenstein's Tractatus LogicoPhilosophicus (1921), initially from the so-called "substance argument". The discourse about necessary conditions for the propositional sense cannot be treated in terms of truth or falsity in the Tractatus without resulting in a infinite regress. Such a situation is avoided by postulating a substance made up of simple objects, thus ensuring the assumed total determination of sense. Passages from the Notebooks (1914-1916) suggest that the idea of simples is given in the ideia of logical analysis and is reached without the necessity of examples for objects. Another early Wittgenstein's remarks provide examples for objects based on itens of phenomenical nature, such as a point in the visual field. An important analogy for the phenomenical approach for the object, which is found in the aphorisms 2.013-2.0131 of Tractatus, presents a problem for the absolute simplicity. This problem concerns the notion of form, a concept that attributes an ontological dependence to the object given by its essencial capacity of occurrence in atomic facts. The form of the objects results from an appropriation of the Context Principle used by Frege in his Grundlagen der Arithmetik (1884) and differs from the notions of pictorial form and logical form. The dependence assigned to the object through its form contradicts the independent subsistence established by its simplicity. The Tractarian object results from necessary demands for determination of propositional sense, reached by means of an clarificatory analysis which prioritizes the transformative and regressive modes of analysis. Simplicity and Context Principle are, under this perspective, rules of a syntax for a logical or significative use of language, which are reflected in the Tractarian ontology through the ideia that the logico-philosophical investigation of language reveals essencial aspects of the intimate structure of the world.

\section{Keywords}

Early Wittgenstein; Object; Form; Analysis. 


\section{Sumário}

$\begin{array}{llr}1 & \text { Introdução } & 9\end{array}$

2 Investigando a noção de objeto $\quad 14$

$\begin{array}{lll}2.1 \text { O argumento da substância } & 16\end{array}$

2.2 Espaço, tempo e cor 31

2.3 Conflito entre duas demandas 38

3 Formas no Tractatus $\quad 42$

3.1 Frege, Wittgenstein e o Princípio do Contexto 48

4 Objeto Tractariano e Análise Clarificatória $\quad 65$

4.1 O requerimento da análise completa 66

4.2 Modos de análise no Tractatus $\quad 73$

4.3 Objeto e gramática/sintaxe lógica 83

5 Conclusão 104

$\begin{array}{llr}6 & \text { Referências bibliográficas } & 108\end{array}$ 
Entender o verdadeiro sentido das coisas é querer saber demais...

Fernando Anitelli, Sonho de uma Flauta. 


\section{1 \\ Introdução}

A abordagem filosófica apresentada pelo primeiro Wittgenstein se preocupa com os problemas filosóficos, defendendo que "a formulação desses problemas repousa sobre o mau entendimento da lógica de nossa linguagem" ${ }^{\text {. Seu }}$ Tractatus Logico-Philosophicus ${ }^{2}$ deve, seguindo esse mote, fornecer os meios para que se alcance o correto entendimento da lógica da linguagem, estancando problemas filosóficos ao prevenir sua formulação. Na perseguição deste objetivo, uma diretriz explicitamente central é a ideia de que aquilo que é estabelecido logicamente deve possuir uma natureza totalmente a priori, isto é, anterior à qualquer experiência empírica do mundo (T 5.551-2). Não se trata de uma descrição de um fato particular, mas de uma descrição completa da realidade ( $\mathrm{T}$ 4.023). O correto entendimento da lógica da linguagem logrado pelo filósofo fornece a essência de toda proposição e, como consequência, é alcançada a essência do mundo ( $\mathrm{T}$ 5.4711).

A filosofia tractariana é baseada na distinção entre aquilo que pode ser dito significativamente, i.e., todo discurso que pode ser verdadeiro ou falso, e o que pode apenas ser mostrado. O método correto para a filosofia, de acordo com o Tractatus, é o de não dizer nada que não possa ser dito; o que pode ser dito, por sua vez, diz respeito ao domínio das ciências naturais, não da filosofia ( $\mathrm{T}$ 6.53). Não existe algo como uma proposição filosófica porque a filosofia não fala sobre o mundo - trata-se de uma atividade de clarificação lógica dos pensamentos, não de uma teoria ( $\mathrm{T}$ 4.112). A fim de empreender essa tarefa clarificatória, mostrando aquilo que o discurso significativo é incapaz de dizer, o filósofo deve atentar para a aplicação lógico-sintática da linguagem, que mostra aquilo que não é expresso pelos sinais linguísticos (T 3.262). É somente nesta aplicação que a forma lógica de um sinal pode ser determinada (T 3.327).

Todo discurso significativo representa situações no mundo e os nomes garantem a possibilidade dessa representação ao serem arbitrariamente correlacionados a objetos. A teoria da figuração concebe a proposição como um

${ }^{1}$ Wittgenstein, 2017, p. 125 [60].

${ }^{2}$ Doravante, refiro-me a este livro, publicado pela primeira vez em 1921 sob o título Logisch-philosophische Abhandlung, simplesmente como "Tractatus"; referências indiretas são indicadas parenteticamente pela sigla "T" seguida da numeração do aforismo correspondente. Além da excelente tradução ao português de Luiz H. L. Santos (Wittgenstein, 2017 [60]) e do texto original, foram consultadas as duas famosas traduções ao inglês, a primeira de C.K. Ogden (1922) e a segunda de D. F. Pears e B. F. McGuinnness (1961). Estas últimas podem ser consultadas online no projeto de Kevin Klement (Wittgenstein, 2018 [61]). 
modelo da realidade e aproxima linguagem e mundo de tal maneira que não há diferença entre perguntar o que é uma sentença e o que é um fato ${ }^{3}$. Em certo sentido, as duas esferas são uma só, pois compartilham a mesma estrutura lógica ( $\mathrm{T}$ 4.014). O tipo mais simples de proposição é a proposição elementar, que assere a existência de um fato atômico (T 4.21). Assim como a proposição elementar é constituída pela concatenação de nomes, um fato atômico é formado por objetos numa dada configuração ( $\mathrm{T}$ 2.0272). A relação entre sinal linguístico e coisa nomeada é de suma importância pois nela é baseada a possibilidade mesma da proposição ( $\mathrm{T}$ 4.0312) e do caráter determinado do sentido (T 3.23). Os objetos que constituem os fatos atômicos são o significado dos nomes próprios ou sinais simples ( $\mathrm{T} 3.02-3$ ).

Durante nossa investigação, exploraremos a filosofia de Wittgenstein com o objetivo de entender como é concebida a noção de objeto no Tractatus. Uma tal investigação envolve aspectos concernentes à noção mesma de significado, um conceito central para a discussão em filosofia da linguagem. É também importante notar que a concepção de filosofia do primeiro Wittgenstein adiciona uma dificuldade à nossa tentativa de entendimento. Uma explicação sobre a noção de objeto baseia os termos de uma teoria sobre a natureza do significado de nossas expressões linguísticas, mas até que ponto podemos atribuir uma teoria do significado ao primeiro Wittgenstein? As proposições filosóficas são, de acordo com o próprio Tractatus, nada mais que contrassensos. Como seria possível, então, escrever uma teoria sobre algo que não pode ser dito, somente se mostra?

A necessidade de uma atenção para com a metafilosofia tractariana evidencia-se tão logo iniciamos nossa investigação sobre a noção de objeto. Um bom pedaço de evidência sobre este conceito aparece nos aforismos 2.0211-2 e aqui é interessante notar um esboço de argumento, o qual é uma espécie de comentário indireto à ideia, colocada no aforismo 2.02, de que objetos são simples. Dada a importância da noção de objeto simples para o quadro teórico atomista defendido pelo primeiro Wittgenstein, tal argumento certamente merece ser reconstruído e investigado. Como veremos, trata-se de uma argumentação construída em moldes transcendentais, cujas premissas tratam sobre condições para a determinação do sentido proposicional. Esta discussão nos permitirá entender como é possível que uma tal argumentação seja empreendida, mesmo que se tratem de contrassensos, os quais, por definição, não poderiam justificar ou explicar coisa alguma.

Dentre os aspectos que envolvem o objeto simples destaca-se a sua relação com a noção de análise lógica. O primeiro problema que nos colocamos diz

\footnotetext{
${ }^{3}$ Wittgenstein, 1969 , p. 52
} 
respeito à afirmação de que a ideia da simplicidade já está contida na ideia de análise. Para entender a origem da simplicidade do objeto é preciso, portanto, entender aquilo que está envolvido na noção de análise lógica praticada pelo primeiro Wittgenstein. Sob sua perspectiva, a existência do objeto simples é alcançada totalmente a priori, sem que haja necessidade de exemplos de determinados objetos. O segundo aspecto que ganha centralidade em nossa discussão concerne ao choque existente entre esta afirmação e a consideração de exemplos de natureza fenomênica para objetos, esta última alegadamente sugerida por algumas observações do primeiro Wittgenstein. Dentre estas observações, chama atenção a analogia presente nos aforismos 2.013-2.0131, na qual encontramos os termos de uma comparação entre objetos e itens de natureza fenomênica. Esta analogia estabelece uma tensão para com a simplicidade absoluta do objeto, na medida em que este último não pode ser pensado fora de um "espaço" circundante de combinações possíveis. É a partir de uma releitura desta analogia que ganha centralidade a noção de forma dos objetos, a qual está, como veremos, conectada ao uso wittgensteineano do Princípio do Contexto.

Interessa-nos, no segundo capítulo do presente trabalho, investigar os principais aspectos relacionados à noção de objeto simples e fornecer uma visão geral das diferentes interpretações sobre a sua natureza. A questão sobre como a análise desvela sua simplicidade é então colocada no contexto de nossa investigação sobre a posição segundo a qual exemplos de objetos são desnecessários devido à natureza apriorística de sua descoberta, assim como exemplos de proposições elementares concernem ao trabalho a priori do lógico enquanto filósofo. Antes de abordar a noção de análise, faz-se necessário encarar uma via de interpretação que segue um caminho oposto ao defender que certas observações do primeiro Wittgenstein permitem que objetos e proposições elementares sejam exemplificados com base em aspectos fenomênicos. Ao propor a leitura da analogia dos aforismos 2.013-2.0131 como um esforço de comparação entre objetos e itens de natureza fenomênica na tentativa de elucidar a relação essencial existente entre o objeto e sua forma, coloca-se a necessidade de um melhor entendimento sobre a concepção desta última noção no Tractatus.

O terceiro capítulo representa um esforço na caracterização da forma dos objetos. Este esforço é iniciado com a constatação de diferenças importantes no tocante às alusões do primeiro Wittgenstein sobre a noção de forma. Distinguimos, no contexto desta investigação, a noção de forma dos objetos das noções de forma de afiguração e forma lógica. A proposta desta distinção perpasssa uma discussão sobre a apropriação wittgensteineana do Princípio 
do Contexto fregeano, cuja formulação é componente importante tanto para a forma dos objetos quanto para a forma lógica. Ao identificar as diferentes nuances do uso wittgensteineano deste princípio, avançamos a explicação da forma dos objetos como resultado de uma formulação ontológica do Princípio do Contexto. Uma tal formulação é calcada, com efeito, num aspecto central da estrutura conceitual que baseia a noção de análise defendida pelo primeiro Wittgenstein: a profunda ligação existente entre a linguagem e o mundo por ela representado. O conflito que envolve a noção de objeto pode ser explicado a partir da incompatibilidade entre duas demandas sobre a linguagem: a de que sinais simples possuam seu significado de maneira independente e a de que estes mesmos sinais só tenham seu significado determinado no contexto da proposição.

Finalmente, no quarto capítulo retomamos a questão sobre a relação entre objeto e análise lógica. Para tanto, faz-se necessário uma investigação sobre os aspectos que envolvem a exigência wittgensteineana de uma única análise completa da proposição. Esta exigência se dá, sob a interpretação aqui proposta, no interior de uma noção mais ampla de análise que observa aspectos relativos a seus modos resolutivo, transformativo e regressivo, de tal modo que os dois últimos assumem maior centralidade. O modo transformativo de análise é evidenciado na ideia de que a linguagem ordinária deve ser substituída por uma notação logicamente perfeita que evita os problemas filosóficos. Não é possível, contudo, entender satisfatoriamente este aspecto sem considerar o modo regressivo de análise, este último marcado pela prerrogativa de que esta substituição ocorre através da observação de regras para uma gramática ou sintaxe lógica. Visando um maior esclarecimento sobre a noção de análise desenvolvida nesses termos, procuramos elucidar a noção de sintaxe lógica defendida no Tractatus.

Veremos durante esta investigação como as regras da sintaxe são situadas nos limites do que pode ser dito, cumprindo a importante tarefa de separar a linguagem significativa do discurso contrassensual. A sintaxe lógica, entendida como as regras para um uso lógico da linguagem, é aparentada à noção de gramática defendida e posteriormente criticada no pensamento tardio de Wittgenstein. Os contrassensos elucidativos do Tractatus são tomados como observações gramaticais cujo uso visa explicitar as regras gramaticais subjacentes ao nosso uso significativo de expressões linguísticas. A simplicidade e a forma dos objetos são, sob esta perspectiva, refletidas na linguagem pela simplicidade dos nomes próprios e pelo Princípio do Contexto. Estas duas características essenciais estão contidas na ideia da análise clarificatória na medida em que esta se preocupa com a explicitação de regras gramaticais que 
se mostram em nosso uso lógico da linguagem. 


\section{2 \\ Investigando a noção de objeto}

A formulação dos problemas filosóficos, de acordo com o Tractatus, repousa sobre um mal-entendimento da lógica de nossa linguagem. Com o intuito de evitar a formulação destes problemas, o livro pretende oferecer um meio de estabelecer um limite preciso para o que pode ser dito significativamente. Este limite divide proposições que efetivamente fazem sentido daquelas que falham em fazê-lo. Entre estas últimas estão incluídas as proposições filosóficas, que podem, contudo, ser utilizadas de uma maneira peculiar. A filosofia não deve ser encarada como uma teoria, mas como um trabalho de clarificação que proporciona uma visão correta sobre o mundo. As proposições que expressam a filosofia tractariana constituem, nas palavras de Wittgenstein, uma escada que deve ser jogada fora após o alcance desta perspectiva privilegiada.

A estrutura da escada tractariana é formada por uma metafísica que salta aos olhos logo nos primeiros aforismos do livro. O correto entendimento da lógica da linguagem está de alguma forma relacionado a uma discussão ontológica. Na base da escada estão concatenações de objetos, coisas ou entidades que constituem fatos atômicos. Entender a natureza da metafísica do Tractatus é um desafio exegético que precisa encarar a dificuldade de compatibilizar a exigência wittgensteineana do silêncio na filosofia com a ontologia apresentada na obra. Esta dificuldade é ponderada por Wittgenstein, que em uma nota dos seus Notebooks datada de junho de 1915 aponta a atitude problemática de falar sobre objetos sem, no entanto, poder sequer mencionar um deles ${ }^{1}$. Sua primeira filosofia defende como uma das condições para a significatividade de nossos enunciados a exigência de que o mundo, entendido com a totalidade dos fatos, possua substância. O discurso sobre tais condições deve ser carente de significado e a existência dos objetos, apesar de não poder ser dita significativamente, pode ser mostrada (T 4.1212).

Os primeiros aforismos do Tractatus discorrem acerca da constituição da realidade, enfatizando que o mundo é determinado por fatos, não por coisas ( $\mathrm{T}$ 1.1). A insistência em encarar a ontologia a partir de fatos é justificada pelo pressuposto de que um objeto nunca pode ocorrer isoladamente, mas está essencialmente ligado à constituição de fatos atômicos (T 2.011). Se alcançamos um fato atômico, o que temos é precisamente uma combinação de objetos, entidades ou coisas ( $\mathrm{T}$ 2.01). A possibilidade de ocorrência de

\footnotetext{
${ }^{1}$ Wittgenstein, 1961, p. 68.
} 
um objeto em fatos atômicos é a sua forma ( $\mathrm{T}$ 2.0141) e a totalidade destas possibilidades deve ser parte de sua natureza ( $\mathrm{T}$ 2.0123, 2.014). A partir do aforismo 2.02, a tese de que estes objetos são simples começa a ser elucidada e aprendemos que o mundo deve ter uma forma fixa garantida pela sua existência (T 2.026). A noção de simplicidade é explicada em termos da impossibilidade da decomposição dos objetos, o que se deve ao fato de estes formarem a substância do mundo ( $\mathrm{T}$ 2.021). Os aforismos 2.0211-2 apresentam o assim chamado "argumento da substância", no qual a existência dos objetos aparece como uma condição necessária para que a composição de figurações do mundo seja possível. De acordo com Wittgenstein, a proposição deve ser concebida como a figuração de uma situação e só pode ser verdadeira ou falsa caso concorde ou não com a realidade. Objetos garantem o aspecto representacional da linguagem devido à sua correlação com os elementos da figuração (2.1514). Esta correlação constitui a relação de afiguração que caracteriza a figura enquanto tal ( $\mathrm{T}$ 2.1513).

Outro movimento conceitual importante diz respeito ao uso de exemplos fenomênicos na elucidação do objeto tractariano. Os aforismos 2.013-2.0131 elucidam a relação entre uma coisa e seu circundante espaço de possíveis fatos atômicos a partir de uma analogia com elementos como "ponto no espaço" e "mancha no espaço visual". Além disso, é importante ter em vista a afirmação de que espaço, tempo e cor são formas dos objetos ( $\mathrm{T}$ 2.0251). Estas observações parecem atuar em favor de interpretações segundo as quais Wittgenstein utiliza itens fenomênicos como exemplos para sua concepção de objeto. Uma tal abordagem, contudo, deve lidar com a relutância de Wittgenstein em exemplificar objetos, atitude esta calcada em aspectos de sua postura filosófica. É um princípio fundamental do Tractatus que a lógica seja anterior a toda experiência daquilo que ocorre no mundo. A tentativa de explicação dos objetos em bases fenomênicas parece nos colocar no "caminho errado" de "olhar para o mundo" na tentativa de lidar com problemas filosóficos (T 5.551-2).

Inicialmente abordaremos os aforismos que tratam sobre a simplicidade e o argumento da substância. A partir deste exame será possível entender quais os pressupostos envolvidos na construção do argumento com o objetivo de escrutinar a gênese do objeto tractariano. Posteriormente, voltaremos nossa atenção para as observações de natureza fenomênica sobre o objeto, expondo as faces do conflito que se desenvolve na formulação deste conceito. Este exame revela a necessidade de uma explicação mais elaborada sobre as razões que levam à admissão da simplicidade absoluta do objeto a partir da análise lógica da linguagem. É preciso explicar, adicionalmente, como esta análise chega tanto 
à simplicidade quanto à complexidade formal do objeto, acarretando o conflito entre uma demanda atomista e uma holista. A alegada complexidade emerge nas considerações de natureza fenomênica, mais especificamente na analogia que ocorre nos aforismos 2.013-2.0131. Nosso escrutínio sobre esta passagem revela que o espaço que circunda o objeto é apressadamente tomado como o espaço lógico tractariano, enquanto esta noção aparece sempre relacionada a fatos ou proposições - não nomes ou objetos. O ponto da analogia é elucidar o vínculo entre o objeto e sua forma. A explicação proposta para a noção de forma do objeto dá conta do holismo apresentado na noção de objeto não pela admissão de um espaço formal de fatos atômicos possíveis, mas pela proximidade deste conceito com o Princípio do Contexto.

\section{1}

\section{0 argumento da substância}

Os aforismos 2.0211-2 do Tractatus apresentam o cerne daquilo a que a literatura se refere como "argumento da substância"2. Nas palavras de Wittgenstein:

2.0211 Se o mundo não tivesse substância, ter ou não sentido uma proposição dependeria de ser ou não verdadeira uma outra proposição.

2.0212 Seria então impossível traçar uma figuração do mundo (verdadeira ou falsa). ${ }^{3}$

Um vislumbre sobre estas observações é suficiente para a constatação de que o argumento envolve três conceitos de peso em sua formulação. Esta é, com efeito, a primeira ocorrência das noções de sentido e verdade de uma proposição no texto do livro. O que está em jogo é a possibilidade do traçado de figurações do mundo. Este argumento mantém um laço estreito com a visão do primeiro Wittgenstein sobre a natureza representacional da linguagem. Para entender esta intricada relação entre substância, sentido, verdade e figuração, é importante que alcancemos clareza sobre a estrutura do argumento, investigando os pressupostos envolvidos em sua construção.

Devemos ter em mente a dificuldade de falar sobre argumentos ou justificações filosóficas no contexto tractariano. De acordo com Proops ${ }^{4}$, reconhecer o argumento da substância como uma justificação de pleno direito implica tratarmos suas observações como portadoras de sentido. Para que uma proposição seja significativa, de acordo com o Tractatus, ela deve representar uma

${ }^{2}$ Morris (2008 [43], 2013 [44]); Proops (2004 [47]).

${ }^{3}$ Wittgenstein, 2017, p. $133[60]$.

${ }^{4} 2004$, p. 107 [47]. 
situação no mundo. Os contrassensos que constituem o livro não cumprem esta função e, deste modo, identificar um argumento nos aforismos do livro seria algo questionável. O argumento em questão, contudo, possui a forma de um argumento transcendental, caracterizado pela afirmação "para que $Y$ seja possível, $X$ deve ser o caso". Neste caso, temos um argumento transcendental dirigido pela verdade, de acordo com o qual a existência da substância $(X)$ é tomada como condição necessária para a composição de figurações $(Y)$. Na afirmação transcendental que caracteriza este argumento, a ratio cognoscendi é não-empírica e a ratio essendi não deve sua verdade às leis da natureza ${ }^{5}$. A argumentação transcendental permite que Wittgenstein estabeleça certas "propriedades" do mundo sem o comprometimento de seu princípio fundante, de acordo com o qual questões empíricas não devem contaminar a investigação apriorística da lógica.

Os aforismos 2.0211-2 coadunam com a impressão de que exemplos de objetos não são necessários para que alcancemos a conclusão de que o mundo deve possuir uma substância. Esta perspectiva é acolhida por Wittgenstein em diferentes ocasiões. O que é estabelecido logicamente deve possuir uma natureza totalmente a priori, isto é, independente e anterior a qualquer experiência empírica do mundo. A prevalência do ponto de vista apriorístico da lógica na investigação filosófica é um princípio básico do Tractatus:

5.551 Nosso princípio básico é que toda questão que se possa decidir por meio da lógica deve poder-se decidir de imediato.

(E se chegamos à situação de ter que olhar o mundo para solucionar tal problema, isso mostra que seguimos uma trilha errada por princípio).

5.552 A "experiência" de que precisamos para entender a lógica não é a de que algo está assim e assim, mas a de que algo é: mas isso não é experiência.

A lógica é anterior a toda experiência - de que algo é assim. Ela é anterior ao como, não é anterior ao quê. ${ }^{6}$

A tentativa de exemplificar objetos vai diretamente de encontro à perspectiva esboçada nestes aforismos. Durante uma conversa recordada por Norman Malcolm, Wittgenstein torna este ponto ainda mais claro, reforçando a irrelevância da exemplificação de objetos no trabalho filosófico:

Uma anedota deve ser registrada. Eu perguntei a Wittgenstein se, quando ele escreveu o Tractatus, ele já tinha decidido sobre algo como um exemplo de um 'objeto simples'. Sua resposta foi que naquele tempo seu pensamento tinha sido o de que ele era um lógico; e que não era

${ }^{5}$ Robert Stern, 2000, p. 10 [59].

${ }^{6}$ Wittgenstein, 2017, p. $225[60]$. 
seu negócio, enquanto um lógico, tentar decidir se essa coisa ou aquela era uma coisa simples ou uma coisa complexa, o que era um assunto puramente empírico! Era claro que ele tomava sua opinião anterior como absurda. ${ }^{7}$

O argumento da substância é levado a cabo com o uso de premissas nãoempíricas e sua conclusão segue por modus tollens ${ }^{8}$. Em sua construção padrão, argumentos transcendentais apresentam a seguinte estrutura:

a. $\neg X \rightarrow \neg Y$

b. $Y$

$\therefore X$

Reconstruíremos o argumento com o auxílio do seguinte dicionário de sentenças atômicas:

P: O mundo possui substância.

Q: O sentido de uma proposição depende da verdade de outra proposição.

R: É possível fazer figurações verdadeiras ou falsas do mundo.

Podemos concluir, por transitividade, que se o mundo não possui substância $(\neg P)$ não é possível fazer figurações do mundo $(\neg R)$, pois o sentido de uma proposição dependeria da verdade de outra proposição $(Q)$ :

$$
\begin{aligned}
& \text { 1. } \neg P \rightarrow Q \\
& \text { 2. } Q \rightarrow \neg R \\
& \therefore \neg P \rightarrow \neg R
\end{aligned}
$$

Deste modo, prosseguimos com a argumentação em moldes transcendentais, cuja premissa menor assere a possibilidade de fazer figurações do mundo $(R)$, concluindo assim a existência da substância $(P)$ por modus tollens:

3. $\neg P \rightarrow \neg R$

4. $R$

$\therefore P$

É importante notar que a ideia de que existe uma dependência entre o sentido de uma proposição e a verdade de outra proposição deve ser falsa $(\neg Q)$ - i.e., sentido e verdade devem ser independentes - caso figurações sejam possíveis $(R)$ :

7 "One anecdote should be recorded. I asked Wittgenstein whether, when he wrote the Tractatus, he had ever decided upon anything as an example of a 'simple object'. His reply was that at that time his thought had been that he was a logician; and that it was not his business, as a logician, to try to decide whether this thing or that was a simple thing or a complex thing, that being a purely empirical matter! It was clear that he regarded his former opinion as absurd." (Malcolm e Wright, 2001, p. 70 [39].

${ }^{8}$ Soutif, 2013, p. 106. 
2. $Q \rightarrow \neg R$

4. $R$

$\therefore \neg Q$

Por fim, retornando à premissa de que se o mundo não possuísse substância $(\neg P)$, o sentido de uma proposição dependeria da verdade de outra $(Q)$, podemos concluir a existência da substância através de outra negação do consequente:

$$
\begin{aligned}
& \text { 2. } \neg P \rightarrow Q \\
& \text { 5. } \neg Q \\
& \therefore P
\end{aligned}
$$

Com o objetivo de simplificar a exposição do argumento, é possível uma reformulação de seus termos em forma de um reductio ad absurdum ${ }^{9}$, resultando na seguinte estrutura:

Suponhamos que

[1] Não existe substância; Neste caso,

[2] O sentido de uma proposição depende de ser verdadeira ou não outra proposição;

Assim,

[3] Não seria possível traçar figurações (verdadeiras ou falsas) do mundo.

Contudo,

[4] É possível traçar figurações do mundo.

[4] e [3] entram em contradição.

Logo,

[5] A substância existe.

Esta exposição possibilita a identificação das premissas que compõem o argumento e facilita a identificação de seus pressupostos. A possibilidade de esboçar figurações verdadeiras ou falsas está condicionada à existência da substância porque sem esta última o sentido de uma proposição dependeria sempre de ser verdadeira ou não outra proposição. Deste modo, o argumento nos ensina que figurações só são possíveis caso o sentido de uma proposição seja independente do valor de verdade de qualquer outra. Mas o que, exatamente, isto significa? Por que não seria possível traçar figurações verdadeiras ou falsas do mundo caso o sentido de uma proposição dependesse da verdade de uma outra proposição? Por que o sentido de uma proposição dependeria da verdade de outra proposição caso não existisse uma substância? Para entender o que está em jogo no argumento da substância, é necessário explicar o que significa

${ }^{9}$ Esta reformulação é feita por Proops (2004 [47]). 
a referida dependência do sentido de uma proposição para com a verdade ou falsidade de uma outra proposição. Além disso, é preciso esclarecer como, exatamente, esta dependência representa um problema para a viabilidade da teoria da figuração.

\subsection{1}

\section{Independência entre sentido e verdade}

O insight que motiva a concepção figurativa da linguagem pode ser vislumbrado na seguinte nota, escrita por Wittgenstein em setembro de 1914:

O conceito geral da proposição carrega um conceito muito geral da coordenação entre proposição e fato atômico: a solução para todas as minhas questões deve ser extremamente simples.

Na proposição um mundo é ajuntado e justaposto experimentalmente. (Como quando um acidente de carro é representado por meio de bonecos, etc., no tribunal parisiense.)

Disto deve resultar imediatamente a natureza da verdade (caso não sejamos cegos).

Pensemos na escrita hieroglífica, na qual cada palavra representa seu significado! Pensemos nisso, que figurações reais de fatos atômicos podem ser corretas e incorretas.

[...] A proposição na escrita figurativa pode ser verdadeira e falsa. Ela tem um sentido independentemente de sua verdade ou falsidade. Deve ser possível demonstrar tudo de essencial a partir disso. ${ }^{10}$

Aprendemos com esta passagem que é possível alcançar diretamente a natureza da verdade caso tenhamos a visão correta sobre o conceito geral da proposição - caso não predomine uma espécie de cegueira. Apesar de a solução das questões ser extremamente simples, o que está em jogo aqui é algo diferente da simplicidade atribuída aos objetos. Para o primeiro Wittgenstein, parece existir uma perspectiva a partir da qual podemos encarar a linguagem que permite o alcance de ideias fundamentais para sua filosofia.

Ao prescrutrar o conceito de proposição, é preciso ter em mente que ele carrega consigo o conceito geral da coordenação entre proposição e situação.

10"Der allgemeine Begriff des Satzes führt auch einen ganz allgemeinen Begriff der Zuordnung von Satz und Sachverhalt mit sich: Die Lösung aller meiner Fragen muß höchst einfach sein!

In Satz wird eine Welt probeweise zusammengestellt. (Wie wenn in Pariser Gerichtssaal ein Automobilunglück mit Puppen etc. dargestellt wird.)

Daraus muß sich (wenn ich nicht blind wäre) sofort das Wesen der Wahrheit ergeben.

Denken wir an hieroglyphische Schriften, bei denen jedes Wort seine Bedeutung darstellt! Denken wir daran, daß auch wirkliche Bilder von Sachverhalten stimmen und nicht stimmen können. [...]

Der Satz in Bilderschrift kann wahr und falsch sein. Er hat einen Sinn unabhängig von seiner Wahr-oder Falschheit. An ihm muß sich alles Wesentliche demonstrieren lassen." (Wittgenstein, 1969, p. 7 [62].) 
Considerando este conceito geral, aquilo de essencial em nossa linguagem salta à vista. Exemplos simples de como nós representamos situações em nosso uso da linguagem permitem que entendamos a essência desta última. Olhando o modo como um acidente de carro pode ser representado num tribunal por meio de bonecos, ou mesmo como cada imagem representa algo na escrita hieroglífica, três insights que demonstram tudo aquilo de essencial são apontados nesta anotação: (i) uma figura deve ser composta por elementos que correlacionados biunivocamente a outros; (ii) figuras de situações podem ser verdadeiras ou falsas; e (iii) a proposição na escrita pictográfica possui um sentido independente de sua verdade ou falsidade. No Tractatus, expressões destes insights ocorrem nas seguintes passagens:

(i) 2.13 Aos objetos correspondem, na figuração, os elementos da figuração.

(ii) 2.21 A figuração concorda ou não com a realidade; é correta ou incorreta, verdadeira ou falsa.

(iii) 2.22 A figuração representa o que representa, independentemente de sua verdade ou falsidade, por meio da forma de afiguração.

O que encontramos em (ii) é a expressão da tese da bipolaridade da proposição. A bipolaridade é considerada o traço mais essencial do enunciado e encontra sua expressão no princípio da não contradição. Este princípio possui uma formulação ontológica, de acordo com a qual "ele afirma ser impossível que algum atributo pertença e não pertença a alguma coisa ao mesmo tempo e sob o mesmo aspecto"; e uma formulação lógica, segundo a qual "ele afirma que nada se pode afirmar e negar da mesma coisa ao mesmo tempo e sob o mesmo aspecto"11. Esta tese, que remonta a Aristóteles ${ }^{12}$, "é formulada para dar conta da distinção entre condições de sentido e condições de verdade de um enunciado"13.

Existe uma conexão direta entre (ii) e (iii), pois a distinção entre as esferas do sentido e da verdade de uma proposição é garantida pela formulação da tese da bipolaridade. O argumento da substância é baseado no pressuposto (ii) de que figurações verdadeiras ou falsas são possíveis. Se o mundo não tivesse substância seria impossível compor tais figurações justamente porque, neste caso, as noções de sentido e verdade não seriam independentes e isto iria de encontro com (iii). Deste modo, a garantia de (ii) e (iii) descansa sobre (i), i.e., tanto a bipolaridade quanto a independência entre sentido e verdade exigem a postulação de objetos que compõem a substância do mundo e são

\footnotetext{
${ }^{11}$ Santos, 1996, p. 8 [52].

${ }^{12}$ cf. Barbosa Filho, 2005 [3].

${ }^{13}$ Santos, 1996, p. 10 [52].
} 
precisamente aqueles que devem estar em correspondência com os elementos de uma figuração para que representações sejam possíveis. Esta possibilidade não é assegurada pela verdade de nenhuma proposição, como podemos ver no aforismo 2.22, mas pelo que Wittgenstein chama de forma de afiguração.

A formulação da tese da bipolaridade torna possível distinguir as condições para o sentido de uma proposição das suas condições de verdade. A bipolaridade é uma condição para a significatividade de uma proposição, e isto implica reconhecer que um enunciado deve sempre apresentar uma de duas possibilidades: verdadeiro ou falso. A relação de correspondência do enunciado em direção à uma situação que o satisfaça no mundo, por sua vez, é uma condição de sua verdade. A não observância desta distinção nos leva a um problema para a fundamentação da verdade e falsidade de nossos enunciados. Se a base para tomarmos um discurso como significativo for a sua correspondência com aquilo que é o caso na realidade, é impossível explicar a significatividade de enunciados falsos. Se o discurso falso é aquele que diz o que não é, isto quer dizer que ele não corresponde a situação alguma - e se sua significatividade depende desta correspondência, em realidade não veiculamos um discurso significativo por meio de sua expressão ${ }^{14}$.

A partir destas considerações podemos entender porque a dependência entre sentido e verdade de uma proposição é uma ameaça para a teoria da representação do primeiro Wittgenstein. A delimitação entre as esferas da significatividade e da verdade na linguagem é necessária para que o discurso falso seja possível e, além disso, seja distinto do discurso contrassensual. Se figurações, verdadeiras ou falsas, são possíveis, as condições que determinam o sentido da proposição devem ser distintas das condições que estabelecem seu valor de verdade. É impossível, deste modo, que a verdade de uma proposição tenha o menor impacto na tentativa de determinação do sentido de qualquer outra proposição. É impossível falar verdadeira ou falsamente sobre as condições que garantem a significatividade da nossa linguagem.

Dois pressupostos constituem a formulação do argumento da substância. O primeiro diz respeito à constatação de nosso efetivo uso de figurações, que devem poder ser verdadeiras ou falsas para que cumpram sua função representacional. Uma tal constatação pressupõe a tese da bipolaridade do discurso significativo, que por sua vez garante nosso segundo pressuposto de que condições para o sentido e condições para a verdade dos enunciados devem ocupar âmbitos distintos. Estes pressupostos estão conectados à distinção tractariana entre o que pode ser dito significativamente, i.e., todo enunciado que pode

\footnotetext{
${ }^{14}$ Este problema é, com efeito, apontado por Wittgenstein em sua crítica à teoria do juízo de Russell (cf. Hyder, 2002, p. 70[33]).
} 
ser verdadeiro ou falso, e o que pode apenas ser mostrado. Nossa investigação revela que as premissas do argumento apresentam diferentes condições para a significatividade de nossas proposições que, enquanto tais, não estão no escopo daquilo que pode ser dito com sentido. Nossos juízos significativos devem seguir o princípio da bipolaridade, devem ser ou verdadeiros ou falsos. Sendo assim, é impossível proferir juízos verdadeiros ou falsos sobre as condições que fundamentam nosso discurso - i.e., é impossível julgar contrassensos.

A esta altura é possível entender porque a composição de figurações é ameaçada caso confundamos as esferas do sentido e da verdade da proposição. Sabemos que se o sentido de uma expressão linguística dependesse da verdade de uma outra, não haveria diferença entre aquilo que é contrassenso e aquilo que é simplesmente falso. Sendo assim, para que se possa distinguir entre o que pode ser dito e o que jaz além do discurso significativo, é preciso estar atento ao fato de que a proposição deve sempre priorizar um de dois pólos, e isto não é possível caso haja uma confusão entre as esferas do sentido e da verdade. Contudo, para que nossa elucidação sobre o argumento da substância esteja completa é necessário explicar ainda como as condições de sentido nele apresentadas estão relacionadas à existência dos objetos. Em outras palavras, é preciso saber por que a independência entre sentido e verdade de uma proposição nos leva à existência da substância.

Imaginemos então que uma proposição $A$ só possui sentido se outra proposição $B$ for verdadeira. O sentido de uma figuração é aquilo que ela representa ( $\mathrm{T}$ 2.221), i.e., uma possibilidade de existência e não-existência de fatos atômicos (T 2.201); sua verdade ou falsidade consiste na concordância ou discordância desta possibilidade para com a realidade (T 2.222). Sendo assim, a verdade de nossa proposição $B$, que baseia o sentido de $A$ deve ser ela mesma portadora de um sentido a ser comparado com a realidade de tal modo que seu valor de verdade possa ser estabelecido. A questão agora deve ser levantada no tocante ao sentido de $B$ que, por definição, deve ser baseado pela verdade de uma outra proposição $C$, cujo sentido também deveria depender da verdade de outra proposição $D$ - e assim temos um regresso ad infinitum.

De acordo com o Tractatus, o sentido de figurações não descansa sobre a verdade de proposição alguma, mas sim sobre a possibilidade de que os elementos combinados na figura mantenham a mesma conexão apresentada pelos objetos no fato atômico. Esta possibilidade, chamada de forma de afiguração, depende de que existam objetos correlatos aos elementos da figuração ( $\mathrm{T}$ 2.151). Lemos claramente no Tractatus que a figuração não pode colocar-se fora de sua forma de representação e que, por este mesmo motivo, é capaz de representar seu objeto correta ou falsamente (T 2.173-4). Não é difícil obser- 
var que a forma de afiguração é o conceito utilizado por Wittgenstein em sua tentativa de lidar com o regresso sentido-verdade ${ }^{15}$, evitando cuidadosamente tratar as condições para a significatividade da linguagem em termos veritativos. É por este motivo que esta forma não se deixa figurar, mas pode apenas ser exibida ( $\mathrm{T} 2.172)$.

Se a substância não existir, não é possível fazer figurações verdadeiras ou falsas, pois estas figurações dependem de uma forma de afiguração que, por sua vez, depende da existência dos objetos. Figurações podem ser verdadeiras ou falsas devido à sua forma. O valor de verdade de uma figuração é estabelecido através da comparação das suas possibilidades de existência e não existência de fatos atômicos com a realidade. Estas possibilidades, que configuram o sentido da figuração, não podem depender da verdade ou falsidade de nenhuma proposição. A forma de afiguração é garantida pelos objetos, dos quais não se pode, com efeito, falar verdadeira ou falsamente porque é justamente a sua combinação que estrutura os fatos atômicos cuja existência e nãoexistência estabelecem as possibilidades que permitem o discurso apofântico. A proposição só pode ser um modelo lógico de uma situação se objetos são correlacionados aos seus elementos e caso isto não seja observado a própria possibilidade de representação é prejudicada ${ }^{16}$.

Até agora nossa investigação esteve concentrada em explicar os pressupostos da argumentação que ocorre nos aforismos 2.0211-2. Vimos que as premissas do argumento da substância apresentam três condições para a possibilidade do discurso significativo e mostra como duas delas, a tese da bipolaridade e a independência entre sentido e verdade, devem sua própria possibilidade à existência de uma substância. A forma de afiguração aparece como um conceito a partir do qual Wittgenstein pretende elucidar o sentido proposicional sem a necessidade do uso de sentenças passíveis de verdade ou falsidade e isto nos leva diretamente ao coração da distinção entre o que pode ser dito e o que pode ser mostrado. Condições para a significatividade da linguagem não podem ser colocadas em palavras e o argumento da substância é um argumento transcendental composto por premissas que não são consideradas significativas de acordo com os requisitos tractarianos.

A existência dos objetos possibilita uma saída ao regresso sentido-verdade e isto evita que a análise das proposições ocorra de maneira indefinida. A conexão entre estes objetos e o fim da análise lógica da linguagem lança luz sobre a noção de simplicidade, que deve nos preocupar na sequência de nosso exame. Os pressupostos que examinamos permitem a caracterização

\footnotetext{
${ }^{15}$ Esta nomenclatura é utilizada por Hyder (2002, p. 1 [33]).

${ }^{16}$ Wittgenstein, 1969, p. 12 [62].
} 
tractariana da substância, que aparece como uma consequência metafísica desta investigação transcendental. A simplicidade dos objetos, contudo, não é estabelecida pelo argumento da substância, mas está diretamente relacionada à demanda tractariana pela análise lógica da proposição.

\subsection{2}

\section{Simplicidade e análise}

A substância é conhecida em bases puramente lógicas e a afirmação de sua existência é alcançada filosoficamente no contexto de uma abordagem que aproxima a tarefa da filosofia e o trabalho de análise lógica. Esta aproximação é indicada já nos Notebooks, na seguinte observação:

Podemos dizer: temos sinais, os quais se comportam como aqueles da forma sujeito-predicado, mas isso prova que os fatos realmente devem manifestar esta forma? Isto é: quando aqueles são completamente analisados? E aqui surge novamente a questão: existe uma tal análise completa? E se não existe: qual é, então, a tarefa da filosofia?!!? ${ }^{17}$

Em outra nota, Wittgenstein afirma que a simplicidade está de alguma forma contida na ideia de análise e que a existência dos objetos é conhecida a priori como uma necessidade lógica:

Parece que a ideia do SIMPLES já está contida na do complexo e na ideia da análise, e nós prescindimos totalmente de quaisquer exemplos de objetos simples ou de proposiçoes que falam sobre eles para chegar a esta ideia, e reconhecemos a existência do objeto simples - a priori como uma necessidade lógica. ${ }^{18}$

Como, então, a ideia do simples deve ser encontrada na ideia de análise? Uma resposta pode ser proposta caso observemos a noção de análise apresentada nas passagens sob nossa consideração. Esta concepção apresenta a análise como uma tarefa de desmembramento e identificação das partes constituintes e da estrutura de um dado complexo. Sob esta perspectiva, os objetos simples, como elementos consituintes de fatos atômicos, são o produto final de um processo

17"Wir können zwar sagen: Wir haben Zeichen, die sich so benehmen, wie solche von der Subjekt-Prädikat Form, aber beweist das, daß es wirklich Tatsachen dieser Form geben muß? Nämlich: wenn diese vollständig analysiert sind. Und hier frägt es sich wieder: Gibt es so eine vollständige Analyse. Und wenn nicht: Was ist denn dann die Aufgabe der Philosophie?!!?" (Wittgenstein, 1969, p. 2 [62])

18"Es scheint daß die Idee des EINFACHEN in der des Komplexen und in der Idee der Analyse bereits enthalten liegt, so zwar daß, wir ganz absehend von irgendwelchen Beispielen einfacher Gegenstände, oder von Sätzen in welchen von solchen die Rede ist; zu dieser Idee kommen und die Existenz der einfachen Gegenstände als eine logische Notwendigkeit - a priori - einsehen." (Wittgenstein, 1969, p. 60 [62]) 
de análise lógica e conhecidos apenas indiretamente ("por descrição, por assim dizer"), mediante este processo:

Mas também isso parece certo, que nós não inferimos a existência de objetos simples a partir da existência de determinados objetos simples, mas conhecemo-los antes como o resultado final da análise - através de descrição, por assim dizer - através de um processo que conduz a eles. ${ }^{19}$

No âmbito linguístico, a análise parte de proposições complexas e revela proposições elementares, que são concatenações imediatas de nomes ( $\mathrm{T} 4.221$ ) ou signos simples ( $\mathrm{T}$ 3.202). Na contraparte ontológica, a estrutura do fato [Tatsache] é constituída pelas estruturas de fatos atômicos [Sachverhalte] (T 2.034) e cada uma destas últimas é constituída pela concatenação de objetos ( $\mathrm{T}$ 2.032). A proposição elementar é o tipo mais simples de proposição e assere a existência de um fato atômico ( $\mathrm{T}$ 4.21). Além disso, seus signos simples constitutivos devem ter como referência objetos simples (T 3.203). A substância está conectada à ideia de análise lógica porque objetos são a referência dos nomes que constituem as proposições elementares encontradas no final do trabalho analítico. Objetos marcam o ponto onde a análise completa da linguagem chega ao fim.

A necessidade de um ponto final para o processo de análise da linguagem é justificada pela ideia de que a proposição sempre expressa seu conteúdo de maneira determinada ( $\mathrm{T}$ 3.25-3.251). A proposta tractariana para a dissolução dos problemas filosóficos depende do emprego de um simbolismo que evite as confusões (das quais a filosofia está cheia) e as flutuações de significado da linguagem ordinária - um simbolismo que obedeça às regras da sintaxe ou gramática lógica ( T 3.323-5). A concepção de linguagem assim apresentada segue a ideia de que nenhuma ambiguidade deve ser tolerada caso se queira cumprir o objetivo de acabar com os problemas da filosofia. Aquilo que é expresso pelas proposições deve ser sempre expresso de modo determinado e claramente especificável (T 3.251). Uma expressão linguística deve representar fatos para ser uma proposição, deve ser uma figuração da realidade ( $\mathrm{T} 4.01$ ). A proposição, por seu turno, deve ter seu sentido completamente definido para poder ser uma figuração. Toda proposição que expressa algo deve possuir um sentido claro e preciso $^{20}$ ( $\mathrm{T}$ 4.116). Todo proferimento munido de sentido deve ser uma representação precisa do mundo.

\footnotetext{
19"Aber auch das scheint sicher, daß wir die Existenz einfacher Gegenstände nicht aus der Existenz bestimmter einfacher Gegenstände schließen, sondern sie vielmehr als Endresultat einer Analyse- sozusagen durch die Beschreibung-durch einen zu ihnen führenden Prozeß, kennen." (Wittgenstein, 1969, p. 50 [62])

${ }^{20}$ cf. Wittgenstein, 1969, p. 67-8[62].
} 
Sendo assim, no que compete ao discurso significativo, "o que se pode em geral dizer, pode-se dizer claramente; e sobre aquilo de que não se pode falar, deve-se calar" ${ }^{21}$. Esta afirmação que, de acordo com Wittgenstein, apanha todo o sentido do Tractatus, impõe uma restrição sobre aquilo que podemos alcançar por meio de nosso discurso significativo. Existem certas coisas que não podem ser colocadas em palavras mas que, de alguma maneira, tornam-se manifestas, mostram-se ( $\mathrm{T}$ 6.522). Existe assim um limite para o que pode ser dito significativamente sobre o mundo e a linguagem é capaz de mostrar, em sua aplicação ( $\mathrm{T}$ 3.262), aspectos da realidade que violam este limite. O que está para além deste marco não configura um discurso significativo e "será simplesmente contrassenso" ${ }^{22}$. É possível, contudo, pescrutar a natureza da linguagem a partir de um ponto de vista lógico e, deste modo, apontar algo que não pode ser dito. Abordar a linguagem a partir desta perspectiva implica reconhecer a natureza clara e determinada do discurso significativo. É nesse sentido que a clara representação do que pode ser dito fornece a base para que a filosofia possa significar o indizível ( $\mathrm{T}$ 4.115).

Aquilo que faz parte da essência do mundo está para além do alcance do discurso significativo e não pode ser propriamente colocado em palavras. Toda a filosofia é puro contrassenso e a filosofia tractariana certamente não é uma exceção ( $\mathrm{T}$ 6.54). Entre os contrassensos proferidos por Wittgenstein está a exigência de que a proposição possua uma única análise completa ( $\mathrm{T}$ 3.25). Subjacente à esta noção de análise está a distinção entre dois tipos de signos linguísticos que possuem modos de significação diferentes. Signos complexos são definidos por meio de signos primitivos; estes últimos, por sua vez, não podem ser dissecados por meio de definições e portam seu significado de maneira independente ( $\mathrm{T}$ 3.261). A análise das proposições por meio de definições é necessária para que cheguemos à sua real estrutura e é considerada completa quando a proposição possui a mesma complexidade de seu significado 23 .

Uma análise ad infinitum, que prossegue indefinidamente sem alcançar elementos indivisíveis, não dá conta do caráter determinado do sentido. A demanda de uma análise final e completa da proposição é baseada na manutenção do insight básico de que o discurso significativo deve ter sempre um caráter determinado. A análise de proposições deve nos levar a proposições elementares compostas por signos simples, indivisíveis, que não podem mais ser decompostos. Esta mesma ideia de análise aparece na afirmação da tese da simplicidade dos objetos no Tractatus:

\footnotetext{
${ }^{21}$ Wittgenstein, 2017, p. 125 [60] (Minha ênfase).

${ }^{22}$ Wittgenstein, 2017, p. 125 [60].

${ }^{23}$ Wittgenstein, 1969, p. 46 [62].
} 
2.02 O objeto é simples.

2.0201 Todo enunciado sobre complexos pode-se decompor em um enunciado sobre as partes desses complexos e nas proposições que os descrevem completamente.

2.021 Os objetos constituem a substância do mundo. Por isso não podem ser decompostos. ${ }^{24}$

É interessante notar a facilidade com a qual conceitos linguísticos são utilizados em meio a uma discussão ontológica. Um enunciado sobre as partes de um complexo é resultado da decomposição do enunciado que diz respeito ao complexo enquanto tal. Contudo, Wittgenstein afirma na sequência que objetos não podem ser decompostos, em vez de continuar tratando sobre signos linguísticos. O nome é, com efeito, um signo essencialmente simples e por isso funciona como objeto ${ }^{25}$. A análise que vai de enunciados complexos a enunciados mais simples parece ter uma contraparte imediata na realidade, partindo de complexos ontológicos decompostos em partes que a partir de um dado momento não podem ser decompostas.

Nesse sentido, analisar significa quebrar ou desmontar um elemento complexo e objetos não podem ser decompostos porque permanecem inalterados. A substância do mundo é constituída por objetos que não são passíveis de decomposição porque devem existir independentemente do que é o caso e garantir o que Wittgenstein chama de "forma fixa do mundo":

2.022 É óbvio que um mundo imaginário, por mais que difira do mundo real, deve ter algo - uma forma - em comum com ele.

2.023 Essa forma consiste precisamente nos objetos. [...]

2.024 A substância é o que subsiste independentemente do que é o caso. $^{26}$

Objetos são aquilo que deve permanecer enquanto sua configuração, que constitui o fato atômico, é variável ( $\mathrm{T}$ 2.0271-2). Isto significa dizer que a ocorrência de fatos atômicos é algo contingente - i.e., o mundo se divide em fatos que podem ser ou não o caso ( $\mathrm{T}$ 1.2-1.21) - e que objetos, enquanto componentes da substância inalterável de toda situação possível, subsistem tanto no mundo atual quanto em qualquer outra configuração dos fatos.

Propriedades materiais, no Tractatus, são constituídas pela configuração de objetos ( $\mathrm{T}$ 2.0231) e deste modo estes últimos são, por assim dizer, incolores ( $\mathrm{T}$ 2.0232). De acordo com Fogelin, a substância tractariana pode ser entendida em sua comparação com a concepção kantiana, de acordo

${ }^{24}$ Wittgenstein, 2017, p. 133 [60]

${ }^{25}$ Wittgenstein, 1969, p. 69 [62].

${ }^{26}$ Wittgenstein, 2017, p. 133 [60] 
com a qual substância é aquilo que persiste através de toda mudança ${ }^{27}$. O conceito de substância kantiano envolve o princípio sintético a priori da persistência que figura na mudança existencial, na qual uma coisa ou propriedade vem a ser ou deixa de existir. Este conceito é distinto da categoria da substância e diz respeito à conexão desta última com a forma pura do tempo $^{28}$. Toda mudança existencial pressupõe algo permanente e a substância kantiana é concebida como aquilo que persiste durante todo advento desta mudança através do tempo. De acordo com Proops ${ }^{29}$, enquanto a persistência apresentada por Kant deve ser entendida como a existência durante o tempo, em Wittgenstein esta deve ser entendida metaforicamente como existência em todos os mundos possíveis. Sob esta perspectiva, a simplicidade do objeto implica sua subsistência em todos os contextos de sua combinação em fatos atômicos, garantindo que mundos possíveis compartilhem algo com o mundo atual.

A ideia de simplicidade contida na noção de análise ganha consequências abrangentes, permitindo que Wittgenstein afirme teses metafísicas substantivas. A metafísica dos objetos tractarianos é reconhecida posteriormente em uma crítica ao atomismo lógico encontrada nas Investigações Filosóficas:

46. Ora, o que está por trás disso, que os nomes em verdade significam simples? -

Sócrates (no Teeteto): "De fato não me engano, assim tenho eu escutado de alguns: para os elementos primordiais - por assim dizer - dos quais nós e tudo mais somos compostos, não há nenhuma explicação; porque tudo que é em si e por si mesmo somente podemos significar com nomes; uma outra determinação não é possível, nem que seja nem que não seja... Mas o que é em si e por si mesmo deve ser... nomeado sem qualquer outra determinação. [...] Mas assim como o que é feito de elementos primordiais é em si mesmo uma estrutura interligada, também suas designações nesta interligação tornam-se discurso explicativo; pois sua essência é a interligação de nomes."

Os 'particulares' de Russell e meus 'objetos' (Tractatus LogicoPhilosophicus) eram também estes elementos primordiais. ${ }^{30}$

${ }^{27}$ Fogelin, 1995, p. 10 [17].

${ }^{28}$ Proops, 2004, p. $108[47]$

${ }^{29}$ Proops, 2004, p. 109-10 [47].

30 "46. Was hat es nun für eine Bewandtnis damit, daß Namen eigentlich das Einfache bezeichnen? -

Sokrates (im Theätetus): 'Täusche ich mich nämlich nicht, so habe ich von Etlichen gehört: für die Urelemente - um mich so auszudrücken - aus denen wir und alles übrige zusammengesetzt sind, gebe es keine Erklärung; denn alles, was an und für sich ist, könne man nur mit Namen bezeichnen; eine andere Bestimmung sei nicht möglich, weder die, es sei, noch die, es sei nicht... Was aber an und für sich ist, müsse man... ohne alle anderen Bestimmungen benennen. [...] Wie aber das, was aus diesen Urelementen sich zusammensetzt, selbst ein verflochtenes Gebilde sei, so seien auch seine Benennungen in dieser Verflechtung zur erklärenden Rede geworden; denn deren Wesen sei die Verflechtung von Namen' 
Esta citação resgatada pelo segundo Wittgenstein ocorre no contexto de uma crítica platônica ao atomismo lógico que remonta a Parmênides ${ }^{31}$. Os termos de uma comparação entre estes "elementos primários" e os objetos tractarianos são apresentados no fragmento platônico, na ideia de que a essência da linguagem é a interconexão de nomes que se referem a algo que deve ser "em si e por si mesmo". Destes elementos, não se pode afirmar que são ou não o caso, porque aquilo que ocorre - e pode, portanto, ser ou não o caso -, é resultado de sua concatenação ou separação. Objetos simples são uma marca do atomismo lógico de Wittgenstein.

Vimos que a postulação dos objetos é uma saída ao regresso sentidoverdade ocasionado por uma abordagem que baseia as condições para o sentido dos enunciados na verdade de outros enunciados. Este regresso é incompatível com a tese tractariana de que a análise lógica da linguagem deve chegar ao fim em um determinado ponto. Se esta análise leva a proposições cujo sentido deve sempre ser remetido à verdade de outras proposições, ela nunca findará e o caráter determinado do sentido será comprometido. Não é possível dar conta do fato de nossos enunciados significativos sempre veicularem um sentido determinado caso a análise continue indefinidamente.

A análise que desvela a estrutura e as partes simples constituintes de complexos deve encontrar em seu último estágio signos simples que se referem a objetos também simples. Contudo, é importante notar que Wittgenstein não se preocupa em fornecer um método para esse tipo de análise lógica das proposições e afirma saber que esta análise é possível, mas ser incapaz de executá-la completamente $^{32}$. É plausível pensarmos que sabemos sobre a existência dos objetos simples em conexão com a ideia de análise porque efetuamos, de fato, a decomposição dos complexos proposicionais, chegamos ao fim do trabalho e encontramos os referidos elementos. Entretanto, as proposições elementares que "obviamente" são encontradas através da análise não são e não podem ser exemplificadas pelo discurso filosófico, pois a filosofia procede de maneira apriorística e, consequentemente, tentar fornecer proposições elementares a priori deve levar a inevitáveis contrassensos ( $\mathrm{T}$ 5.5571). Sendo assim, a descoberta de objetos através da análise decomposicional é, por princípio, desnecessária para que atestemos a sua existência.

Uma investigação pormenorizada sobre a análise lógica do Tractatus é necessária para explicar a conexão desta com a noção de simplicidade. Wittgenstein defende que a análise deve desvelar objetos simples, mas as

Diese Urelemente waren auch Russell's 'individuals', und auch meine 'Gegenstände' (Log. Phil. Abh.)." (Wittgenstein, 2009, p. 25 [63].)

${ }^{31}$ cf. Souza, $2011[56]$.

${ }^{32}$ Wittgenstein, 1969, p. 61 [62]. 
proposições elementares formadas pela concatenação de nomes que se referem a estas entidades não são encontradas pelo filósofo. Se a filosofia e a análise lógica são próximas de alguma maneira, então qual aspecto desta análise - se não o decomposicional - permite o alcance da ideia do objeto simples? Abordaremos a temática da análise lógica com mais especificidade no terceiro capítulo deste trabalho. Antes de tentar responder a esta questão é importante observar que o problema sobre o papel da análise decomposicional na abordagem wittgensteineana decorre do nosso esforço em manter o princípio de que a filosofia e a lógica são análogas e que o filósofo não deve se envolver com questões de natureza empírica.

A força deste princípio pode, contudo, ser plausivelmente contestada caso nos atentemos a outras observações do primeiro Wittgenstein. Enquanto fragmentos como o aforismo 5.551 apontam na direção da aprioricidade da investigação lógico-filosófica, os exemplos considerados na investigação sobre o tópico da análise nos Notebooks e certas passagens do Tractatus que tratam objetos em termos fenomênicos apontam a direção contrária. Observações como estas motivam interpretações que explicam o objeto tractariano em termos das sensações relativas à nossa experiência do mundo. Esta abordagem parece distoar da pretensa separação entre questões empíricas e filosóficas, além de levantar questões sobre o papel de exemplos fenomênicos no trabalho do primeiro Wittgenstein. As considerações sobre o argumento da substância pressupõem que exemplos de objetos não são necessários para que saibamos sobre sua existência. Como veremos na sequência, isto parece não impedir que o Tractatus forneça estes exemplos nas bases de uma comparação entre objetos e itens de natureza fenomênica.

\section{2}

\section{Espaço, tempo e cor}

Durante nossas considerações anteriores vimos que um relato de Norman Malcolm apresenta Wittgenstein afirmando que objetos não devem ser exemplificados pelo filósofo. Há, contudo, uma outra conversa recordada por Desmond Lee, datada do início dos anos 30, que vai em sentido diretamente oposto ao nosso primeiro relato. Nela são apresentados o que parecem ser exemplos claros de objetos num comentário a uma passagem do Tractatus:

2.01 "Um fato atômico é a combinação de objetos (entidades, coisas)". "Objetos", etc. é aqui usado para tais coisas como uma cor, um ponto no espaço visual, etc: cf. também acima. Uma palavra não possui sentido exceto numa proposição. ${ }^{33}$ )

33" 2.01 . 'An atomic fact is a combination of objects (entities, things)'. 'Objects', etc. is 
Existe, deste modo, uma espécie de tensão nos comentários do primeiro Wittgenstein. Por um lado, aprendemos que não cabe ao filósofo a tarefa de determinar se tal e tal coisa é ou não um exemplo de objeto e, ao mesmo tempo, vemos a discussão ser encaminhada para uma tratativa que preza exemplos fenomênicos - como "cor" e "ponto no espaço visual" - na elucidação deste conceito.

A discussão sobre o requerimento da análise lógica nos Notebooks utiliza recorrentemente exemplos de proposições sobre partes da imagem visual do sujeito. A complexidade espacial é considerada também uma complexidade lógica e novamente Wittgenstein arrisca exemplos ao dizer que sempre pensou em pontos da imagem visual como objetos simples:

Mas como eu coloco o simples perante mim? Tudo que eu posso aqui dizer é sempre " $x$ ' tem significado". - Aqui está um grande mistério!

Como exemplos de simples eu sempre penso em pontos da imagem visual (assim como porções da imagem visual sempre me vêm à mente como típicos "objetos compostos").

A complexidade espacial também é complexidade lógica? Parece que sim! ${ }^{34}$

Como aponta Soutif ${ }^{35}$, o apelo a este tipo de exemplo pode sugerir que o requerimento da análise lógica é estabelecido em bases psicológicas ou psicofísicas, e não puramente lógicas.

Para conhecer um objeto é necessário que sejam conhecidas suas propriedades internas ( $\mathrm{T}$ 2.01231), e isto quer dizer que devemos nos atentar ao que nele há de essencial. Uma propriedade é interna caso seja impensável que seu objeto não a possua ( $\mathrm{T}$ 4.1221). O que há de essencial no objeto é a sua possibilidade de ocorrência em fatos atômicos ( $\mathrm{T}$ 2.011), i.e., sua forma ( $\mathrm{T}$ 2.0141). Sendo assim, pode-se dizer que se é uma explicação sobre a noção de objeto que estamos perseguindo, ela só pode ser concretizada se explicarmos o que é a forma de um objeto. Quanto a este ponto, Wittgenstein é categórico: espaço, tempo e cromaticidade são formas dos objetos (T 2.0251). Afirmações como esta podem, prima facie, servir de base para a defesa de que, na verdade, Wittgenstein não só fornece exemplos para objetos como estes últimos here used for such things as a colour, a point in visual space, etc: cf. also above. A word has no sense except in a proposition."(Wittgenstein and Lee, 1980, p. 120 [67].

34"Wie stelle ich mir aber das Einfache vor? Da kann ich immer nur sagen " $x$ ' hat Bedeutung". - Hier ist ein großes Rätsel!

Als Beispiele des Einfachen denke ich immer an Punkte des Gesichtsbildes. (Wie mir als typisch "zusammengesetzte Gegenstände" immer Teile des Gesichtsbildes vorschweben.)

Ist räumliche Zusammengesetztheit auch logische Zusammengesetztheit? Es scheint doch, ja!" (Wittgenstein, 1969, p. 45 [62])

${ }^{35} 2017$, p. 9 [54]. 
possuem natureza fenomênica. Esta abordagem marca uma visão fenomênica sobre o objeto tractariano, que deve ser entendida não como uma interpretação específica, mas qualquer interpretação que dê prevalência às observações que envolvem aspectos da experiência empírica.

Vemos que dois modos incompatíveis de encarar o objeto simples podem ser identificados na filosofia do primeiro Wittgenstein. De um lado, objetos são encontrados numa investigação lógico-filosófica a priori que identifica as condições que possibilitam o discurso significativo e prescinde de exemplos dados a posteriori. Do outro, exemplos fenomênicos aparecem como uma alternativa que viabiliza a exemplificação de proposições elementares e de objetos simples - o que de acordo com o próprio Tractatus só mostra que seguimos a triha errada. É preciso entender, portanto, por qual motivo Wittgenstein oferece, num trabalho filosófico e por isso totalmente contrassensual, as formas que permitem a exemplificação das proposições elementares que deveriam ser encontradas pelo cientista natural, não pelo filósofo.

As observações que tratam o objeto em termos fenomênicos motivam interpretações diversas. De posse das formas lógicas que caracterizam a substância, é possível fornecer a estrutura de fatos atômicos e, deste modo, exemplificar também proposições elementares. De acordo com Jacquette ${ }^{36}$, o aforismo 2.0251 sugere que combinações de objetos simples exemplificam a forma lógica de fatos atômicos e proposições elementares. Uma proposição elementar é interpretada como uma figuração que atribui a instanciação de um valor fenomênico num lugar e tempo determinados. Cada objeto simples possui uma das três formas que devem ocorrer concomitantemente em sua combinação, formando assim os elos da corrente que estruturam o fato atômico ( $\mathrm{T}$ 2.032). Construções do tipo C-S-T (cor-espaço-tempo) são predicações portadoras de valor de verdade completas em sua forma lógica mínima e exemplificam, desta maneira, as proposições elementares que figuram os fatos atômicos.

A independência da substância quanto àquilo que ocorre é comumente interpretada em termos de sua existência necessária. Objetos devem, como vimos, compor a forma fixa do mundo, e deste modo podem ser interpretados como existentes necessários que garantem que o mundo atual e um mundo possível compartilhem algo. Esta substancialidade pode ser interpretada nos seguintes termos: as formas dos objetos são espaço, tempo e cor, e são os objetos que compõem a forma fixa do mundo; isto significa que todo mundo possível deve compartilhar a forma C-S-T, na qual objetos são conectados por relações predicacionais lógicas primitivas na estrutura do fato atômico ${ }^{37}$.

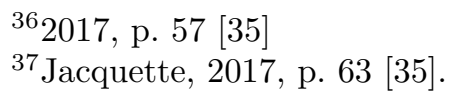


Outra passagem que corrobora a visão fenomênica ocorre nos aforismos 2.013-2.0131:

2.013 Cada coisa está como que num espaço de possíveis fatos atômicos. Esse espaço, posso concebê-lo vazio, mas não a coisa sem o espaço.

$2.0131 \mathrm{O}$ objeto espacial deve estar no espaço infinito. (O ponto do espaço é um lugar de argumento)

Não é preciso, por certo, que a mancha no campo visual seja vermelha, mas uma cor ela deve ter: tem à sua volta, por assim, dizer, o espaço das cores. O som deve ter uma altura, o objeto do tato, uma dureza, etc. ${ }^{38}$

Estes aforismos apresentam a ideia de que podemos conceber vazio o espaço de possíveis fatos atômicos no qual o objeto "está como que" colocado. A elucidação desta afirmação ocorre por meio de uma analogia que compara a relação mantida entre o objeto e seu espaço circundante com aquela que existe entre um item fenomênico e uma modalidade sensorial multidimensional específica $^{39}$. De acordo com Frascolla, devemos entender esta passagem da seguinte maneira:

The claim made in the pair of sections 2.013 and 2.0131 can be restated as follows: an object cannot be thought of apart from its possible combinations with other objects, i.e. apart from the set of states of affairs of which it is a constituent, even though it is conceivable that none of these states of affairs obtains, is a fact. ${ }^{40}$

O que está em jogo nos aforismos sob nossa consideração, de acordo com esta leitura, é a relação entre um objeto e um conjunto cujos membros são todos os fatos atômicos nos quais este pode ocorrer - neste caso, o seu espaço lógico.

Esta interpretação desafia o entendimento da substancialidade do objeto como sua existência em todos os mundos possíveis. Poder conceber vazio este espaço de situações possíveis significa dizer que mesmo que estas situações estejam prefiguradas na essência do objeto, elas são contingentes e podem, por isso, não ocorrer em alguma configuração possível dos fatos. Para que um objeto exista num mundo possível, o fato atômico no qual ele ocorre deve ser o caso neste mesmo mundo. Dizer que o espaço lógico de um objeto pode ser pensado vazio significa reconhecer que é perfeitamente possível que nenhuma das situações que constituem este espaço ocorra. Se isto for o caso, nenhum dos fatos atômicos ocorre em algum mundo possível e, deste modo, o objeto

\footnotetext{
${ }^{38}$ Wittgenstein, 2017, p. 131 (tradução modificada) [60].

${ }^{39}$ Soutif, 2013, p. 103 [55].

${ }^{40}$ Frascolla, 2005, p. $372[18]$.
} 
falha em existir neste mundo. Sendo assim, objetos não podem ser considerados existentes necessários ${ }^{41}$.

Segundo Frascolla, a melhor maneira de entender o aforismo 2.0251 é a partir de uma abordagem que considera objetos como partes qualitativas repetíveis, no sentido daquilo que Nelson Goodman ${ }^{42}$ chama de qualia. Um complexo visual concreto, sob esta perspectiva, é analisado em termos de três partes qualitativas constituintes: um tempo fenomênico, um lugar no campo visual e uma cor fenomênica. Estas qualidades fenomênicas repetíveis possuem caráter abstrato e são, desta forma, compatíveis com a divisão entre a esfera semântica dos objetos simples e a esfera empírica de complexos fenomênicos concretos. A ideia de que objetos são incolores (T 2.0232) pode ser explicada pela natureza abstrata dos qualia, pois uma propriedade material é dada pela configuração de objetos ( T 2.0231) e dizer que algo é colorido significa dizer que um qualia de cor compõe um complexo concreto $^{43}$. O nível último de existência diz respeito aos complexos concretos ou fatos atômicos que formam o mundo fenomênico. Objetos subsistem independentemente do que é o caso porque a existência é dada em termos de combinações variáveis de unidades repetíveis qualitativas fixas que não dependem logicamente de sua configuração. O cientista natural fala sobre aquilo que existe e neste sentido trata sobre algo dado a posteriori. Este tipo de existência não pode ser atribuído aos qualia, que existem independentemente do que é o caso e, por isso, são de certa forma anteriores à experiência empírica.

Esta explicação procura evitar a transgressão do princípio tractariano que divide questões lógico-filosóficas de considerações empíricas, mostrando que os qualia estão em um nível ontológico diferente dos fatos que constituem devido à sua natureza universal, repetível e multiplamente instanciável. Contudo, Se a conclusão de que espaço, tempo e cor são formas dos objetos não ocorre por meio de uma "intromissão" empírica, como explicar a identificação totalmente a priori destes conceitos? O fato de as formas dos objetos possuírem um caráter ontológico diferente daquele apresentado por um fato atômico parece não ser suficiente para justificar nossa chegada, calcada nos aspectos puramente apriorísticos da investigação filosófica, à categorias correspondentes a modalidades de nossa experiência sensível. Uma saída plausível para o choque existente entre a demanda de que a lógica tome conta de si mesma e a insistência no uso de exemplos fenomênicos é reconhecer que a postura de Wittgenstein era conflitante. Por mais que ele tenha enxergado a necessidade de uma separação entre a lógica e a sua aplicação, é inegável que sua concepção

\footnotetext{
${ }^{41}$ Frascolla, 2006, p. 76 [19].

${ }^{42} 1977$ [30].

${ }^{43}$ Frascolla, 2006, p. 78-80 [19]
} 
de linguagem pressupõe uma relação muito próxima entre esta última e a realidade que ela representa.

Uma abordagem fenomênica sobre o objeto possui recursos suficientes para defender que construções do tipo C-S-T exemplificam a estrutura de proposições elementares. O fato atômico é apresentado como uma localização espacial num dado momento possuindo uma determinada cor. De acordo com uma crítica feita por Frank Ramsey ${ }^{44}$, um tal entendimento sobre a construção do fato atômico acarreta um problema no tocante à tese de que as proposições elementares devem ser logicamente independentes umas das outras (T 5.134). A independência entre proposições elementares pode ser justificada pela necessidade de determinação completa do sentido, independentemente do valor de verdade de qualquer outra proposição. Se uma proposição elementar depende logicamente de uma outra, isto significa que a análise ainda não chegou ao fim e que, portanto, se tratava de uma proposição complexa. De acordo com o Tractatus, uma contradição ou tautologia não pode ser produto lógico de duas proposições elementares:

6.3751 Que, por exemplo, duas cores estejam ao mesmo tempo num lugar do campo visual é impossível e, na verdade, logicamente impossível, pois a estrutura lógica das cores exclui essa hipótese.

(É claro que o produto lógico de duas proposições elementares não pode ser nem uma tautologia nem uma contradição. O enunciado de que um ponto no campo visual tem ao mesmo tempo duas cores diferentes é uma contradição). ${ }^{45}$

O enunciado " $A$ é vermelho e $A$ é azul", no qual $A$ significa uma dada localização espacial num momento determinado, é, deste modo, um exemplo de contradição. As proposições que constituem esta conjunção são, com efeito, instâncias claras de construções C-S-T que, de acordo com o aforismo 2.0251, exemplificariam a forma de proposições elementares. Entretanto, o enunciado "A é vermelho" não pode ser um exemplo de proposição elementar, pois o produto lógico de duas proposições elementares não pode ser uma contradição. Como aponta Ramsey ${ }^{46}$, dizer que "este ponto é vermelho e azul" é uma contradição implica reconhecer que os conceitos "azul" e "vermelho", que deveriam ser simples, são na verdade complexos e formalmente incompatíveis. Como consequência da explicação fornecida no aforismo 6.3751, proposições elementares não podem ser equiparadas a construções C-S-T.

Esta crítica pode ser interpretada como a fonte de uma importante mudança na abordagem filosófica de Wittgenstein ${ }^{47}$. No Tractatus, a necessidade

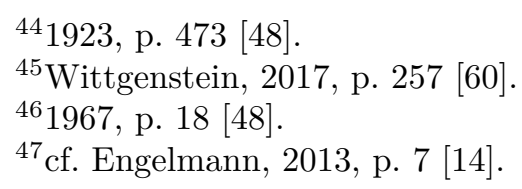


da análise lógica de enunciados em proposições elementares é dada a priori e assim sabemos de antemão que estas últimas devem existir. O problema apontado por Ramsey mostra que existe uma incompatibilidade formal entre proposições consideradas elementares à vista dos exemplos de natureza fenomênica utilizados para as formas dos objetos. Efetivar a análise lógica, que é somente pressuposta no Tractatus, apresenta-se como um caminho viável na busca de uma solução a este problema. Para fazer isto, contudo, Wittgenstein deverá abrir mão da aprioricidade da investigação filosófica e virar sua atenção para os fenômenos. Esta atitude, que aparece de maneira escamoteada e vacilante em seus primeiros escritos, é defendida explicitamente em seu retorno à filosofia no fim dos anos 20:

Now we can only substitute a clear symbolism for the unprecise one by inspecting the phenomena which we want to describe, thus trying to understand their logical multiplicity. That is to say, we can only arrive at a correct analysis by, what might be called, the logical investigation of the phenomena themselves, i.e., in a certain sense a posteriori, and not by conjecturing about a priori possibilities. ${ }^{48}$.

A investigação lógica não diz mais respeito a conjecturas sobre possibilidades a priori e deve, diferentemente do que apregoa o aforismo 5.551 do Tractatus, partir da análise a posteriori dos fenômenos neles mesmos.

É necessário distinguir duas questões. A primeira diz respeito à compatibilidade da visão fenomênica com a filosofia do primeiro Wittgenstein. Quanto a este ponto, os exemplos abordados até agora não deixam dúvidas de que alguns aforismos se deixam interpretar nos moldes de uma concepção fenômenica sobre as natureza do objeto e de sua forma. Sabemos, contudo, que estes aspectos ganham centralidade somente a partir de 1929 e que no Tractatus estas ideias não são totalmente desenvolvidas. Apesar de esta visão ser compatível e poder ser desenvolvida a partir de certas observações, é preciso reconhecer que a necessidade da investigação a priori aparece de maneira explícita, como um princípio da investigação filosófica. Este conflito é trazido à tona, entre outros fatores, pelas críticas de Ramsey, que mostram a necessidade da concretização da análise lógica somente postulada no Tractatus. Isto no leva à segunda questão, que deve se preocupar com a efetiva posição de Wittgenstein sobre a noção de objeto. Podemos dizer que esta posição incorpora dois aspectos que se revelarão conflitantes, forçando mudanças durante o desenvolvimento da filosofia wittgensteineana.

${ }^{48}$ Wittgenstein, 1929, p. 163 [60]. 


\section{3}

\section{Conflito entre duas demandas}

O conflito que se apresenta entre demandas holistas e atomistas no Tractatus já é conhecido na literatura. Silva ${ }^{49}$, por exemplo, evidencia a incompatibilidade de duas teses tractarianas: por um lado, uma proposição elementar deve ser logicamente independente de outras ( $\mathrm{T}$ 5.134); por outro, todo o espaço lógico já deve ser dado por meio de uma proposição (T 3.42). Aspectos holistas são favorecidos explicitamente por Wittgenstein ${ }^{50}$ após o seu retorno à filosofia em 1929, como no exemplo da tese de que sentenças significativas devem ser comparadas à realidade como sistemas proposicionais, não isoladamente - o que vai de encontro à sua ideia anterior de que proposições elementares possuem seu significado de maneira independente.

Raízes deste holismo podem ser identificadas no Tractatus, na comparação que ocorre nos aforismos 2.013-2-0131 entre objetos e elementos como 'ponto no espaço visual'. O ponto desta analogia é, de acordo com Soutif ${ }^{51}$, reconhecer o objeto como uma localização ou conjunto de coordenadas no espaço de todos os possíveis fatos atômicos no qual ele pode ocorrer. Esta posição representa, contudo, um entrave para a tese de que objetos são ultimamente simples. Isto ocorre porque se o objeto deve ser entendido como uma localização num sistema de coordenadas, ele deve ser dotado de certa complexidade formal, pois num sistema como este a localização de um ponto depende logicamente de todos os outros. O mesmo problema quanto à simplicidade ocorre na interpretação de Frascolla sobre estes aforismos. Como foi visto, sua crítica da substancialidade do objeto depende de sua interpretação do trecho 2.0132.0131, que observa que o espaço lógico, considerado como o conjunto dos fatos nos quais o objeto pode ocorrer ${ }^{52}$, já deve estar prefigurado em sua essência e não pode ser pensado sem ele. Este espaço formal que circunda o objeto é, desta forma, um complexo formalmente constituído por vários fatos possíveis.

A ideia de que o espaço lógico deve estar conectado essencialmente à natureza mesma do objeto, não é, contudo, corroborada pelo Tractatus. O termo "espaço lógico" [logischen Raum] aparece explicitamente em seis aforismos do livro e em nenhum deles o termo ocorre relacionado ao objeto. Em todos eles, contudo, encontramos os termos de uma relação com fatos ou

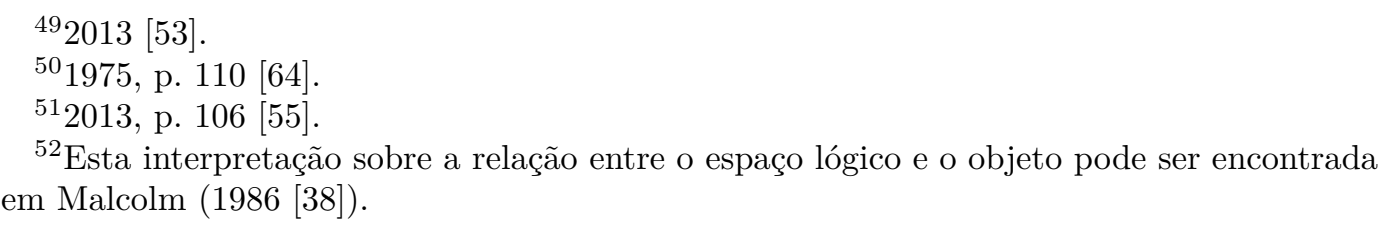


proposições $^{53}$. De fato, é a proposição que determina um lugar no espaço lógico ( T 3.4) - não o nome, cujo referente é o objeto simples. Entre as duas esferas há uma importante diferença: o nome mantém uma relação referencial com objetos enquanto a proposição mantém uma relação de afiguração com fatos ${ }^{54}$. A passagem que sustenta a relação pretendida é o aforismo 2.013, de acordo com o qual o objeto está colocado num espaço de possíveis fatos atômicos, o qual pode ser considerado como o espaço lógico. Este aforismo é logicamente subordinado ao 2.01, que afirma que o fato atômico é uma combinação de objetos.

A série de aforismos que se segue apresenta a visão de Wittgenstein sobre o vínculo do objeto com o fato atômico. As possibilidades de ocorrência de objetos em fatos atômicos constituem a sua natureza, de tal maneira que para conhecê-lo é preciso conhecer cada uma destas possibilidades. Isto significa que não é necessário conhecer as propriedades externas destes elementos, mas tão somente suas propriedades internas, i.e., propriedades essenciais, sem as quais o objeto não pode ser pensado. A possibilidade da ocorrência de um objeto em fatos atômicos é a forma do objeto (T. 2.0141). Com isto não se quer dizer que existe um certo conjunto de fatos atômicos possíveis que configura seu espaço lógico circundante, mas sim que todo objeto possui, devido à sua forma, sua capacidade intrínseca de conexão com outros objetos ${ }^{55}$. A analogia colocada nos aforismos 2.013-2.0131 elucida a relação que existe entre o objeto e a sua forma.

A afirmação de que o espaço de possíveis fatos atômicos que circunda o objeto pode ser concebido vazio está relacionada com a ideia de que a substância do mundo é forma e conteúdo ( $\mathrm{T}$ 2.025). Dizer que o espaço que circunda o objeto pode ser concebido vazio significa dizer que a forma de um objeto pode ser concebida independentemente de um conteúdo particular e que este último, por sua vez, não pode ser pensado separado de sua forma. Neste sentido, os exemplos fenomênicos são utilizados como base de comparação porque é isto que ocorre se pensarmos em algo como uma mancha no campo visual - é possível conceber a modalidade sensorial da cor sem a necessidade de nenhum exemplo específico. Saber que algum $x$ é uma cor permite, por exemplo, que reconheçamos a impossibilidade da construção " $x$ é salgado", sem a necessidade de saber se esta cor é azul ou vermelha. O ponto da analogia é, deste modo, reconhecer que nenhum objeto pode ser concebido fora de seu espaço de possíveis ocorrências em fatos atômicos, i.e., sua forma.

A posição do primeiro Wittgenstein sobre o objeto é resultado da

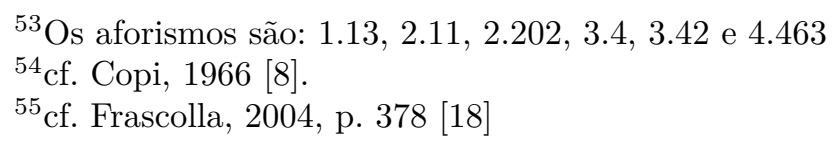


admissão de demandas conflitantes. Entender o objeto significa, deste modo, entender os termos de um conflito entre atomismo e holismo. A demanda atomista sobre o objeto no Tractatus exige que este seja destituído de qualquer complexidade para que o sentido de uma proposição não dependa da verdade de outra proposição. Entender como a demanda da simplicidade está relacionada à ideia de análise é uma questão que necessita de atenção, pois a análise decomposicional, apesar de ser pressuposta, não é efetivada pelo primeiro Wittgenstein. A mesma análise que desvela a simplicidade dos objetos deve identificá-lo como elemento essencialmente constituinte de um fato atômico, mas esta última demanda compromete a simplicidade e aproxima a abordagem wittgensteineana a uma posição holista. Interessa-nos, deste modo, investigar as razões que levam à defesa destes postulados, proporcionando assim um esclarecimento sobre a gênese da noção de objeto.

A contradição que configura o objeto tractariano é reconhecida na ideia de que ele é, ao mesmo tempo, dependente e independente ( $\mathrm{T}$ 2.0122). É dependente porque está essencialmente conectado ao nexo do fato atômico e não pode ocorrer fora dele. É independente porque pode ocorrer em qualquer fato atômico cuja possibilidade seja admitida pela sua forma. Afirmar que o objeto é indissociável de sua forma é o mesmo que dizer que este não pode ser pensado sem aquela e não pode ser concebido fora de sua possibilidade de conexão com outros. Se substituirmos os termos ontológicos por termos linguísticos, esta afirmação será equivalente ao Princípio do Contexto, de acordo com o qual um nome só possui significado no nexo proposicional, em sua conexão com outros nomes ( $\mathrm{T}$ 3.3).

A existência dos objetos é justificada pelo argumento da substância, no esforço de manter a bipolaridade como marca essencial do discurso significativo, possibilitando assim a visão figurativa sobre a linguagem. A indecomponibilidade da substância garante o fim da análise lógica, evitando que a determinação do sentido proposicional seja prejudicada. A ideia de que objetos são análogos a itens fenomênicos é utilizada na elucidação da consequência ontológica de outro aspecto essencial da linguagem. Nomes devem sua significatividade ao contexto de uma proposição elementar e os objetos que são seus referentes só existem ao lado de sua forma lógica. A simplicidade da substância é uma demanda atomista que estabelece a independência do objeto em termos da possibilidade de sua ocorrência em todos os fatos atômicos. O objeto é, contudo, ontologicamente dependente de sua ocorrência no fato atômico, pois ele não pode existir sem a incorporação da possibilidade desta ocorrência.

Para esclarecer a relação existente entre a forma dos objetos e o Princípio do Contexto, é preciso entender melhor o papel de cada uma destas noções 
no aparato conceitual tractariano. A ideia de uma forma lógica ocorre recorrentemente no Tractatus, porém é difícil precisar se estas ocorrências dizem respeito ao mesmo conceito. Wittgenstein discorre sobre a forma dos objetos, que é tomada como a possibilidade de sua ocorrência em fatos atômicos. Outras ocorrências da noção de forma, no entanto, não fazem referência a objetos. Um exemplo pode ser visto no aforismo 2.18, no qual fala-se sobre a forma da realidade [Form der Wirklichkeit] (T 2.18). Como "realidade" e "objeto" são conceitos claramente distintos, faz sentido perguntar se "forma dos objetos" e "forma da realidade" são também diferentes em algum aspecto.

O uso tractariano do Princípio do Contexto deve ser melhor entendido com o resgate da influência fregeana sobre o trabalho do primeiro Wittgenstein. Este ditame desempenha um papel significativo na filosofia fregeana como um princípio heurístico reclamado com a justificativa de eliminar ambiguidades provenientes de certas posições filosóficas. O objetivo de evitar estes malentendidos é, com efeito, o mote geral seguido pelo Tractatus. A comparação entre os dois usos é importante porque é a inobservância de um aspecto importante para Frege que acarreta o holismo do conceito de forma dos objetos. Para que a relação entre o princípio e a noção de forma seja clarificada, é preciso que identifiquemos as nuances conceituais que motivam a distinção entre diferentes tipos de forma no Tractatus. A partir disso será possível entender melhor como o objeto tractariano acaba incorporando uma demanda holista em sua formulação, acarretando um conflito interno na primeira filosofia de Wittgenstein. 


\section{3}

\section{Formas no Tractatus}

De acordo com o primeiro Wittgenstein, a filosofia é a doutrina da forma lógica das proposições científicas ${ }^{1}$. A ideia de que as proposições escondem sua forma lógica, remetida a Russell ( $\mathrm{T}$ 4.0031), é incorporada à concepção wittgensteineana. A verdadeira forma pode ser distinguida de uma forma apenas aparente graças ao trabalho analítico. A linguagem disfarça o pensamento como roupas disfarçam um corpo e não deixam que sua verdadeira forma seja observada (T 4.002). Como foi visto, a existência dos objetos simples está de alguma maneira contida na análise lógica, que deve também fornecer a estrutura última da proposição. Substância, forma e análise são três conceitos que aparecem intimamente interligados na intricada trama teórica tractariana. A simplicidade da substância garante a determinação do sentido e sua existência permite que a análise lógica tenha um fim e que a forma lógica da proposição seja lograda. Esta curta afirmação, contudo, depende de vários pressupostos que precisam de esclarecimento. No Tractatus, a primeira aparição da noção de forma se dá no aforismo 2.0141, no qual esta é apresentada como a possibilidade da ocorrência de um objeto em fatos atômicos. A forma fixa do mundo, que permite que um mundo imaginário compartilhe algo com o mundo real, é constituída pelos objetos (T 2.022-3). Como a substância é forma e conteúdo (T 2.025), a conclusão imediata é a de que esta forma fixa diz respeito à forma dos objetos aludida no 2.0141 .

De fato, objetos constituem uma unidade com o fixo e o subsistente ( $\mathrm{T}$ 2.027) e é a sua existência que possibilita a forma fixa do mundo ( $\mathrm{T}$ 2.026). Isto não significa, no entanto, que as noções de forma dos objetos e forma fixa do mundo sejam equivalentes. A capacidade de aparição no fato atômico é a forma dos objetos. A ideia de uma forma fixa diz respeito ao mundo, e o mundo é a totalidade dos fatos, não das coisas (T 1.1). Fatos atômicos são constituídos por objetos e, enquanto tais, são essencialmente diferentes destes últimos. A capacidade de combinação, considerada marca essencial do objeto, é o que torna possível a estrutura de um fato ( $\mathrm{T}$ 2.033). Esta estrutura deve ser entendida como uma determinada maneira na qual objetos encontram-se efetivamente vinculados no fato atômico ( $\mathrm{T} 2.032)^{2}$. Trata-se, deste modo, de duas possibilidades diferentes. A primeira envolve a possibilidade, inerente ao objeto enquanto tal, de ocorrer num fato; a segunda

\footnotetext{
${ }^{1}$ Wittgenstein, 1969, p. 106 [62].

${ }^{2}$ cf. Friedlander, 2001, p. 37 [29].
} 
diz respeito à possibilidade de que um dado fato atômico apresente uma configuração ou estrutura específica. A segunda possibilidade repousa sobre a primeira, i.e., a possibilidade da estrutura de um fato atômico é garantida pela capacidade combinatorial do objeto, i.e., sua forma. Esta capacidade, por seu turno, não depende de nada a não ser da essência mesma da substância.

A partir do aforismo 2.1 Wittgenstein coloca com mais ênfase o tópico da teoria da figuração, abordado antes disso apenas uma vez no argumento da substância. Deparamo-nos novamente com as noções de forma e estrutura durante a exposição subsequente a este aforismo :

2.15 Que os elementos da figuração estejam uns para os outros de determinada maneira representa que as coisas assim estão umas para as outras.

Essa vinculação dos elementos da figuração chama-se sua estrutura; a possibilidade desta, sua forma de afiguração. ${ }^{3}$

Como anteriormente, a ideia de forma está novamente conectada à uma possibilidade. Vale a pena notar, contudo, que os termos da explicação apresentada neste aforismo são ligeiramente diferentes daqueles enunciados anteriormente nos aforismos 2.032-3. A forma é considerada como possibilidade de uma estrutura nos dois casos, mas no primeiro a forma dos objetos é tomada como a possibilidade para a estrutura de um fato atômico, enquanto no segundo a forma de afiguração é a possibilidade da estrutura de uma figuração.

É compreensível, sob estas circunstâncias, a tendência em considerar exemplos de natureza fenomênica na elucidação do objeto. A forma dos objetos é comparável ao "espaço" que circunda uma mancha no campo visual e permite sua conexão com as demais formas do espaço e do tempo em estruturas C-S-T, estas últimas resultado da concatenação dos objetos. Em que sentido, contudo, a estrutura de uma figuração é comparável à estrutura de um fato atômico? Até então, sabemos que o fato atômico é uma combinação de objetos simples que compõe o nível mais básico daquilo que pode ou não existir. Devemos saber, deste modo, o que é uma figuração, estabelecendo assim uma base de comparação entre os dois conceitos. A respeito disso, Wittgenstein afirma:

2.14 A figuração consiste em estarem seus elementos uns para os outros de uma determinada maneira.

2.141 A figuração é um fato [Tatsache]. ${ }^{4}$

Um modo plausível de conceber a figuração como um fato é entender que os signos linguísticos que representam o mundo estão, eles mesmos, situados

${ }^{3}$ Wittgenstein, 2017, p. 137 [60].

${ }^{4}$ Wittgenstein, 2017, p. 137 [60]. 
no mundo. A figuração é um fato, assim como uma frase escrita numa folha de papel ou uma transmissão em código morse. No entanto, observada a distinção tractariana entre fatos [Tatsachen] e fatos atômicos [Sachverhalten], esta passagem pode ser lida de uma maneira diferente. Dizer que uma figuração é um fato equivale a dizer que sua estrutura é constituída pelas estruturas de dois ou mais fatos atômicos $(\mathrm{T} 2.034)^{5}$. A forma dos objetos é a possibilidade da estrutura de um fato atômico, enquanto a forma de afiguração é a possibilidade da estrutura de um fato. Os elementos da figuração estão conectados de uma certa maneira, i.e., apresentam uma certa estrutura, e isto representa que as coisas, no fato atômico, estão conectadas da mesma maneira. Uma figuração é um fato composto por ao menos dois fatos atômicos que compartilham o mesmo modo de combinação. A possibilidade desta equiparação estrutural é chamada de forma de afiguração (T 2.151).

É importante notar que apesar de a figuração ser ela mesma um fato, aquilo que ela representa é, por sua vez, não o fato atômico em si, mas a possibilidade de sua existência ou inexistência ( $\mathrm{T}$ 2.201). Uma proposição elementar é composta pela combinação imediata de nomes próprios, cuja função é a de se referir a objetos simples. A existência de objetos é postulada no argumento da substância de modo a manter a possibilidade da composição de figurações que é prejudicada caso o sentido de uma proposição dependa da verdade de outra proposição. O sentido veiculado pela figuração é uma representação da realidade que não depende da verdade ou falsidade de nenhuma proposição, mas da própria forma de afiguração (T 2.22). Em outras palavras, o sentido de uma proposição depende somente da possibilidade de que dois fatos atômicos compartilhem a mesma estrutura.

A forma de afiguração desempenha um papel específico na teoria da representação apresentada pelo primeiro Wittgenstein. Sua elucidação filosófica situa o sentido proposicional no encontro de duas estruturas complexas ligadas por uma relação de afiguração. A forma de afiguração é aquilo que um fato [Tatsache] deve ter em comum com aquilo que é figurado para que seja considerado uma figuração da realidade ( $\mathrm{T}$ 2.16-7), possibilitando a relação de afiguração que consiste na coordenação entre os elementos da figuração e os objetos do fato atômico ( $\mathrm{T}$ 2.1514). O que está em jogo nessa relação repre-

${ }^{5}$ Esta interpretação pressupõe que Sachverhalte são distintos de Tatsachen por uma questão de complexidade. Além do aforismo 2.034, uma explicação de Wittgenstein a Russell sobre a natureza do Sachverhalt corrobora esta abordagem (cf. Wittgenstein e McGuinnes, 2008, p. 96 [68]). Um Tatsache é, deste modo, um complexo de Sachverhalte. Existe, contudo, ao menos outra interpretação possível, estimulada pela leitura de Stenius (1964 [57]), sugerindo que esta distinção separa o que é possível (Sachverhalt) do que é real ou atual (Tatsache). Para uma discussão sobre estas diferentes interpretações, ver Edgar Marques (1990 [40]) e José Oscar Marques (1991 [41]). 
sentacional é a própria conexão entre a proposição e a realidade ( $\mathrm{T}$ 2.1511). Esta conexão baseia o sentido proposicional e não diz respeito ao estabelecimento de um valor de verdade, pois este é efetivado através da comparação do sentido da figuração com a realidade (T 2.21). É por isso que somos perfeitamente capazes de entender o sentido de uma proposição sem saber se ela é ou não verdadeira ( $\mathrm{T}$ 4.024) - este sentido não é algo, não é ele mesmo um fato, mas uma possibilidade de existência e não existência de fatos atômicos. Esta possibilidade é apenas a projeção resultante da relação de representação que se mantém entre linguagem e realidade.

$\mathrm{O}$ argumento da substância condiciona a possibilidade de figurações à existência de objetos. Existem dois modos de aproximação entre a figuração e a realidade, referentes às noções de sentido e verdade. A conexão entre linguagem e mundo proporcionada pela relação afiguradora origina o sentido da figuração. Uma segunda aproximação diz respeito ao estabelecimento de seu valor de verdade, que ocorre através da comparação entre o sentido da figuração e uma situação no mundo. Para que uma proposição tenha valor de verdade, é preciso que possua antes um sentido a ser comparado à realidade; o estabelecimento do sentido, por sua vez, independe desta comparação e pressupõe apenas a possibilidade de que uma proposição elementar e um fato atômico compartilhem a mesma estrutura. A relação de afiguração só é possível graças à forma de afiguração, que permite a coordenação entre os elementos da figuração e as coisas. Sem a substância a possibilidade de figurações encontra um entrave, pois a possibilidade de correspondência entre nome próprio e objeto garante a determinação do sentido proposicional sem a necessidade do apelo à verdade de outra proposição, evitando assim o regresso sentidoverdade. É neste sentido que o princípio da substituição de objetos por sinais baseia a possibilidade da proposição ( $\mathrm{T}$ 4.0312).

É recorrente, no discorrer sobre a ideia de forma, sua ocorrência ao lado da noção de possibilidade. A primeira possibilidade apresentada caracteriza a forma dos objetos, tomada como a capacidade de ocorrência em fatos atômicos. Para que algo seja um objeto, é necessário que sua combinação com outros objetos seja possível. Esta possibilidade, por seu turno, torna possível o arranjo estrutural de objetos que constitui o fato atômico. Se objetos devem poder ocorrer em fatos atômicos, então é possível que estes fatos possuam uma estrutura, um modo de combinação específico. Neste sentido, a forma entendida em sua acepção modal de possibilidade de ocorrência em fatos atômicos possui também uma função transcendental de possibilitar a estrutura destes mesmos fatos. Com isso somos levados à terceira possibilidade, qual seja, a de que o fato atômico se encontre estruturado da mesma maneira 
que a proposição elementar. A coordenação entre nome e objeto baseia a relação de representação que se mantém entre a linguagem e realidade, a partir da qual ocorre a projeção do sentido proposicional. A figuração é um fato cuja estrutura é formada pelas estruturas de fatos atômicos que encontramse configurados da mesma maneira. A forma de afiguração é a possibilidade desta estrutura, que pressupõe não apenas a conexão dos objetos no fato atômico como também uma relação de afiguração que conecta dois complexos estruturalmente idênticos.

Este breve exame sobre a teoria da figuração possibilita a identificação de distinções importantes entre dois tipos de forma, revelando também o modo pelo qual estes dois conceitos encontram-se conectados. Sendo um fato, a figuração é formada pelas estruturas de fatos atômicos e a possibilidade destas últimas é, deste modo, pressuposta pela primeira. A possibilidade de ocorrência do objeto em um fato atômico deve estar gravada em sua natureza. Se objetos podem ocorrer em fatos atômicos, então é possível que estes últimos possuam suas respectivas estruturas, resultantes da concatenação dos primeiros. Se a estrutura do fato atômico é possível, então também é possível que dois fatos apresentem a mesma estruturação. Quando isso ocorre, esses fatos são conectados por uma relação de representação que enseja a projeção do sentido de uma figuração. A forma dos objetos é, deste modo, pressuposta na formulação da noção de forma de afiguração. O contrário, contudo, não acontece - a forma dos objetos não depende da forma de afiguração e não pressupõe a relação de afiguração que articula a coordenação dos elementos na figuração.

Figuração e figurado devem possuir algo de idêntico para que um seja a figuração do outro ( $\mathrm{T}$ 2.161) e existem ao menos duas maneiras pelas quais a realidade pode ser figurada. A forma de afiguração é aquilo que a figuração deve ter em comum com a realidade para que possa figurá-la de uma maneira particular (T 2.17). Para representar um objeto espacial, a figuração deve compartilhar com este último a forma do espaço, e o mesmo vale para qualquer outro aspecto da realidade que se deixa figurar ( T 2.171). Toda figuração é, contudo, também uma figuração lógica e por isso ela pode figurar a totalidade dos fatos (T 2.19). A figuração representa tanto um aspecto particular da realidade como a sua totalidade, por meio de sua forma lógica (T 2.18). A forma de afiguração é a possibilidade de que ao menos dois complexos compartilhem a mesma configuração, permitindo que seus elementos correspondam uns aos outros. Para figurar a realidade como um todo a figuração deve compartilhar o modo de combinação de seus elementos com a totalidade dos fatos.

Podemos constatar uma distinção adicional no interior do conceito de 
forma de afiguração que identifica duas maneiras pelas quais a figuração desempenha seu papel representacional. Nem toda figuração é cromática ela pode ser sonora, temporal ou espacial - mas todas as figurações são lógicas (T 2.182). Quando a forma de afiguração equivale à forma lógica, a figuração é chamada figuração lógica ( $\mathrm{T}$ 2.181). O conceito de forma lógica nos leva, desta maneira, direto a um outro conceito importante, pois a figuração lógica dos fatos é o que Wittgenstein chama de pensamento [Gedanke] (T 3). Como pode ser observado, as noções de forma dos objetos, forma de afiguração e forma lógica desempenham papéis diferenciados na elaboração de diferentes conceitos tractarianos. Uma explicação sobre apenas um desses conceitos não é suficiente para dar conta de todos eles. Esta distinção proporciona a identificação dos aspectos específicos que envolvem a explicação sobre a noção de forma dos objetos e diferenciam-na de outras referências à ideia de forma que ocorrem durante o Tractatus.

Argumentei anteriormente que a analogia dos aforismos 2.013-2.0131 não envolve o conceito de espaço lógico, mas discorre sobre a relação que existe entre o objeto e a sua forma. A analogia fala, de fato, de um "espaço" de possíveis fatos atômicos que circunda o objeto, o que sugere a interpretação de que se trata do espaço lógico tractariano. Ao seguir esta sugestão, uma pergunta ocorre naturalmente: como se dá a relação entre o espaço lógico e o objeto? A explicação, contudo, não é indicada em nenhuma das discussões sobre a ideia de espaço lógico no Tractatus. A ideia de uma forma lógica de afiguração aparece como o meio pelo qual uma figuração pode representar o mundo, que é a totalidade dos fatos no espaço lógico. Esta noção, diferentemente da forma dos objetos, encontra-se explicitamente conectada ao conceito de espaço lógico.

A proposição, que é a expressão linguística sensivelmente perceptível de uma figuração lógica (T 3.1), deve fornecer de antemão todo o espaço lógico, este último determinado pela armação lógica que envolve a figuração (T 3.42). O espaço de possíveis fatos atômicos mencionado no aforismo 2.013 não está ao redor da figuração, mas do objeto. O que permite que uma figuração percorra todo o espaço lógico e represente a totalidade dos fatos é a forma lógica de afiguração. A forma lógica depende somente da natureza da proposição e corresponde a um protótipo lógico (T 3.315), uma armação lógica que ajuda a proposição a descrever completamente a realidade ( $\mathrm{T}$ 4.023). A forma dos objetos diz respeito a um aspecto essencial da substância e os representantes linguísticos dos objetos são os nomes próprios. Um nome não é uma figuração da coisa nomeada - como a proposição é uma figuração de uma situação pois uma única palavra não pode ser verdadeira ou falsa e tampouco pode 
expressar o pensamento que concorda ou não com a realidade ${ }^{6}$. Os conceitos de forma dos objetos e forma lógica de afiguração pertencem, deste modo, a âmbitos distintos.

A substância é forma e conteúdo e a forma dos objetos é sua propriedade interna e, portanto, essencial. A distinção entre forma e conteúdo ocorre novamente na explicação tractariana sobre a natureza do sentido proposicional. A proposição é colocada no limiar da relação projetiva que se mantém entre um signo proposicional, por meio do qual o pensamento é expresso, e o mundo ( T 3.12). Wittgenstein chama as partes que caracterizam o sentido de uma proposição, assim como a proposição ela mesma, de expressão [Ausdrück]; esta última assinala, por sua vez, uma forma e um conteúdo (T 3.31). A investigação sobre a noção de expressão e sua relação com as ideias de forma e conteúdo configuram um passo importante na elucidação das diferenças entre noções de forma no Tractatus. A centralidade deste exame é acentuada devido ao desenvolvimento tractariano do Princípio do Contexto, que aparece diretamente relacionado à estes conceitos. Veremos que é possível interpretar o princípio de modo a justificar a transformação do nome em uma variável proposicional. Para entendermos o que está em jogo nessa discussão, examinaremos a maneira pela qual Frege utiliza seu Princípio do Contexto com o objetivo de fornecer uma base de comparação entre sua posição e a do primeiro Wittgenstein. Deste modo será possível entender o que está em jogo nos conceitos de forma e conteúdo de uma expressão, assim como avaliar como o Princípio do Contexto dá lugar à noção de forma dos objetos.

\section{1}

\section{Frege, Wittgenstein e o Princípio do Contexto}

Na introdução aos Grundlagen der Arithmetik ${ }^{7}$ Frege apresenta os três princípios metodológicos básicos de sua investigação:

Nesta investigação ative-me firmemente aos seguintes princípios: deve-se separar precisamente o psicológico do lógico, o subjetivo do objetivo; deve-se perguntar pelo significado das palavras no contexto da proposição e não isoladamente; não se deve perder de vista a distinção entre conceito e objeto. ${ }^{8}$

Os dois primeiros princípios estão intimamente relacionados, pois a não observância do segundo pode levar à admissão de figuras mentais como significados

${ }^{6}$ Wittgenstein, 1969 , p. 8-9

${ }^{7}$ Esta obra foi publicada originalmente em 1884 [20]. Doravante, utilizaremos a abreviação "Grundlagen" nas menções a este livro.

${ }^{8}$ Frege, 1974, p. 208 [21]. 
das palavras. A discussão que antecede a primeira ocorrência do princípio investiga a natureza dos números. O Princípio do Contexto fornece os recursos necessários para a tarefa de análise e leva à introdução de extensões para conceitos $^{9}$. A necessidade do princípio surge da constatação de ambiguidades decorrentes de posições psicologistas sobre a noção de número.

A reflexão de Frege, inicialmente, aborda a ideia de acordo com a qual uma unidade [Einheit] é cada uma das coisas que são enumeradas. A forma gramatical da palavra "um" influencia a ideia de que se trata de uma propriedade e a unidade pode ser concebida, deste modo, como a caracterização de um objeto. Contudo, argumenta Frege, se a unidade é uma propriedade, todas as coisas devem possuí-la - o que torna sua atribuição a qualquer objeto incompreensível. Há uma relação entre o conteúdo conceitual veiculado por uma propriedade e os objetos aos quais ele pode ser aplicado. Se um predicado não adiciona nada à descrição do sujeito, i.e., se por meio dele não é possível distinguir um objeto de outros, então seu conteúdo conceitual é nulo. Outro problema apontado por Frege é o fato de o predicado "um" não ser inteligível caso ocorra isoladamente. É possível combinar os enunciados "Sólon é sábio" e "Tales é sábio", obtendo assim a frase "Sólon e Tales são sábios". Apesar de ambos os sujeitos compartilharem a pretensa propriedade da unidade, a sentença "Sólon e Tales são um" não pode ser construída da mesma maneira. Quando descritos conjuntamente numa frase plural, Sólon e Tales não são um, mas dois ${ }^{10}$.

Esta crítica fregeana é "um exemplo de elucidação categorial sobre a natureza do número 'um' centrada na análise de possíveis ocorrências de sua expressão em sentenças típicas" ${ }^{11}$. A conclusão é a de que a palavra "unidade" é só outro termo para designar uma coisa, pois todo objeto pode ser tomado como "um". Frege argumenta contra uma definição do conceito de número em termos de um processo de abstração. Neste processo as características que distinguem duas coisas são ignoradas, com o objetivo de tornar idênticas coisas que antes eram diferentes. Dada a inviabilidade da identificação da unidade como uma propriedade, é preciso entender se a identidade é somente atribuída aos objetos ou se eles são, neles mesmos, realmente idênticos. Segundo Frege, duas coisas nunca são completamente idênticas, apesar de podermos identificar aspectos comuns entre dois objetos. A abstração não fornece o conceito de número das coisas abstraídas, mas um conceito geral que se aplica igualmente aos objetos considerados:

\footnotetext{
${ }^{9}$ Ricketts, 2010, p. 199 [50].

${ }^{10}$ Frege, 1974, p. 233-4 [21].

${ }^{11}$ Ruffino, 1990, p. 26 [51].
} 
Se ao examinar um gato branco e um preto, por exemplo, ignoro as propriedades pelas quais se distinguem, obtenho algo como o conceito "gato". [...] Também, se eu não pensar nas cores, ou me propuser a não tirar nenhuma conclusão apoiado em sua diferença, os gatos não se tornarão incolores e permanecerão tão diferentes quanto já eram. O conceito "gato", obtido por abstração, de fato não contém mais as particularidades, mas é precisamente por isso apenas um. ${ }^{12}$

O conceito "gato", que une dois gatos particulares distintos, é o resultado do processo de abstração daquilo que faz dois gatos particulares diferentes. Não é possível, a partir deste processo, tornar idênticas coisas distintas, pois seu resultado é uma coisa só - um só conceito satisfeito por dois objetos, que permanecem diferentes.

Para que coisas possam ser enumeradas é preciso que elas sejam distinguíveis umas das outras. A abordagem que define números como unidades é identificada em grandes nomes da tradição filosófica, como Locke e Leibniz ${ }^{13}$. A ideia de que unidades podem ser distintas acarreta, contudo, confusão conceitual. Frege aponta que conceber o número como uma anexação, conjunto ou pluralidade de unidades requer a conjunção de duas propriedades contraditórias: distinguibilidade e identidade. Como consequência, tomar números como resultado do ajuntamento de unidades é algo sem sentido. Se a unidade é o resultado de um processo de abstração que elimina tudo aquilo que é distinguível entre objetos, é difícil entender como o conceito de número, que pressupõe distinguibilidade, pode ser obtido nestes termos. As confusões filosóficas que envolvem a ideia de unidade são incitadas pela dificuldade em entender a gramática da palavra "um". Como nome próprio de um objeto matemático, esta palavra não admite plural e, desta maneira, o número não pode ser concebido como uma coleção de unidades. ${ }^{14}$.

A questão sobre o que é aquilo a que nos referimos quando proferimos enunciados sobre números permanece, deste modo, em aberto. A resposta fregeana para esta questão parte da prerrogativa, exposta no $\$ 46$ dos Grundlagen, de que o número deve ser considerado no contexto de um juízo que desvela seu uso básico. A partir disso é possível observar que dois juízos terminologicamente diferenciados podem tratar sobre o mesmo objeto e que a diferença entre os termos da sentença corresponde a uma modificação de seu conteúdo conceitual. Isto sugere que o conteúdo conceitual de um enunciado que envolve números é uma asserção sobre um conceito:

\footnotetext{
${ }^{12}$ Frege, 1974, p. 236 [21].

${ }^{13}$ Frege, 1974 , p. 238 [21].

${ }^{14}$ Frege, 1974, p. $244[21]$.
} 
Se digo: "Vênus tem 0 luas", não há absolutamente nenhuma lua ou agregado de luas sobre o que algo se pudesse enunciar; mas ao conceito "lua de Vênus" atribui-se deste modo uma propriedade, a saber, a de não subsumir nada. Se digo "a carruagem do imperador é puxada por quatro cavalos", atribuo o número quatro ao conceito "cavalo que puxa a carruagem do imperador". ${ }^{15}$

A aplicação metodológica do Princípio do Contexto fregeano possibilita o insight de que números são propriedades de segunda ordem, aplicáveis somente a outros conceitos. Ao atentar para o contexto do uso básico da linguagem, Frege estabelece uma distinção entre o conteúdo conceitual de um termo e o objeto ao qual este se refere. Com o amadurecimento da teoria semântica fregeana ${ }^{16}$, a noção de conteúdo conceitual passará a ser chamada de pensamento [Gedanke $]^{17}$. Um pensamento é o conteúdo de uma expressão linguística composta por nomes que possuem um significado [Bedeutung] e um sentido [Sinn], este último tomado como o modo de apresentação de um objeto.

Apesar de o Tractatus repetir o dito fregeano em alguns aforismos, sua teoria semântica possui trilhos próprios. De acordo com Frege, o sentido de uma sentença é uma entidade abstrata com a qual temos contato quando pensamos, enquanto para o primeiro Wittgenstein este sentido é uma possibilidade de existência ou não-existência de fatos atômicos. Frege defende que uma sentença gramatical bem formada, além de possuir um sentido equivalente ao pensamento por ela veiculado, possui também um significado, que é o Verdadeiro ou ao Falso. Wittgenstein vai de encontro a esta ideia ao defender que proposições e nomes são diferentes porque as primeiras possuem apenas sentido, enquanto os últimos correspodem somente a seus significados ${ }^{18}$. Enquanto Frege considera proposições e nomes de maneira semelhante, pois ambos possuem sentido e referência, para Wittgenstein há uma diferença categorial entre o nome e a proposição. Sendo assim, o uso tractariano do Princípio do Contexto deve ser considerado pormenorizadamente, pois não se trata de uma mera reprodução da posição esboçada por Frege.

A primeira aplicação do Princípio do Contexto nos Grundlagen exemplifica uma metodologia de investigação que observa o uso significativo da linguagem e propõe a distinção entre aquilo que a proposição quer dizer e os objetos aos quais ela se dirige. Trata-se, deste modo, de um "princípio guia na elucidação sintático categorial"19 da linguagem. A ideia de que uma atenção

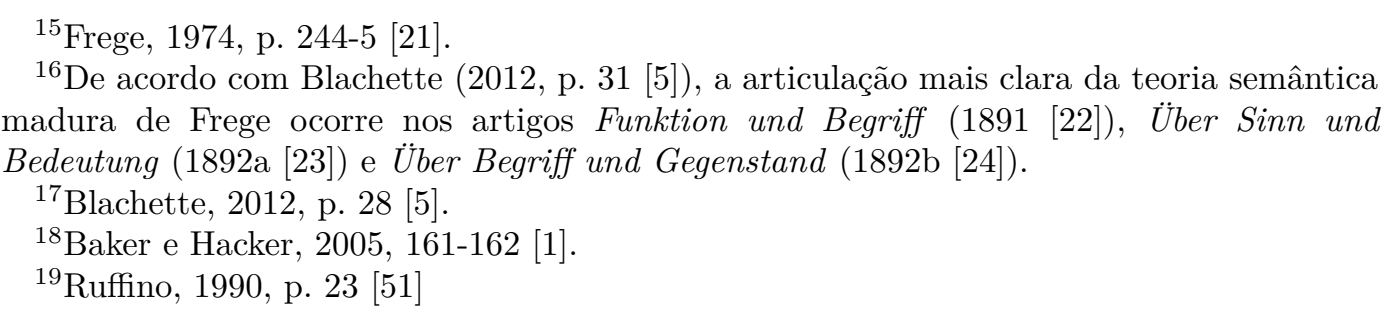


ao contexto básico de uso de uma expressão linguística revela algo sobre a gramática da linguagem e possibilita o alcance de aspectos essenciais da noção de significado é uma herança fregeana que constitui um aspecto central da filosofia wittgensteineana. A versão metodológica do Princípio do Contexto é utilizada por Wittgenstein em sua distinção entre símbolo [Symbol] e sinal $[\text { Zeichen }]^{20}$. Um sinal é qualquer aspecto perceptível da linguagem (T 3.32), como os pixels que são vistos na tela de um computador ou os relevos marcados em papel para leitura tátil, enquanto o símbolo é qualquer parte da proposição que caracteriza seu sentido ( $\mathrm{T}$ 3.31). Para que o símbolo determine uma forma lógica e possa ser identificado no sinal é preciso que nos atenhamos a seu uso significativo, seu emprego lógico-sintático (T 3.326-7).

A análise conceitual fregeana, marcada pela distinção entre o conteúdo conceitual e a extensão de conceitos, tem como objetivo oferecer uma definição precisa da noção de número. Frege constrói os números naturais em termos de conceitos equinuméricos, de tal maneira que o número zero é tomado como a classe de todas as classes cujos elementos correspondem equinumericamente àqueles do conceito correspondente a " $x$ é diferente de si mesmo". Como nada pode ser diferente de si mesmo, o número zero corresponde à classe de todos os conceitos cuja extensão é vazia. O número um, por sua vez, é a classe das classes equinuméricas ao conceito " $x$ é igual a zero"; o número dois, a classe das classes equinuméricas ao conceito " $x$ é igual a zero ou $x$ é igual a um - e assim por diante ${ }^{21}$. A primeira ocorrência do dito fregeano estabelece a necessidade de considerarmos termos númericos no contexto de um juízo que traz à tona seu uso básico, permitindo o alcance de um insight sobre a significatividade da linguagem. A análise que desemboca na concepção de número fregeana parte de uma afirmação mais forte do Princípio do Contexto, condicionando a significatividade de um nome ao contexto de uma sentença:

Deve-se porém atentar sempre a uma proposição completa. Apenas nela têm as palavras propriamente significado. [...] É suficiente que a proposição como um todo tenha sentido; isto faz com que também suas partes ganhem conteúdo. ${ }^{22}$

Esta diretriz possui, deste modo, um aspecto semântico determinante utilizado na explicação da tese epistemológica que motiva o logicismo fregeano, qual seja, a ideia de que a aritmética que deve ser redutível à lógica. ${ }^{23}$. O significado de um termo numérico deve ser analisado não isoladamente, mas

\footnotetext{
${ }^{20}$ cf. Conant, 2001, p. 24 [7].

${ }^{21}$ Reck, 2007, p. 36 [49]

${ }^{22}$ Frege, 1974, p. 253 [21].

${ }^{23}$ Ruffino, 1990, p. 59 [51].
} 
no contexto de uma proposição que assere a igualdade numérica entre dois conceitos. A partir do Princípio de Hume, esta igualdade será entendida como a correspondência biunívoca entre os elementos que compõem a extensão dos conceitos analisados ${ }^{24}$. A identidade é tomada como uma relação entre dois conceitos que compõem o conteúdo de um juízo e correspondem a um mesmo objeto.

No Tractatus, há duas ocorrências nas quais o Princípio do Contexto é tomado explicitamente como uma condição para que uma expressão linguística tenha significado:

3.3 Só a proposição tem sentido [Sinn]; é só no contexto da proposição que um nome tem significado [Bedeutung].

3.314 A expressão [Aüsdruck] só tem significado [Bedeutung] na proposição. Toda variável pode ser concebida como variável proposicional.

(Inclusive o nome variável)..$^{25}$

De acordo com Wittgenstein, o signo proposicional é um fato e somente fatos podem expressar um sentido ( $\mathrm{T}$ 3.142-3). As situações figuradas pelas proposições não podem ser nomeadas ( $\mathrm{T}$ 3.144) porque os nome próprios, ou signos simples (T 3.202), significam objetos (T 3.203). A proposição pressupõe uma articulação estrutural definida e não é, deste modo, apenas um conjunto de nomes ( $\mathrm{T}$ 3.141). O aforismo 3.314 apresenta, contudo, a ideia de um "nome variável", que deve ser concebido como uma variável proposicional. Uma expressão [Aüsdruck], assim como um nome, só possui significado [Bedeutung] no contexto de uma proposição. Este aforismo motiva a interpretação de que um objeto tractariano deve ser entendido como o valor de um nome variável, uma noção puramente lógica chamada de "conceito formal" 26 . Nas palavras de Ishiguro:

O que o 3.3 expressa é a tese geral sobre expressões e os objetos que elas designam, os quais claramente derivam das Fundações da Aritmética de Frege, que não avança tais visões sobre nomes. Nós veremos que a noção de objeto simples de Wittgenstein fez ele tomar essa visão ainda mais seriamente. Não se pode procurar pela referência de nomes independentemente de seu uso em proposições. ${ }^{27}$

${ }^{24}$ Frege, 1960 , p. $73-4$ [25].

${ }^{25}$ Wittgenstein, 2017, p. 145 e 147 [60].

${ }^{26}$ Ishiguro, 1969, p. 27 [34].

27"What 3.3 expresses is a general thesis about expressions and the objects they designate, which plainly derives from Frege's Foundations of Arithmetic, which does not advance such views about names. We will see that Wittgenstein's notion of simple objects made him take this view even more seriously. One cannot look for the references of Names independently of their use in propositions." (Ishiguro, 1969, p. 22 [34].) 
A ideia geral, de inspiração fregeana, seria a de que não é possível ver como um nome se refere a um objeto sem entender sua função em proposições ${ }^{28}$. Esta interpretação afirma que a tese do aforismo 3.3 concerne à relação entre expressões e os objetos por elas designados, pressupondo que a noção de expressão é equivalente à noção de nome. É preciso observar, contudo, que a relação entre uma expressão [Aüsdruck] e aquilo que ela designa não é exposta no aforismo 3.3, mas sim no 3.314. É importante entender porque Wittgenstein se preocupa em afirmar o Princípio do Contexto duas vezes, quase consecutivamente, com uma mudança terminológica significativa.

A parte característica do sentido de uma proposição pode ser chamada tanto de expressão [Ausdrück] quanto de símbolo (T 3.31). A versão metodológica do Princípio do Contexto é incorporada ao Tractatus na ideia de que só no emprego lógico-sintático de um nome é possível identificar o símbolo no sinal. Distinguir dois símbolos que possuem o mesmo sinal é possível através da constatação de diferentes modo de significação ( $\mathrm{T}$ 3.321). Um modo de significação é, por sua vez, um emprego lógico-sintático $(\mathrm{T} 3.323)^{29}$. A identificação do símbolo no sinal pressupõe uma versão heurística do princípio ao afirmar que um símbolo ou modo de significação só pode ser identificado no contexto de sua aplicação lógico-sintática (T 3.326). O que está em jogo nesta formulação não é significatividade de um nome, mas a determinação de uma forma lógica ( T 3.327).

A formulação semântica do Princípio do Contexto, claramente afirmada no aforismo 3.3, estabelece que um nome só possui significado no contexto de uma proposição. No aforismo 3.314, fala-se que a expressão (ou símbolo) não o nome - possui significado na proposição (T 3.314). Essas observações proporcionam a enunciação de três ditames distintos:

P1: Somente no emprego lógico-sintático de um sinal a forma lógica pode ser determinada.

P2: Somente no contexto de uma proposição o significado de uma expressão pode ser determinado.

P3: Somente no contexto de uma proposição o significado de um nome pode ser determinado.

Observamos que P1, enquanto expressão da versão metodológica do Princípio do Contexto, não envolve diretamente a noção de significado. Não podemos, de fato, identificar a referência de nomes fora de sua função sintática em proposições. Com a atenção ao contexto de uso de um termo, contudo,

${ }^{28}$ Ishiguro, 1969, p. 23 [34].

${ }^{29}$ Johnston, 2007, p. 369 [36]. 
alcançamos um símbolo, i.e., o emprego lógico sintático de um sinal ${ }^{30}$. A ideia de significado só aparece explicitamente nas duas formulações seguintes, respectivamente com respeito às noções de expressão e nome próprio.

De acordo com o Tractatus, a relação que se mantém entre linguagem e mundo é estabelecida através da nomeação (T 4.0312). Entretanto, é notável o fato de uma descrição completa do mundo, por meio de proposições completamente generalizadas, dispensar a correlação de um nome com um objeto particular ( $\mathrm{T}$ 5.526). Se a possibilidade do caráter determinado do sentido repousa sobre a postulação de signos simples que se referem a objetos também simples, é difícil explicar a sua dispensabilidade na descrição do mundo. A contradição que se instaura (nomes são ao mesmo tempo indispensáveis e dispensáveis) pode ser aplacada através da atenção quanto ao conceito de expressão, cujo significado difere substancialmente daquele referente aos nomes próprios: enquanto estes últimos se referem a objetos simples, uma expressão é uma variável cujos valores são proposições (T 3.313).

Neste sentido, os valores de uma variável proposicional são o "significado" de expressões e são fixados a partir da descrição de proposições que contém a própria expressão. O nome é um sinal primitivo que não pode ser analisado por meio de definições ( T 3.26) e seu significado é um objeto que não pode ser composto ( T 2.021). A descrição das expressões, i.e., a descrição de todas as proposições que compõem o valor de uma variável, é pressuposta na sintaxe lógica e seu o estabelecimento não depende do significado de nenhum sinal ( $\mathrm{T}$ 3.33). É preciso lembrar que há uma diferença entre os modos de significação de um sinal complexo e de um sinal primitivo ( $\mathrm{T}$ 3.261). O nome variável é um sinal complexo cujo significado é constituído por proposições. O objeto, enquanto significado de um sinal simples é irrelevante na descrição completa do mundo porque esta utiliza variáveis proposicionais, cujo 'significado' pressupõe somente descrições de classes de proposições.

Cuter entende que o conceito de expressão é utilizado por Wittgenstein para transformar o nome próprio numa variável proposicional, subvertendo o uso fregeano do Princípio do Contexto ao aplicá-lo a expressões linguísticas insaturadas:

É neste sentido que é possível afirmar que 'só no nexo proposicional um nome tem referência'. É somente na medida em que incorpora, na forma de regras sintáticas, todas aquelas possibilidades combinatórias que lhe permitem espelhar a forma lógica de um objeto que um sinal pode tornar-se símbolo desse objeto, designando-o. Wittgenstein dá a

${ }^{30}$ Johnston, 2007, p.370 [36]. 
esta afirmação o sentido mais radical possível, transformando o nome num caso particular das funções proposicionais. ${ }^{31}$

Para designar um objeto, além de substituí-lo no nexo proposicional, o nome deveria espelhar a sua forma lógica, esta última entendida como todas as suas possibilidades combinatórias. Um nome variável assinala uma forma, ao atuar como uma marca comum de uma classe de proposições (3.311), e um conteúdo, concernente à fixação dos valores da variável proposicional numa descrição que trata apenas de símbolos.

Com efeito, se o nome é uma variável proposicional e a fixação dos valores desta variável trata apenas de símbolos, não de seu significado (T 3.317), como explicar a relação entre o nome e o objeto? Se o sinal simples denota o objeto, porque a fixação de seu conteúdo dispensa a tratativa de seu significado? Uma saída para esse entrave envolve reconhecer que as noções de nome ( $\mathrm{T}$ 3.3) e expressão ( $\mathrm{T}$ 3.314) remontam a dois conceitos diferentes: no primeiro caso, trata-se de um nome constante e, no segundo, de um nome variável. Em P2, o Princípio do Contexto é aplicado à variáveis proposicionais, que são expressões insaturadas, enquanto em P3 o dito envolve o nome próprio, que é uma expressão saturada. O nome variável e o nome próprio possuem modos de significação diferentes e, por consequência, às duas ocorrências do Princípio do Contexto correspondem símbolos distintos.

Além disso, a utilização do princípio no aforismo 3.314 do Tractatus é bastante próxima a uma ocorrência menos famosa do dito na obra fregeana, no texto intitulado Über die Grundlagen der Geometrie ${ }^{32}$. No artigo em questão, Frege desenvolve uma discussão sobre a necessidade de uma linguagem sem ambiguidades, que evite os vacilos da linguagem ordinária. A defesa da necessidade de conceitos vagos na ciência poderia partir do uso de letras em matemática, como no caso da proposição $(a+b) . c=a \cdot c+b \cdot c$, na qual a letra $a$, por exemplo, denotaria hora o número 2 , hora um número qualquer, ou mesmo vários números. Na visão de Frege, porém, isso é um equívoco. Essas variáveis possuem uma natureza diferente de signos numéricos como '2' e signos para relações como '=', pois não designam, não denotam; sua função é contribuir para a expressão do pensamento, mas isso só pode ocorrer no contexto de uma proposição:

Primeiramente podemos pensar nas letras usadas na matemática se queremos defender a ambiguidade dos sinais. Mas estas letras são de um gênero completamente diferente dos numerais ' 2 ', ' 3 ', etc., ou dos sinais para relações ' $=$ ', '>'. Elas não devem significar de maneira

${ }^{31}$ Cuter, 2002, p. 91 [9].

${ }^{32}(1906[26])$. 
nenhuma números, conceitos, relações, ou quaisquer funções, mas sim devem apenas ser indicadas para conferir generalidade de conteúdo às proposições nas quais ocorrem. Portanto, apenas no contexto de uma proposição elas possuem uma determinada função a cumprir, contribuindo para a expressão do pensamento. ${ }^{33}$

A contribuição do uso de letras variáveis em matemática para a expressão do pensamento é dar generalidade de conteúdo à proposição na qual elas ocorrem. Na proposição $(a+b) . c=a . c+b . c$ não são expressos vários pensamentos, como aquele contido em $(2+3) .7=2.7+3.7$ ou outro qualquer. Estas proposições são diferentes, pois a primeira possui uma generalidade que a segunda não possui, apesar de ambas expressarem cada qual um único pensamento.

O conceito de expressão no Tractatus é um expediente utilizado por Wittgenstein de uma maneira análoga à explicação de Frege sobre a natureza funcional das letras em matemática, para elucidar a generalidade da noção tractariana de forma lógica. O aforismo 3.315 explica como o uso de variáveis proposicionais acarreta a identificação de uma classe de proposições que corresponde a uma forma lógica ou protótipo lógico de figuração:

3.315 Se transformarmos em variável uma parte constituinte de uma proposição, há uma classe de proposições que são todos os valores da proposição variável assim originada. Em geral, essa classe depende ainda do que nós, segundo uma convenção arbitrária, queremos significar com partes daquela proposição. Se transformarmos em variáveis, porém, todos os sinais cujo significado foi arbitrariamente determinado, ainda assim continua a haver tal classe. Esta, porém, não depende mais de qualquer convenção, mas apenas da natureza da proposição. Ela corresponde a uma forma lógica - a um protótipo lógico de figuração. ${ }^{34}$

A parte constituinte de uma proposição é um nome próprio, que denota um objeto simples. Deste modo, os nomes 'a', 'B' e 'c' exemplificam a proposição 'aBc', que representa sua situação correspondente. Para identificar uma parte proposicional que expressa aquilo de essencial para seu sentido, é preciso transformar um nome constante numa variável. Se substituirmos 'a' por ' $x$ ', obtendo assim a expressão 'xBc', obtemos a classe de proposições originada por essa substituição e os valores que a variável ' $\mathrm{x}$ ' pode assumir são os nomes admissíveis nesse nexo proposicional. Se 'b', 'c' e 'd', são os nomes que podem

33"Zunäst kann man an den Gebrauch der Buchstaben in der Mathematik denken, wenn man die Vieldeutigkeit der Zeichen verteidigen will. Aber die Buchstaben sind ganz anderer Art als die Zahlzeichen $» 2 \ll » 3 \ll$ usw. oder als die Beziehungszeichen $»=« »>\ll$. Sie sollen garnicht Zahlen, oder Begriffe, oder Beziehungen, oder irgendwelche Funktionen bezeichnen, sondern sie sollen nur andeuten, um dem Satze, in dem sie vorkommen, Allgemeinheit des Inhalts zu verleihen. Also nur im Zusammenhange eines Satzes haben sie eine gewisse Aufgabe zu erfüllen, haben sie zum Gedankenausdrucke beizutragen." (Frege, 1906, p. 307 [26])

${ }^{34}$ Wittgenstein, 2017, p. 147 [60]. 
ocorrer neste exemplo, o conteúdo da expressão corresponde às proposições $\mathrm{bBc}, \mathrm{cBc}$ e dBc.

Se todos os nomes forem substituídos por variáveis, existirá uma classe correspondente que não depende da correlação arbitrária de um nome a qualquer objeto, mas somente da natureza da proposição. Esta classe, que corresponde a uma forma lógica, é formada por todas as combinações possíveis de nomes admissíveis na forma da expressão. O resultado da aplicação do conceito de expressão é o alcance de proposições totalmente generalizadas, por meio das quais podemos descrever o mundo completamente sem pressupor que um nome possua um significado específico (T 5.526). Deste modo, o Tractatus permite a possibilidade de que haja nomes em proposições completamente generalizadas - os nomes variáveis -, mas estes só podem ser correlacionados a objetos não especificados ${ }^{35}$. O significado que as expressões só possuem no contexto de uma proposição é, portanto, diferente do significado de um nome próprio. É por isso que Wittgenstein se preocupa em afirmar novamente, no aforismo 4.23, que o nome só ocorre nas proposições no contexto de uma proposição elementar, enquanto o uso do nome variável se dá no contexto de uma proposição cujo conteúdo são classes de proposições.

A generalidade alcançada pela noção de expressão, com a substituição de todos os nomes constantes por nomes variáveis numa proposição, é justamente o aspecto que diferencia a forma de afiguração da forma lógica de afiguração, explicadas respectivamente nos aforismos 2.17 e 2.18. A diferença entre um nome variável e um nome constante marca a distinção entre P2 e P3. O Princípio do Contexto fregeano é aplicável a termos variáveis que substituem termos númericos no contexto de equações matemáticas, cuja função é a de dar generalidade ao pensamento expresso pelo enunciado no qual ocorrem. O uso de variáveis que cumprem a mesma função no Tractatus é também prenunciado pelo princípio, exposto no aforismo 3.314, que trata sobre a significatividade de uma expressão. Aquilo que expressões significam, diferentemente dos nomes próprios, são classes de proposições, e uma expressão totalmente generalizada - cuja classe corresponde a todas as combinações possíveis de nomes corresponde a uma forma lógica.

Isso explica porque uma descrição completa do mundo dispensa o uso de nomes, empregando variáveis que não desempenham a função de denotar um objeto específico. O emprego das variáveis pressupõe a substituição de nomes constantes cuja referência fixa garante a determinação do sentido proposicional. A expressão apresenta a forma lógica de afiguração como uma matriz ou protótipo lógico que se mostra em proposições completamente generalizadas.

\footnotetext{
${ }^{35}$ Cheung, 2005, p. 21 [6].
} 
Nomes ainda estão envolvidos na descrição completa do mundo na forma de expressões ou nomes variáveis, cuja aplicação pressupõe outras proposições nas quais ocorrem nomes próprios passíveis de substituição. Existe, deste modo, um nível mais básico de significação no qual o nome desempenha seu papel denotativo, e um nível de aplicação de nomes variáveis que apenas pressupõem este papel na descrição do mundo.

A enunciação de P2 concerne ao conceito de expressão e explica a noção de forma de afiguração lógica exposta no aforismo 3.315. À diferença entre as formulações do Princípio do Contexto nos aforismos 3.3 e 3.314 corresponde a distinção tractariana entre nomes e proposições - ou, no caso do conceito de expressão, uma variável proposicional cujo significado são proposições. A forma lógica de afiguração é o que permite que a figuração represente o mundo, entendido como a totalidade dos fatos. A noção de significado que ocorre em P3 é relativa ao nome próprio, que denota um objeto e, como consequência, a formulação do aforismo 3.3 resulta num conceito distinto dessa forma lógica. Este resultado é oriundo de um movimento conceitual do primeiro Wittgenstein que vai de encontro a uma importante prerrogativa fregeana. O problema emergente nessa discussão diz respeito à independência do significado e nos remete, fortuitamente, ao conflito entre demandas holistas e atomistas.

\subsection{1}

\section{Limites do Princípio e Forma dos Objetos}

Como observa Cuter, a ocorrência do Princípio no aforismo 3.3 se dá quase que em tom de paródia do dito fregeano colocado nos Grundlagen. Um problema específico parece justificar seu esforço na defesa de que o Tractatus transgride o Princípio do Contexto de Frege ao aplicá-lo a uma variável proposicional. O argumento da substância funciona como uma garantia para a determinação do sentido de uma proposição, através da postulação de objetos simples que são a referência dos nomes tractarianos e existem independentemente do que é o caso. O Princípio do Contexto, por outro lado, atrelaria a significatividade do nome ao nexo proposicional, como se seu significado dependesse, de alguma maneira, do sentido da proposição

[...] é como se o princípio ameaçasse subverter a ordem das determinações semânticas, que deveria ir dos significados dos nomes para o sentido da proposição, deixando-nos a um passo de afirmar que o sentido da proposição deve estar dado para que possamos determinar o significado de cada um dos nomes que a compõem. ${ }^{36}$

${ }^{36}$ Cuter, 2002, p. 90 [9]. 
A exposição de Cuter revela os termos de um conflito entre a independência da substância do mundo (T 2.024) quanto aos fatos e a dependência do significado de um nome com relação ao nexo proposicional. Defender que o Princípio do Contexto no Tractatus transforma o nome numa variável proposicional parece ser uma maneira de deter este conflito, evitando dar centralidade à ideia de que o significado de um nome é, de alguma maneira, dependente do sentido da proposição na qual ele ocorre.

O problema em questão é antevisto por Frege, que concebe o significado de uma palavra numérica como algo objetivo e auto-subsistente ${ }^{37}$. Afirmar esta auto-subsistência sobre o número não significa dizer que uma palavra numérica possui significado fora do contexto de uma proposição. Em outras palavras, a independência do significado não implica a independência da significatividade de um nome, que só possui referência no nexo proposicional e é, deste modo, dependente de sua ocorrência na proposição. Do mesmo modo, a dependência da significatividade do nome com relação à proposição não acarreta o mesmo tipo de dependência para seu significado. A terminologia fregeana é cuidadosa ao tratar número [Zahl] e numeral [Zahlwort] em termos distintos ${ }^{38}$. É importante observar esta distinção porque, dada a auto-subsistência de um número, é fácil cometer o engano de considerar o significado de um numeral isoladamente. A aplicação do Princípio do Contexto na análise do conceito de número diz respeito a numerais e a dependência destes com relação ao contexto da proposição não se estende a seus significados, cuja existência é totalmente independente e autossuficiente.

A versão semântica do Princípio do Contexto, afirmada por Frege nos Grundlagen, não é encontrada em nenhum trabalho subsequente. Isto sugere, de acordo com Dummettt, que a abordagem fregeana desenvolve uma nova doutrina de 1890 em diante, abandonando a ideia de que a sentença possui a função distinta de permitir a determinação do significado de um nome pela ideia de que sentenças podem ser vistas como nomes próprios ${ }^{39}$. Contudo, como notam Baker e Hacker ${ }^{40}$, sentenças são comparadas a nomes próprios já no Begriffsschrift ${ }^{41}$, o que torna difícil entender como esta posição entra em conflito com o Princípio do Contexto. Uma das razões que Frege teria para retirar, com o desenvolvimento de sua teoria semântica madura, a centralidade dada a este princípio nos Grundlagen, é abordada na seguinte passagem de seu famoso artigo Über Sinn und Bedeutung:

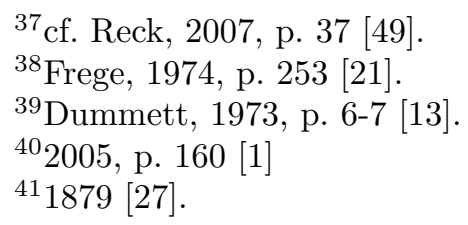


O julgar é na verdade algo totalmente peculiar e único. Poderse-ia dizer que julgar consiste em distinguir partes dentro do valor de verdade. [...] Tenho, porém, empregado aqui a palavra "parte" de um modo peculiar: transferi a relação entre todo e parte da sentença para sua referência, Isto o fiz ao conceber a referência de uma palavra como parte da referência de uma sentença, quando a própria palavra é parte da sentença. Certamente, esta maneira de falar é discutível, porque, no que diz respeito à referência, o conhecimento do todo e de uma de suas partes não determina a outra parte, e também porque a palavra "parte", quando aplicada aos corpos, é empregada em outro sentido. ${ }^{42}$

O significado de uma palavra que ocorre como parte de uma sentença pode ser tomado como parte do significado desta última. Contudo, a relação que existe entre um nome e a sentença não pode ser confundida com aquela que se mantém entre o objeto ao qual o nome se refere e o significado da sentença, que diz respeito a um valor de verdade. Existe, então, um sentido no qual a palavra 'parte' é utilizada para corpos, que são divisíveis, assim como uma sentença pode ser dividida em partes, mas que não pode ser aplicado à noção de significado. $\mathrm{O}$ valor de verdade, que é a totalidade do significado de uma sentença, não é suficiente para determinar um objeto significado por um nome que faz parte desta sentença. Tampouco um objeto pode determinar um valor de verdade, pois os dois, enquanto significados de termos linguísticos, são independentes. Sendo assim, apesar de o nome somente possuir significado no contexto de uma proposição, a existência do objeto por ele denotado não depende do valor de verdade correspondente à sentença como um todo. Este modo de falar pode ser atacado porque o significado de um nome, que para Frege deve ser auto-subsistente e portanto independente, passaria a ser dependente do significado de uma sentença - e um objeto não pode ser, ao mesmo tempo, dependente e independente.

A dependência acarretada pelo Princípio do Contexto é limitada a palavras e sentenças, não sendo estendida ao significado, à referência de signos linguísticos. Quando Wittgenstein trata sobre os objetos, que são a referência dos signos simples, o limite observado por Frege não é respeitado. Isso acontece porque a concepção de linguagem apresentada no Tractatus toma proposições como modelos da realidade em sua função figurativa. Figurações representam situações no mundo e são elas mesmas também fatos. Linguagem e realidade são aproximadas de uma tal maneira que em muitas ocasiões é possível traduzir diretamente afirmações que envolvem termos linguísticos utilizando conceitos ontológicos $^{43}$. O postulado tractariano dos signos simples que possibilita o

\footnotetext{
${ }^{42}$ Frege, 2009, p. 141 [28].

${ }^{43}$ Este aspecto da filosofia do primeiro Wittgenstein pode ser debitário de seu parentesco com a teoria de Russell, que de acordo com Hyder (2002, p. 7 [33].) toma os objetos do
} 
caráter determinado do sentido (T 3.23), por exemplo, aparece nos Notebooks como a demanda pelas coisas simples ${ }^{44}$. Os aforismos 2.062 e 5.135, por sua vez, são praticamente uma tradução, em termos ontológicos, da tese da independência das proposições elementares colocada no 5.134:

2.062 Da existência ou inexistência de um fato atômico não se pode concluir a existência ou inexistência de outro.

5.134 De uma proposição elementar, nenhuma outra se pode deduzir.

5.135 Da existência de uma situação qualquer não se pode, de maneira nenhuma, inferir a existência de uma situação completamente diferente dela. ${ }^{45}$

Do mesmo modo, o Princípio do Contexto colocado no aforismo 4.23 encontra sua contraparte ontológica no 2.0121:

2.0121 Se posso pensar no objeto na liga [Verbande] do fato atômico, não posso pensar nele fora da possibilidade dessa liga.

$4.23 \mathrm{O}$ nome aparece na proposição apenas no contexto [Zusammenhange] da proposição elementar. ${ }^{46}$

Assim como a possibilidade da aparição do nome na proposição elementar é atestada pelo Princípio do Contexto, a possibilidade do aparecimento de um objeto em fatos atômicos constitui sua forma (T 2.0141).

A relação de dependência entre o nome próprio e a proposição elementar é estendida, no Tractatus, aos objetos, que possuem a mesma dependência quanto à liga do fato atômico. Explicamos a forma dos objetos como a capacidade, inerente à natureza de um objeto, de ocorrência em fatos atômicos. Isso pode ser observado com uma atenção ao aforismo 2.0122, que compara o vínculo da coisa com o fato atômico com aquele mantido entre o nome e a proposição:

2.0122 A coisa é autossuficiente, na medida em que pode aparecer em todas as situações possiveis, mas essa forma de autossuficiência é uma forma de vínculo com o fato atômico, uma forma de não ser autossuficiente. (É impossível que palavras intervenham de dois modos diferentes, sozinhas e na proposição). ${ }^{47}$

A consequência ontológica de que a coisa é de certa forma dependente do fato atômico no qual deve poder ocorrer, assim como o nome depende de sua ocorrência na proposição, acontece aqui em dissonância com a recomendação

pensamento e os atos cognitivos de um sujeito como pertencentes ao mesmo nível ontológico.

${ }^{44}$ Wittgenstein, 1969, p. 63 [62].

${ }^{45}$ Wittgenstein, 2017, p. 135 e 195 (tradução modificada) [60].

${ }^{46}$ Wittgenstein, 2017, p. 131 e 177 (tradução modificada) [60].

${ }^{47}$ Wittgenstein, 2017, p. 131 (tradução modificada) [60]. 
fregeana de que o significado deve ser totalmente autossuficiente. A forma dos objetos incorpora, deste modo, um aspecto holista em sua formulação com a definição de sua existência independente dada em função de sua essencial concatenabilidade com outros objetos.

Constatamos que as noções de forma no Tractatus sempre trazem consigo a ideia de possibilidade. A forma dos objetos, entendida como sua capacidade essencial de conexão com outros, é a possibilidade da estrutura de um fato atômico. A possibilidade de que os nomes de uma proposição elementar e os objetos de um fato atômico estejam configurados de modo a compartilhar a mesma estrutura é chamada de forma de afiguração. Sendo assim, chegamos à possibilidade da forma de afiguração, que permite a representação de situações na linguagem, com base na ideia de que os fatos atômicos possuem uma certa estrutura resultante da combinação de objetos e que a possibilidade desta combinação é garantida pelo objeto por si só, pela sua essência. Pela aplicação do Princípio do Contexto na ontologia tractariana, chegamos à enunciação de mais uma versão do princípio que é resultado da tradução de P3 em termos ontológicos:

P3: Somente no contexto de uma proposição o significado de um nome pode ser determinado.

P4: Um objeto só pode existir na sua possível ocorrência em um fato atômico.

Isso implica reconhecer que o objeto é essencialmente dependente do fato atômico, assim como o significado de um nome depende de sua ocorrência no nexo de uma proposição. Como a possibilidade da estrutura de um fato atômico é um pressuposto para a forma de afiguração, a forma dos objetos é anterior à sua formulação.

A proposição pode alcançar todo o espaço lógico por ser uma figuração lógica, e para tanto deve possuir uma forma lógica de afiguração correspondente a um protótipo lógico visto na aplicação de variáveis proposicionais. Que há uma forma lógica pode ser visto no fato de haver uma classe de proposições correspondentes a uma proposição totalmente generalizada. Por meio deste tipo de proposição, que usa nomes variáveis e somente pressupõe nomes em sua função de representar objetos, é possível que a proposição descreva o mundo completamente. A aplicação do Princípio do Contexto ao conceito de expressão, no aforismo 3.314, resulta na noção tractariana de forma de afiguração lógica. A ocorrência do dito no aforismo 3.3, por sua vez, é aplicada aos nomes próprios e extendida, pela íntima conexão entre linguagem e mundo, 
aos objetos, resultando na noção de forma dos objetos que antecede a noção de forma de afiguração. 


\section{Objeto Tractariano e Análise Clarificatória}

Vimos que a formulação da noção de objeto no Tractatus apresenta uma certa tensão que pode ser identificada na manutenção de duas atitudes opostas quanto a seus pressupostos. O ponto chave desta oposição é a questão sobre a exemplificação de objetos simples através do trabalho filosófico. A tensão assim instaurada envolve a ideia de que exemplos não são necessários porque a investigação filosófica não deve recorrer a dados fornecidos pela experiência - um pressuposto explicitamente defendido mas diretamente conflitante com algumas observações que desenvolvem o que parecem ser claros exemplos para objetos tractarianos. A analogia que ocorre nos aforismos 2.013-2.0131, que aproxima objetos a itens de natureza fenomênica como "ponto no espaço visual", é responsável por um acirramente da oposição evidenciada, pois a elucidação nela desenvolvida compromete a ideia de que a substância é ultimamente simples. No Tractatus, objetos são apresentados como entidades que subsistem independentemente dos fatos que ocorrem no mundo e possuem forma e conteúdo. Ser independente significa poder existir em todos os fatos atômicos possíveis. Mais do que isso, se algo não pode ocorrer em fatos atômicos, não pode ser um objeto. Argumentamos que a forma de um objeto, entendida como a capacidade de sua conexão na liga do fato atômico, é resultado da subversão de recomendações fregeanas sobre o Princípio do Contexto. Este princípio condiciona a significatividade de um nome à sua ocorrência na proposição e, para o primeiro Wittgenstein, os significados dos nomes são semelhantemente dependentes de sua ocorrência nos fatos figurados pelas proposições. A demanda de que o objeto seja essencialmente dependente de fatos atômicos integra a explicação sobre a sua subsistência independente, tornando sua formulação internamente inconsistente. A existência do objeto simples está contida na ideia de análise e, ao mesmo tempo, as considerações sobre sua natureza comprometem a sua simplicidade absoluta.

No primeiro capítulo vimos que a existência de objetos simples é atestada aprioristicamente na ideia de análise lógica. A substância deve existir para que figurações verdadeiras ou falsas possam acontecer, pois o sentido de uma proposição não pode depender da verdade de outras proposições. A postulação dos objetos impede, portanto, um regresso comprometedor para a análise final da linguagem, que deve acabar com o alcance de proposições elementares. Apesar de a filosofia ser equiparada à ideia de análise lógica, é notável que esta análise final não pode ser levada a cabo pelo filósofo, pois o 
fornecimento das proposições elementares não está no escopo de seu trabalho. Como consequência, parece existir ao menos um aspecto da análise lógica que foge ao alcance do filósofo, aquele que diz respeito à aplicação da lógica ( $\mathrm{T}$ 5.557); enquanto isso, sua preocupação principal deve ser estabelecer, em bases puramente lógicas, que devem haver proposições elementares.

Nosso próximo passo será entender qual aspecto da análise lógica é relevante para a afirmação da existência do objeto simples e como esta mesma análise identifica a sua dependência quanto ao que ocorre no mundo. A explicação proposta deve satisfazer a ideia de que a referida dependência é concluída com base no Princípio do Contexto e deve abordar a relação deste último com a ideia de análise tractariana. Para tanto, será útil abordar inicialmente as considerações sobre a análise lógica nos Notebooks. Este exame inicial pretende mostrar que a possibilidade de uma análise que desvela objetos infinitamente complexos é seriamente considerada por Wittgenstein em algumas observações. Concluir a simplicidade dos objetos é um movimento que envolve uma distinção entre um modo antigo e um novo modo de análise, calcado na ideia de sintaxe lógica. Isto nos levará à considerações sobre os diferentes modos de análise que permeiam a filosofia do primeiro Wittgenstein, constatando a prevalência de uma análise, denominada clarificatória, em detrimento de uma análise decomposicional, como método de investigação filosófica no Tractatus.

Caracterizaremos a análise clarificatória tractariana com a devida atenção aos modos de análise nela envolvidos, identificando a prevalência dos modos transformativo e regressivo em detrimento do modo decomposicional. Os dois modos de análise identificados conjugam-se na ideia de que o sentido proposicional, assim como o mundo representado pela linguagem, deve ter sempre um caráter determinado que só pode ser explicitado no contexto de um uso regido por regras da sintaxe lógica. O objeto simples, colocado contra o pano de fundo da análise clarificatória, encontra-se intimamente conectado a estas regras sintáticas, cuja natureza também será alvo de nossa investigação neste capítulo.

\section{1}

\section{0 requerimento da análise completa}

Expusemos anteriormente um modo intuitivamente plausível de entender o que significa, para o objeto simples, ter sua existência contida na ideia de análise lógica. Uma proposição é considerada completamente analisada quando seus elementos, denominados sinais simples, correspondem aos objetos do pensamento (T 3.2-3.201). Estes sinais simples, ou nomes próprios, denotam ob- 
jetos (T 3.302-3) e são considerados signos primitivos porque não podem mais ser desmembrados por meio de definições (T 3.26). O alcance da substância é, desta forma, um resultado da análise, na medida em que a decomposição de complexos linguísticos em suas partes mais simples acaba em sinais indecomponíveis que possuem objetos como significados.

Apesar de intuitiva, essa explicação não é satisfatória devido à delimitação da esfera apriorística da investigação filosófica. Dizer quais são as proposições elementares - e ser capaz, assim, de identificar seus nomes e suas respectivas referências - é algo que não compete à filosofia, mas à aplicação da lógica. Em outras palavras, não alcançamos a existência dos objetos através da análise lógica das proposições, mas sabemos sobre essa existência a priori, sem o auxílio de elementos dados a posteriori. Desta maneira, se existe um procedimento de análise por trás da constatação da existência do objeto e de sua simplicidade, este não pode ser identificado com a análise lógica que desvela proposições elementares.

A postulação da existência da substância envolve a saída para um regresso acarretado pela tentativa de basear as condições de significatividade de um enunciado na verdade de outros. O postulado dos signos simples, que possuem objetos simples como significados, é um postulado para o caráter determinado do sentido, pois sem eles a análise desvelaria sempre novas proposições, num processo sem fim. Desta maneira, o final da análise é um requesito para que o sentido proposicional mantenha sua determinação. É importante distinguir, nesse contexto, dois requesitos sobre a análise tractariana. O primeiro diz respeito ao final da análise: é óbvio que a análise desvela proposições elementares cujos nomes designam objetos (T 4.221). Para que esta análise seja completa - i.e., para que seja possível enumerar todos os elementos do complexo denotado pela expressão linguística - objetos não podem ser infinitamente complexos. Esta demanda é diferente da exigência de que esta análise tenha um fim. De um lado temos a ameaça da análise ad infinitum, que compromete a possibilidade de determinação do sentido da proposição ao desvelar sempre novas proposições num processo infindável que não descobre a estrutura básica da linguagem. Por outro lado, é possível que esta análise tenha fim e que os elementos encontrados sejam infinitamente complexos ${ }^{1}$.

O modelo fisicalista para a análise de sensações ${ }^{2}$ reduz sensações visuais a pontos, partindo da definição de complexos espaciais da geometria euclidiana e inferindo que uma parte monocromática da imagem visual de um sujeito é ultimamente composta por um número infinito de pontos ${ }^{3}$. Este é um exemplo

${ }^{1}$ cf. Soutif, 2017, p. 17-21 [54].

${ }^{2}$ cf. Lampert, 2000 [37].

${ }^{3}$ Soutif, 2017, p. $15[54]$. 
de análise infinita seriamente considerado por Wittgenstein como candidato a modelo para sua concepção de análise lógica nos Notebooks. Como pontos não possuem extensão, não podem ser decompostos em partes adicionais e o final da análise é assim garantido. A complexidade infinita dos pontos não é um empecilho para a análise finita preconizada posteriormente no Tractatus. Um problema, surge, contudo, ao considerarmos o requerimento da análise completa, pois é humanamente impossível intuir um número infinito de pontos ao mesmo tempo e os objetos não poderiam, deste modo, ser enumerados, restando apenas seu conhecimento descritivo como resultado da análise. Consequentemente, a ideia de uma análise infinita comprometeria a significatividade de declarações sobre complexos espaciais porque a atribuição de um sentido claro e preciso requer a completude da análise ${ }^{4}$.

Apesar disso, a impossibilidade do conhecimento exaustivo dos elementos e da estrutura de um complexo espacial parece não ser um empecilho para a análise completa da linguagem ${ }^{5}$. Numa nota escrita em junho de 1915, Wittgenstein considera a hipótese de que um nome simples denote um objeto infinitamente complexo:

Ora, mas e se um nome simples significar um objeto infinitamente complexo? Por exemplo, dizemos algo sobre uma mancha em nossa imagem visual, que está à direita de uma linha, e nós assumimos que toda mancha em nossa imagem visual é infinitamente complexa. Falamos então sobre um ponto nesta mancha, o qual está à direita da linha, e esta proposição segue-se da anterior; e se há infinitamente muitos pontos na mancha, então infinitamente muitas proposições de conteúdos distintos seguem-se LOGICAMENTE daquela primeira. E isto mostra que a proposição já era de fato infinitamente complexa. Isto é, não o sinal proposicional por si mesmo, mas juntamente com seu uso lógicosintático. ${ }^{6}$

O exemplo considerado para o objeto simples é o de uma mancha na imagem visual, assumidamente composta por um número infinito de pontos. Dadas estas condições, a sentença "a mancha está à direita da linha" implica logicamente um número infinito de proposições com diferentes conteúdos, pois é possível afirmar sobre cada um dos infinitos pontos da mancha que estes estão

${ }^{4}$ Soutif, 2017, p. 18-9 [54].

${ }^{5}$ Soutif, 2017, p. 19 [54].

6"Wenn nun aber ein einfacher Name einen unendlichen komplexen Gegenstand bezeichnet? Wir sagen zum Beispiel etwas von einem Fleck unseres Gesichtsbilds aus etwa daß er rechts von einer Linie liege und wir nehmen an daß jeder Fleck unseres Gesichtsbilds unendlich komplex ist. Sagen wir dann von einem Punkt in jenem Fleck daß er rechts von der Linie liege, dann folgt dieser Satz aus dem früheren und wenn unendlich viele Punkte in dem Flecken liegen, dann folgen unendlich viele Sätze verschiedenen Inhalts LOGISCH aus jenem ersten! Und dies zeigt schon daß er tatsächlich selbst unendlich komplex war. Nämlich nicht das Satzzeichen allein wohl aber mit seiner syntaktischen Verwendung."(Wittgenstein, 1969 , p. 64 [62]) 
à direita da linha. Isto mostra que a proposição, enquanto signo proposicional unida à sua aplicação lógico-sintática, é infinitamente complexa neste caso.

Contudo, a possível complexidade infinita parece não ser um empecilho para a definição do sentido proposicional:

Mas agora esta possível complexidade infinita do sentido prejudica sua determinação?

Podemos exigir determinação também desta maneira: se uma proposição há de possuir sentido, também o uso sintático de todas as suas partes deve ser estabelecido por ora. - Não podemos, e.g., apenas posteriormente constatar que uma proposição segue-se dela. Mas, e.g., antes dessa proposição poder ter um sentido devem constar completamente quais proposições seguem de uma proposição! ${ }^{7}$

Esta passagem sugere um modo alternativo de exigir a precisão do sentido que envolve estabelecer de antemão o uso sintático de cada uma das partes da proposição. Existe, deste modo, uma perspectiva na qual a análise pode ser concebida de modo que a complexidade infinita dos objetos não configure um empecilho para o caráter determinado do sentido. Entretanto, a análise completa no "sentido antigo" é inviabilizada caso objetos sejam infinitamente complexos:

Vamos assumir que todo objeto espacial consiste de infinitamente muitos pontos, então é claro que eu não posso indicá-los todos pelo nome quando falo sobre aquele objeto. Aqui temos então um caso no qual eu não posso de modo algum chegar a uma análise completa no velho sentido; e talvez seja justamente este o caso habitual. ${ }^{8}$

A análise lógica pode ser tomada, desta maneira, em dois sentidos diferentes nos Notebooks. O aspecto que mantém a determinação do sentido proposicional mesmo no caso de tratarmos sobre objetos infinitamente complexos caracteriza uma dimensão sintática desta análise. A mudança na visão de Wittgenstein sobre a análise é o que torna compatível a hipótese de uma complexidade infinita do objeto e o requerimento de uma complexidade finita para o sentido de um enunciado no qual seu nome ocorre. A complexidade infinita de um

\footnotetext{
7"Aber beeinträchtigt nun diese mögliche unendliche Zusammengesetztheit des Sinnes, dessen Bestimmtheit?

Man könnte die Bestimmtheit auch so fordern: Wenn ein Satz Sinn haben soll so muß vorerst die syntaktische Verwendung jedes seiner Teile festgelegt sein. - Man kann z.B. nicht erst nachträglich draufkommen daß ein Satz aus ihm folgt. Sondern z.B. welche Sätze aus einem Satz folgen muß vollkommen feststehen ehe dieser Satz einen Sinn haben kann!"'(Wittgenstein, 1969, p. 64 [62])

8"Nehmen wir an jeder räumliche Gegenstand bestehe aus unendlich vielen Punkten, dann ist es klar daß ich diese nicht alle namentlich anführen kann wenn ich von jenem Gegenstand spreche. Hier wäre also ein Fall wo ich zur vollständigen Analyse im alten Sinne gar nicht kommen kann; und vielleicht ist gerade dieser der gewöhnliche Fall.”(Wittgenstein, 1969 , p. $62[62])$
} 
objeto não afeta a determinação do sentido porque esta repousa sobre o domínio das regras para o uso de um nome no interior de contextos sentenciais ${ }^{9}$.

Existem três modos distintos que podem ser combinados de maneiras diversas na constituição de práticas específicas de análise: regressivo, resolutivo ou decomposicional e interpretativo ou transformativo ${ }^{10}$. O modo decomposicional é predominante no sentido antigo de análise e envolve a ideia de separação das partes de um analysandum, proporcionando a identificação de seus elementos e de seu arranjo estrutural. A prevalência do modo decomposicional nos primeiros usos da noção de análise na tradição justifica a precedência daquilo a ser encontrado, em detrimento do método mesmo de decomposição e das ferramentas necessárias ao trabalho analítico. Um processo de dissolução química, por exemplo, envolve a decomposição de uma dada substância a partir de sua introdução num solvente apropriado. Para dissolver e decompor algo é preciso encontrar um outro elemento por meio do qual este processo seja possível. O modo regressivo de análise se preocupa com o alcance de algo mais fundamental (princípios, premissas, causas, etc.), por meio do qual um analysandum pode ser explicado.

Todo processo de análise pressupõe também uma estrutura conceitual contra a qual o objeto a ser analisado é interpretado, resultando numa espécie de transformação deste último. Este aspecto da análise caracteriza seu modo transformativo, que pode ser ilustrado pela tratativa de problemas em geometria análitica cuja resolução é precedida pela tradução do problema na linguagem da álgebra e da aritmética ${ }^{11}$. As concepções de análise defendidas por Frege e Russell, dois nomes de reconhecida e fecunda influência no pensamento do primeiro Wittgenstein, são muito próximas ao modo de análise transformativo exemplificado na geometria analítica:

O que Descartes e Fermat fizeram pela geometria analítica, Frege e Russell fizeram pela filosofia analítica. No caso de Frege e Russell, o sistema no interior do qual proposições foram 'traduzidas' era a lógica de predicados, e o processo de tradução ele mesmo tornou-se um tema de preocupação filosófica. O que eu quero sugerir, então, é que a filosofia analítica - ou ao menos, uma vertente central na filosofia analítica - é 'analítica' muito mais no sentido que a geometria analítica é 'analítica' do que no sentido decomposicional bruto que Kant entendeu. ${ }^{12}$

${ }^{9}$ Soutif, 2017, p. 20-1 [54].

${ }^{10}$ Beaney, 2002, p. $55[4]$.

${ }^{11}$ Beaney, 2002, p. 67 [4].

12"What Descartes and Fermat did for analytic geometry, Frege and Russell did for analytic philosophy. In the case of Frege and Russell, the system into which propositions were 'translated' was predicate logic, and the process of translation itself became an issue of philosophical concern. What I want to suggest, then, is that analytic philosophy - or at least, one central strand in analytic philosophy - is 'analytic' much more in the sense that analytic geometry is 'analytic' than in the crude decompositional sense that Kant understood 
O "sentido antigo" aludido por Wittgenstein, no qual a complexidade infinita dos objetos impede a completude da análise, prioriza o modo decomposicional. A compatibilidade entre a demanda pela determinação do sentido e a complexidade infinita de um objeto pode ser explicada como resultado de uma mudança em sua visão sobre como deve ser uma análise completa nos Notebooks, com a incorporação do aspecto transformativo que pode ser encontrado tanto no programa de Russell para frases denotativas ${ }^{13}$ quanto na análise fregeana dos números naturais ${ }^{14}$.

É importante notar, contudo, que apesar de nada "falar contra" a divisibilidade infinita, a situação infinitamente complexa, nas palavras do primeiro Wittgenstein, aparenta ser uma quimera ${ }^{15}$. O motivo para esta afirmação é colocado nos termos de um "sentimento" de que o mundo deve ser constituído por elementos simples:

É A PRIORI claro que nós devemos chegar a componentes simples na decomposição - isso é algo já dado no conceito de decomposição - ou uma decomponibilidade ad infinitum é possível? - Ou há por fim ainda uma terceira opção? [...]

Tampouco podemos falar contra uma decomponibilidade infinita.

E repetidamente impõe-se a nós que há algo simples, indecomponível (Unzerlegbares), um elemento de ser, em suma: uma coisa.

Isso não vai contra nosso sentimento, que nós não podemos decompor PROPOSIÇÕES de modo a indicar seus elementos pelo nome, mas nós sentimos que o mundo deve ser constituído de elementos. E parece que, de maneira idêntica à proposição, o mundo deve ser o que ele é, deve ser determinado. Em outras palavras, o que oscila são nossas determinações, não o mundo. ${ }^{16}$

A ideia da simplicidade do objeto é, deste modo, imposta sobre nós através do importante pressuposto de que mundo e linguagem são, de certa maneira, idênticos. Objetos não podem ser infinitamente divisíveis porque o mundo deve ser o que é de maneira determinada, do mesmo modo que o sentido

it." (Beaney, 2002, p. 67 [4].)

${ }^{13}$ Soutif, 2017, p. 21

${ }^{14}$ Reck, 2007, p. 35 [49].

${ }^{15}$ Wittgenstein, 1969, p. 50 [62].

16 "Ist es, a priori, klar daß wir bei der Zerlegung auf einfache Bestandteile kommen müssen - liegt dies etwa schon im Begriff der Zerlegung -, oder ist eine Zerlegbarkeit ad infinitum möglich? - Oder am Ende gar ein Drittes? [...]

Gegen eine unendliche Zerlegbarkeit scheint auch nichts zu sprechen. Und immer wieder drängt es sich uns auf daß es etwas einfaches Unzerlegbares gibt, ein Element des Seins kurz ein Ding.

Es geht zwar nicht gegen unser Gefühl daß wir Sätze nicht soweit zerlegen können um die Elemente namentlich anzuführen aber wir fühlen daß die Welt aus Elementen bestehen muß. Und es scheint als sei das identisch mit dem Satz die Welt müsse eben sein was sie ist, sie müsse bestimmt sein. Oder mit anderen Worten was schwankt sind unsere Bestimmungen nicht die Welt." (Wittgenstein, 1969, p. 62 [62]) 
proposicional é sempre determinado. Este pressuposto compõe a estrutura conceitual utilizada na dissolução dos problemas filosóficos através da análise lógica da linguagem e permite que afirmemos, de maneira totalmente a priori, que o mundo é constituído por objetos simples.

Desafiamos anteriormente uma maneira mais imediata de entender a relação entre simplicidade e análise, calcada no aspecto decomposicional da tarefa analítica. Este aspecto é bastante evidente no Tractatus e pode ser identificado, por exemplo, na ideia de que a análise parte de proposições mais complexas e termina em proposições elementares. É marcante, nesse contexto, notar que se o filósofo não pode exemplificar proposições elementares, a efetivação desta análise é somente presumida. É sabido que o objeto é o resultado de uma análise decomposicional, mas esta constatação não é, ela mesma, resultante do empreendimento desta análise. A conclusão de que o mundo é composto por elementos simples é defendida nos Notebooks em detrimento da ideia de um objeto infinitamente complexo, com base num pressuposto que compõe a estrutura conceitual na qual a análise tractariana será baseada. A origem deste pressuposto é uma perspectiva de acordo com a qual a linguagem e a realidade compartilham certos aspectos essenciais. Deste modo, sabendo que o sentido proposicional é sempre dado de maneira determinada, é possível inferir que as situações que ocorrem no mundo também o são. Outra maneira de encarar o objeto como "resultado" da análise é ver como a escolha pela simplicidade em detrimento da complexidade infinita não envolve decomposição, mas uma prerrogativa que compõe a estrutura interpretativa conceitual da filosofia do primeiro Wittgenstein em sua relação com o modo transformativo de análise.

A identificação de uma compatibilidade entre a completude da análise infinita e o modo transformativo de análise se dá com base no pressuposto de que o estabelecimento prévio do uso sintático de cada uma das partes da proposição é também uma maneira de requerer determinação para o sentido proposicional. A visão sobre a análise lógica apresentada pelo primeiro Wittgenstein desenvolve aspectos relativos ao seu modo decomposicional enquanto considera a prevalência do modo transformativo. Se a existência do objeto simples está de alguma maneira dada na ideia de análise, devemos entender o peso dado a cada um de seus modos na abordagem wittgensteineana. Esta investigação visa proporcionar um esclarecimento sobre algumas observações tractarianas, como a defesa da existência de uma única análise completa da proposição (T 3.25). Como vimos, é possível conceber a completude da análise sob a perspectiva de diferentes modos de análise. É plausível, portanto, perguntar qual modo de análise está sendo considerado na exigência tractariana 
da análise completa.

\section{2}

\section{Modos de análise no Tractatus}

O tópico da análise lógica pode ser abordado através de dois pontos de vista diferentes no Tractatus. Além de empreender um tipo de análise lógica, a filosofia tractariana expressa também as características que uma tal análise deve possuir. Apesar de o filósofo não ser responsável por encontrar as proposições elementares, o discurso filosófico é, não obstante, capaz de afirmar que a análise lógica da linguagem deve ter um ponto final. Podemos distinguir, portanto, entre a análise que o Tractatus defende ser possível ao declarar suas características através de trabalho filosófico e a análise conceitual através da qual estas características podem ser alcançadas. O analysandum i.e., o objeto a ser analisado - na análise wittgensteineana é a linguagem e seu objetivo é dissolver problemas filosóficos com o uso de um simbolismo lógico que previne a formação de ambiguidades. Este objetivo é alcançado através da diferenciação, calcada num correto entendimento da lógica da linguagem logrado pelo trabalho analítico, entre enunciados que de fato fazem sentido e os que não passam de contrassensos. Em certo sentido, o mundo representado pela linguagem é também objeto da análise, na medida em que se defende a existência de certos aspectos lógicos compartilhados entre ambas as esferas.

A análise tractariana está comprometida com a concepção, herdada da teoria de Russell, de acordo com a qual a linguagem esconde a sua verdadeira forma lógica ( $\mathrm{T}$ 4.0031). Sob esta perspectiva, o alcance da forma lógica proporcionaria o reconhecimento das características essenciais da proposição a partir do ponto de vista lógico correto. Através da distinção entre a forma real da proposição e sua forma aparente, deve ser possível diferenciar proposições significativas de contrassensos. A forma lógica pode ser vista como um resultado da análise que atravessa a aparência enganadora das proposições e fornece o correto entendimento da lógica da linguagem. Dado este panorama, a investigação sobre a maneira como a forma lógica é determinada pode proporcionar um esclarecimento sobre o método de análise desenvolvido no Tractatus.

Para entender como a análise da linguagem alcança a forma lógica da proposição, precisamos resgatar as noções tractarianas de sinal e símbolo, consideradas previamente no segundo capítulo. A versão metodológica do Princípio do Contexto pode ser identificada na ideia de que o reconhecimento de um símbolo depende do contexto de uso significativo de um sinal (T 3.326). A noção de proposição que subjaz esta distinção, fornecida pela estrutura conceitual da teoria da figuração, é baseada na relação de projeção que se 
mantém entre um sinal proposicional e o mundo ( $\mathrm{T}$ 3.12). Uma proposição possui características acidentais, que dizem respeito ao modo de produção do sinal proposicional, e essenciais, que permitem a expressão de seu sentido ( $\mathrm{T}$ 3.34). Um sinal por si só não possui os atributos necessários para veiculação de sentido proposicional caso não seja utilizado como projeção de uma situação.

As confusões que permeiam a filosofia são originadas em situações nas quais um mesmo sinal possui dois símbolos diferentes e, consequentemente, apresenta dois modos de significação distintos ( $\mathrm{T}$ 3.321). Um símbolo, diferentemente de um sinal, não é um aspecto da proposição que pode ser identificado através de nossa percepção sensorial, mas pode ser reconhecido caso observemos o uso significativo da linguagem. A análise lógica deve identificar os aspectos essenciais da proposição e, para tanto, é preciso priorizar um contexto de uso que evite a formação de contrassensos. Para que o simbolismo proposto pelo primeiro Wittgenstein evite equívocos, é preciso que certas condições sejam satisfeitas. Estas condições são apresentadas no aforismo 3.325:

3.325 Para evitar esses equívocos, devemos empregar uma notação que os exclua, não empregando o mesmo sinal em símbolos diferentes e não empregando superficialmente da mesma maneira sinais que designem de maneiras diferentes. Uma notação, portanto, que obedeça à gramática lógica - à sintaxe lógica.

(A ideografia de Frege e Russell é tal notação que não chega, todavia, a excluir todos os erros). ${ }^{17}$

Uma notação que obedece à gramática lógica requer uma restrição específica quanto ao uso de sinais e seus respectivos modos de significação, evitando empregar sinais que designam de maneiras distintas como se estes possuíssem o mesmo símbolo. Um exemplo esclarecedor desse tipo de situação envolve o termo "é", que pode (1) ocorrer como cópula numa oração predicativa, (2) representar o sinal de igualdade e (3) expressar existência enquanto verbo intransitivo, como nos exemplos:

(1) As abelhas são polinizadoras.

(2) O número um é o menor número natural ímpar.

(3) Anjos não existem.

A gênese das "confusões mais fundamentais" está na tendência em achar que as expressões do verbo ser encontradas nos exemplos acima possuem o mesmo modo de significação. A linguagem ordinária, que emprega comumente o mesmo sinal atrelado a símbolos diferentes, deve ser então substituída por uma notação construída com o objetivo de eliminar ambiguidades, evitando assim

${ }^{17}$ Wittgenstein, 2017, p. 149 [60]. 
os problemas. Um sinal, enquanto aspecto unicamente sensível da proposição, só pode determinar uma forma lógica caso seja considerado juntamente à sua aplicação lógico-sintática (T 3.327).

Encontrar a forma lógica é uma tarefa que aparentemente depende do estabelecimento de alguns pressupostos. Para que a análise correspondente possa ser iniciada, é necessário possuir a capacidade de reconhecer os diferentes modos de significação que um mesmo sinal pode possuir nos diferentes contextos possíveis de seu uso. Na determinação da forma lógica apenas o contexto do uso lógico-sintático interessa. Não se trata, portanto, de um uso qualquer da linguagem, mas de um uso logicamente correto, i.e, que observa as regras da sintaxe lógica ${ }^{18}$. De acordo com Phillips ${ }^{19}$, estas considerações levam a um problema de circularidade na tentativa de estabelecer um método de análise lógica no Tractatus. Isto se dá porque a identificação do modo de significação de um sinal pressupõe a diferenciação entre as proposições nas quais um mesmo sinal simboliza de maneiras diferentes e aquelas nas quais isto não ocorre. Esta distinção só pode ser efetivada caso conheçamos as regras da sintaxe lógica que caracaterizam o uso significativo da linguagem. Desta maneira, um conhecimento prévio da lógica da linguagem é necessário para que se reconheça o símbolo no sinal, possibilitando assim a determinação de uma forma lógica. O correto entendimento da lógica de nossa linguagem deveria, contudo, ser o resultado da análise, não seu pressuposto. A possibilidade desta análise encontra-se, consequentemente, baseada naquilo que sua realização pretende alcançar.

A ocorrência desta circularidade é, contudo, apenas aparente. A aparência paradoxal pode ser dissipada através da atenção aos diferentes modos de análise presentes na abordagem tractariana. Phillips argumenta que o assim chamado "paradoxo da análise" tractariana não impede a lida com os problemas filosóficos porque a resolução destes últimos pode ser entendida de duas maneiras:

Eu quero distinguir dois modos de pensar sobre a solução de um problema filosófico. [...] A primeira linha de pensamento é a de que nossa tarefa é alcançar um entendimento correto da lógica das proposições ordinárias. Quando nós alcançamos esse entendimento correto o problema será resolvido. A segunda linha de pensamento é a de que nossa tarefa é corrigir qualquer mal-entendido que produziu a confusão filosófica. Quando nos damos conta de nosso erro, nós entendemos que nosso problema filosófico é uma confusão e, ao fazer isso, resolvemos o problema. ${ }^{20}$

${ }^{18}$ Wittgenstein, 1973, p. 59 apud Phillips, 2007, p. 168 [46].

${ }^{19} 2007$, p. $168-9$ [46].

20"I want to distinguish two ways of thinking about the solution to a philosophical problem. 
A cada um destes meios de dirimir ambiguidades corresponde uma "visão" de análise. No primeiro caso, a tarefa da filosofia consistiria na análise de proposições complexas em função da verdade de proposições elementares, caracterizando o que Phillips denomina uma "visão da análise completa". A concepção denominada "análise clarificatória", correspondente ao segundo caso, requer o esclarecimento de nosso entendimento equivocado sobre a lógica de uma proposição. Apesar de presumir que a efetivação da análise completa acarreta a supracitada clarificação, Wittgenstein parece não exigir sua concretização para a dissolução dos problemas ${ }^{21}$.

Não é difícil identificar o modo resolutivo na visão da análise completa defendida no Tractatus, cuja principal marca é a decomposição de complexos em elementos mais simples. A proposição é concebida como uma função de verdade de proposições elementares ( $\mathrm{T}$ 5), estas últimas formadas pela conexão de nomes ( $\mathrm{T}$ 4.22). No entanto, a defesa da possibilidade da análise completa da proposição não implica necessariamente que o método de análise utilizado na efetiva resolução de confusões filosóficas dê prioridade ao aspecto decomposicional. Como ressaltado anteriormente, se a análise lógica das proposições complexas é a ferramenta a ser utilizada pela filosofia, é difícil entender porque o trabalho lógico-filosófico não pode exemplificar as proposições elementares resultantes desta empreitada. Esta dificuldade pode ser sanada pela constatação de que a análise tractariana apresenta outra faceta, que toma precedência quanto ao modo resolutivo de análise.

A etimologia da palavra "análise", que remonta ao grego antigo e significa "dissolução" ou "separação", origina uma ambiguidade que afeta o uso deste termo na história do pensamento ${ }^{22}$. Comumente, o resultado final da decomposição de um dado analysandum é mais central; entretanto, o processo mesmo de análise envolve outros elementos igualmente importantes, como as ferramentas adequadas ao pretenso trabalho analítico. De acordo com o primeiro Wittgenstein, a filosofia não envolve decomposição e não resulta em nenhuma proposição, mas no esclarecimento lógico dos pensamentos ( $\mathrm{T}$ 4.112).

4.112 O fim da filosofia é o esclarecimento lógico dos pensamentos.

A filosofia não é uma teoria, mas uma atividade.

Uma obra filosófica consiste essencialmente em elucidações.

[...] The first line of thought is that our task is to achieve a correct understanding of the logic of everyday propositions. When we achieve this correct understanding the problem will be solved. The second line of thought is that our task is to correct whatever misunderstanding has produced the philosophical confusion. When we realize our mistake, we understand that our philosophical problem is a confusion and, in so doing, solve the problem." (Phillips, 2007, p. $169[46]$.

${ }^{21}$ Phillips, 2007, p. 171 [46].

${ }^{22}$ Beaney, 2002, p. 54 [4]. 
O resultado da filosofia não são proposições filosóficas, mas é tornar proposições claras.

Cumpre à filosofia tornar claros e delimitar precisamente os pensamentos, antes como que turvos e indistintos. ${ }^{23}$

Este aforismo expressa a ideia de uma análise clarificatória, cujo mote principal é a eliminação de ambiguidades que prejudicam o entendimento da lógica da linguagem. Apesar de a análise completa acarretar igualmente a clarificação pretendida, seu desfecho consiste no alcance de proposições elementares e, portanto, este não pode ser um "resultado da filosofia". O "método correto" para a filosofia envolve um trabalho elucidativo que usa proposições contrassensuais de uma maneira particular:

$6.53 \mathrm{O}$ método correto da filosofia seria propriamente este: nada dizer senão o que se pode dizer; portanto, proposições da ciência natural - ou seja, algo que nada tem a ver com filosofia; e então, sempre que alguém pretendesse dizer algo de metafísico, mostrar-lhe que não conferiu significados a certos sinais em suas proposições. Esse método seria, para ele, insatisfatório - não teria a sensação de que lhe estivéssemos ensinando filosofia; mas esse seria o único rigorosamente correto.

6.54 Minhas proposições elucidam da seguinte maneira: quem me entende acaba por reconhecê-las como contrassensos, após ter escalado através delas - por elas - para além delas. (Deve, por assim dizer, jogar fora a escada após ter subido por ela). mente. $^{24}$

Deve sobrepujar essas proposições, e então verá o mundo correta-

A filosofia, de acordo com o Tractatus, é uma atividade elucidativa que consiste de um único método "rigorosamente correto" para evitar a colocação de um discurso metafísico. Este método consiste em mostrar que a linguagem assim utilizada não cumpre a função de munir o discurso de sentido e que seus sinais não possuem, portanto, significado. Com o uso de elucidações, que são também proposições contrassensuais, Wittgenstein pretende alcançar o objetivo de oferecer uma visão correta do mundo. Para ver o mundo corretamente é preciso ser capaz de identificar o uso significativo da linguagem e, assim, diferenciá-lo de um uso não significativo.

Vimos anteriormente que a discussão sobre as características da análise lógica nos Notebooks considera com atenção a possibilidade de uma análise infinita, i.e., que desvela objetos infinitamente complexos. Conforme avançamos ao Tractatus, identificamos a demanda de que esta análise seja completa e que termine em proposições elementares cujos sinais simples constituintes denotam

${ }^{23}$ Wittgenstein, 2017, p. 167 [60]

${ }^{24}$ Wittgenstein, 2017, p. 261 [60] 
objetos igualmente simples. É possível perguntar, então: por que objetos devem ser ultimamente simples se nada parece "falar contra" a complexidade infinita? A resposta foi também apontada em nossas considerações anteriores: a justificativa para a escolha da simplicidade está calcada no "sentimento" de que, em certo sentido, a linguagem apresenta aspectos essenciais da realidade por ela representada. Deste modo, se o sentido proposicional é sempre determinado, com a realidade deve ocorrer o mesmo.

O modo como a simplicidade é dada na ideia de análise não decorre, portanto, da concretização da análise completa. Outra maneira de encarar o objeto simples como "resultado" da análise é entender que a justificativa para sua formulação jaz nos pressupostos conceituais que compõem a estrutura interpretativa contra a qual a linguagem deve ser analisada. Os três diferentes modos de análise - decomposicional, regressivo e transformativo - podem ser identificados na abordagem do primeiro Wittgenstein. A demanda de uma única e finita análise completa de proposições complexas em proposições elementares no Tractatus, que apresenta o modo decomposicional, é justificada por um aspecto relativo ao modo transformativo, qual seja, a ideia de que somente um ambiente no qual tudo é precisamente determinado pode prevenir as ambiguidades que levam às confusões. Neste sentido, a linguagem ordinária é falha e deve ser substituída por - ou, por assim dizer, "transformada" em - uma linguagem que obedeça às regras mantenedoras da determinação do sentido proposicional.

Com o fim da análise completa é obtida a forma lógica da proposição, cujo alcance permite também a dissolução dos problemas filosóficos. Consequentemente, há um aspecto regressivo na análise completa tractariana, evidenciado na identificação da forma lógica como uma espécie de princípio fundamental que revela a essência da linguagem e do mundo. O esclarecimento sobre o uso significativo da linguagem pode ocorrer, contudo, sem o emprego da análise de uma proposição em função da verdade de proposições elementares, o que mostra que a análise completa não é indispensável para a clarificação lógico-filosófica ${ }^{25}$. Antes de determinar a forma lógica de uma proposição, é necessário que um sinal seja considerado junto ao seu uso significativo. Este uso, por seu turno, equivale à aplicação lógico-sintática da linguagem, regida pelas leis da sintaxe lógica. A análise clarificatória tractariana incorpora também o modo regressivo de análise, pois as regras da gramática ou sintaxe lógica funcionam como princípios utilizados no estabelecimento de um uso "lógico" da linguagem. A principal preocupação deste contexto de uso é manter o caráter determinado do sentido, evitando assim os problemas filosóficos.

${ }^{25}$ Phillips, 2007, p. 172 [46]. 
Consideramos os aspectos da análise lógica esboçada pelo primeiro Wittgenstein com o intuito de entender a afirmação da existência do objeto simples. Por um lado, objetos são resultado da análise porque figuram como significados dos sinais simples que constituem as proposições elementares encontradas na análise completa da linguagem. Existem, contudo, aspectos adicionais da análise lógica a serem considerados. Devido à problemática que envolve a tomada do modo decomposicional, característico da análise completa da proposição, como o método filosófico empregado pelo Tractatus, é plausível buscar uma explicação para o objeto nos outros modos de análise identificados em nossa investigação.

Existe um aspecto da análise clarificatória que se relaciona diretamente com a simplicidade do objeto, concernente à demanda pela determinação do sentido. Como foi visto, esta demanda justifica a escolha da simplicidade em detrimento da complexidade infinita do objeto. Além disso, ambos os postulados dos sinais simples e da análise completa são baseados na mesma exigência:

3.23 O postulado da possibilidade dos sinais simples é o postulado do caráter determinado do sentido. [...]

3.25 Há uma e apenas uma análise completa da proposição.

3.251 A proposição exprime de uma maneira determinada, claramente especificável, o que ela exprime: a proposição é articulada. ${ }^{26}$

A dissolução de problemas filosóficos se dá através de uma análise que possui um caráter transformativo evidenciado na substituição de linguagens utilizadas de maneira ambígua por uma linguagem logicamente estruturada, obediente às regras que evitam ambiguidades e prezam, portanto, pela determinação e a precisão que caracterizam o uso significativo da linguagem. Este parece ser, com efeito, um sentido no qual o Tractatus, de acordo com Cora Diamond, apresenta um tipo particular de metafísica:

Eu preciso primeiro perguntar se há um sentido no qual o Tractatus pode ser descrito como metafísico [...]. Ele é metafísico ao sustentar que é possível para proposições serem reescritas de tal modo que estas relações lógicas estejam todas claramente visíveis, e que, ao reescrevê-las deste modo, quais proposições nossas proposições são, quais combinações de sinais, também estaria claro, assim como estaria o que todas as proposições têm em comum. ${ }^{27}$

${ }^{26}$ Wittgenstein, 2017, p. 144-5 [60].

27 "I need first to ask whether there is a sense in which the Tractatus might be described as metaphysical [...]. It is metaphysical in holding that it is possible for propositions to be rewritten in such a way that these logical relations are all clearly visible, and that, by rewriting them in that way, what propositions our propositions are, what combinations of signs, would also be clear, as would be what all propositions have in common." (Diamond, 1995, p. 18 [10].) 
Ainda de acordo com Diamond, o que há de metafísico na concepção wittgensteineana não é algo de externo à linguagem e ao pensamento e não diz respeito ao conteúdo de nenhuma crença, mas ao estabelecimento de requerimentos de análise lógica. A metafísica do Tractatus consiste, sob esta perspectiva, no "dever" metafísico da análise lógica e da consequente determinação total de sentido ${ }^{28}$.

A exigência wittgensteineana pelo caráter determinado do sentido pode ser entendida como um aspecto basilar de sua concepção metafísica. As regras da gramática ou sintaxe lógica marcam o modo regressivo presente na concepção de análise do primeiro Wittgenstein e podem ser entendidas como certos requerimentos necessários para a transformação acarretada pela análise das proposições. A formulação do objeto tractariano deve ser entendida no contexto do estabelecimento de regras sintáticas responsáveis por garantir a determinação do sentido proposicional. Estas regras não são determinadas pela decomposição de complexos linguísticos ou ontológicos, mas podem ser identificadas através da atenção ao uso significativo da linguagem. Seguindo a ideia de que análise clarificatória é de alguma forma responsável pela constatação da existência de objetos simples, identificamos em sua composição a centralidade dos modos transformativo e regressivo de análise, conjugados na ideia de que um ambiente de total determinação é necessário e distinguível de outros contextos por meio de regras da sintaxe lógica.

A investigação sobre o argumento da substância, empreendida anteriormente no primeiro capítulo, revela que a existência de objetos é postulada como uma condição para que a determinação do sentido proposicional não seja comprometida por uma análise ad infinitum. A demanda pela determinação também é a base para a justificativa da escolha da simplicidade absoluta do objeto em detrimento de sua divisibilidade infinita. O objeto pode ser entendido, desta forma, como resultado da incorporação de diferentes demandas para a garantia da determinação proposicional através da análise clarificatória efetivada no Tractatus. A partir desta abordagem é possível entender o conflito que caracteriza a noção de objeto como um choque entre diferentes exigências fornecidas por meio desta análise.

A possibilidade do estabelecimento de uma forma lógica está condicionada, como visto anteriormente, à capacidade de reconhecer os modos de significação que constituem diferentes signos proposicionais através de variados contextos de uso. Existem, com efeito, aspectos conceituais importantes no Tractatus que são moldados sobre a tomada categórica do Princípio do Contexto como uma condição para a significatividade de nomes (em sua formulação

${ }^{28}$ Diamond, 1995, p. 19-20 [10]. 
semântica) assim como para a possibilidade de determinação da forma lógica (em sua aplicação metodológica). No decorrer deste trabalho, argumentamos que este princípio pode ser encarado no Tractatus a partir de uma formulação ontológica, encontrada na caracterização da forma dos objetos. Através do exame sobre a análise lógica tractariana e o reconhecimento de seu aspecto transformativo, é possível evidenciar o aspecto que torna possível a formulação ontológica do Princípio do Contexto no seguinte pressuposto da armação conceitual que baseia a análise clarificatória: linguagem e mundo são em certo sentido um só.

Objetos são simples porque mundo e linguagem são igualmente determinados. A capacidade de concatenação de um objeto com outros no nexo de um fato atômico é sua característica essencial, assim como a ocorrência no contexto proposicional é um aspecto indispensável, sem o qual o nome falha em ser significativo. Aqui linguagem e mundo são aproximados novamente pois a demanda do Princípio do Contexto, que atua sobre a linguagem, é equivalentemente atribuída à realidade, tornando a existência do objeto dependente de sua aparição em fatos atômicos assim como a significatividade de um nome depende de sua ocorrência no contexto de proposições. O modo como a análise clarificatória é estruturada permite que o objeto carregue traços conflitantes, resultantes do estabelecimento de requesitos lógicos sobre a linguagem que apresentam entre si uma clara tensão. O conflito pode ser observado na despreocupada explicação sobre a independência do objeto em termos de sua alegada dependência quanto ao fato atômico. Os objetos não podem ser decompostos e são, consequentemente, simples, porque compõem a substância do mundo que subsiste independentemente do que ocorre. Enquanto a atribuição da simplicidade está conectada à subsistência independente, a incorporação do Princípio do Contexto na ontologia tractariana, que resulta no conceito de forma dos objetos, torna a substância dependente daquilo que ocorre no mundo.

A tensão se estabelece, deste modo, entre as demandas da simplicidade e do Princípio do Contexto, ambas exigidas pelo funcionamento significativo da linguagem. A postulação dos sinais simples é uma exigência para a determinação do sentido, assim como a existência de objetos simples é condizente com a consequente determinação que deve caracterizar o mundo. As duas carcaterísticas essenciais atribuídas ao objeto, sua simplicidade e sua forma, são postuladas como garantias para a exatidão inerente à linguagem e ao mundo. A contradição estabelecida nessa formulação é oriunda de duas demandas sobre a precisão do sentido alcançadas no contexto da análise clarificatória avançada pelo primeiro Wittgenstein. Sob a perspectiva desta análise é possível explicar como o objeto acaba incorporando um conflito entre o requesito atomista de 
simplicidade e subsistência independente e a exigência holista da dependência ontológica do objeto com relação ao fato atômico.

A explicação aqui pretendida sobre a "natureza" do objeto tractariano é compatível com uma metafísica concebida nos termos defendidos por Cora Diamond na seguinte passagem:

A metafísica do Tractatus é um tipo de metafísica que não envolve o que é indizivelmente o caso fora da linguagem, exceto enquanto sentenças as quais, como pode-se dizer, 'aparentam ser sobre tais coisas', ajudam-nos a entender os requerimentos os quais são internos a uma sentença que possui um uso, i.e., sendo alguma combinação inteiramente determinada de sinais. ${ }^{29}$

Seguindo este mote, o que nos preocupa não é discorrer sobre o objeto enquanto algo indizível que existe fora da linguagem, mas entendê-lo como o resultado do estabelecimento de requerimentos lógicos sobre o uso da linguagem. Esta abordagem é compatível com os aspectos evidenciados no exame da análise clarificatória, notavelmente no tocante à ideia de que o discurso significativo pode ser diferenciado de um discurso contrassensual através da observância de regras gramaticais para um uso logicamente estruturado da linguagem. Simplicidade e forma são dois atributos essenciais de objetos cuja postulação descansa sobre a manutenção de regras sintáticas resultantes da exigência tractariana de exatidão para a linguagem unida à tese fundamental de que discurso e mundo compartilham o mesmo caráter determinado.

Como foi visto, o Princípio do Contexto fregeano é empregado com o intuito de eliminar ambiguidades geradas por concepções filosóficas pouco inspiradas logicamente. Este é, com efeito, o tom geral do empreendimento tractariano, que pretende resolver problemas filosóficos a partir do insight lógico correto. O esclarecimento conceitual proposto pela análise clarificatória depende da obediência do simbolismo às regras da gramática ou sintaxe lógica ( $\mathrm{T}$ 3.325). A recusa do primeiro Wittgenstein em exemplificar objetos é justificada a partir da sua ideia de análise clarificatória, que constitui um esforço elucidativo sobre postulados para a determinação do sentido. Estas regras separam o que faz sentido do que é contrassenso e não podem ser derivadas a partir de uma "regra geral" como a forma geral da proposição pretensamente encontrada no fim da análise completa da linguagem ${ }^{30}$.

29"The metaphysics of the Tractatus is a kind of metaphysics that does not involve what is unsayably the case outside language, except so far as sentences which, as one might say, 'appear to be about such things', help us understand the requirements which are internal to a sentence's having a use, i.e., being some entirely determinate combination of signs." (Diamond, 1995, p. 19 [10].)

${ }^{30}$ Engelmann, 2013, p. 133 [14]. 
O requerimento da existência de objetos é um postulado baseado no correto funcionamento da lógica da linguagem, resultado de um esforço analítico de clarificação que explicita regras gramaticais. Adentramos a natureza do objeto a partir de uma metafísica preocupada com o estabelecimento de requerimentos para um uso significativo do discurso. Desta maneira, identificamos diferentes postulados em sua formulação que podem ser vistos como exemplos de regras para uma sintaxe lógica da linguagem. Para esclarecer, então, a noção de objeto, faz-se necessário um exame um pouco mais detalhado sobre a ideia mesma de uma gramática ou sintaxe lógica.

A noção de gramática é recuperada no decorrer do desenvolvimento filosófico de Wittgenstein, ganhando centralidade nos trabalhos desenvolvidos a partir de seu retorno a Cambridge em 1929. De acordo com pensamentos desenvolvidos a partir deste período, tanto a demanda pela simplicidade quanto o Princípio do Contexto são tomados como regras gramaticais. Exploraremos abordagens que aproximam os objetivos gerais da investigação desenvolvida no Tractatus com aqueles perseguidos por Wittgenstein em momentos posteriores de sua obra. O resultado desta postura é identificar o objeto tractariano como resultado da postulação de regras gramaticais para o uso lógico da linguagem, responsáveis por extinguir a formação de contrassensos. Para chegar satisfatoriamente aos termos desta proposta, é preciso investigar as interpretações já bem estabelecidas na literatura secundária sobre a noção de sintaxe lógica no Tractatus.

\section{3}

\section{Objeto e gramática/sintaxe lógica}

A análise lógico-filosófica oferecida pelo primeiro Wittgenstein pretende lidar com problemas filosóficos oriundos do emprego de um simbolismo inadequado. É possível manejar a dissolução destes problemas pela observação de regras sintáticas que delimitam a esfera do discurso significativo. Como consequência, um uso da linguagem no qual estas regras não vigoram resulta em proposições contrassensuais. As regras gramaticais podem ser tomadas, deste modo, como um conceito fundamental do Tractatus, pois seu papel está diretamente relacionado à distinção, cara à filosofia tractariana, entre o discurso significativo e o contrassensual.

As demarcações semânticas fornecidas pelo Tractatus apresentam o discurso apofântico, que pode ser verdadeiro ou falso, como aquele formado por proposições de pleno direito, as quais efetivamente representam situações no mundo. Uma proposição genuína, enquanto figuração da realidade, é sempre contingente. A verdade ou falsidade de uma figuração é dada através de sua 
comparação com a realidade e não é possível, desta maneira, que existam proposições cuja verdade é dada a priori (T 2.223-5). A bipolaridade é marca essencial do discurso significativo, de tal modo que a proposição deve apresentar sempre um de dois pólos: verdadeiro ou falso. Consequentemente, se uma proposição é sempre verdadeira e não pode, portanto, ser falsa, isto significa que não se trata de uma proposição legítima. O mesmo ocorre, evidentemente, caso uma dada expressão linguística seja sempre falsa.

Tautologias e contradições possuem um status semântico particular na trama tractariana por se tratarem de casos limites da combinação de sinais ( $\mathrm{T}$ 4.466). No Tractatus, toda proposição é uma função de verdade de proposições elementares ( $\mathrm{T}$ 5) e existem grupos distintos de condições de verdade pertencentes às possibilidades de verdade destas proposições. As possibilidades de verdade de proposições elementares são verdadeiro (V), caso o fato atômico representado exista e falso (F) em caso contrário. Para duas proposições elementares $p$ e $q$, estas possibilidades podem ser arranjadas num esquema como o que segue ( $\mathrm{T} 4.31$ ):

\begin{tabular}{l|l}
$p$ & $q$ \\
\hline $\mathrm{V}$ & $\mathrm{V}$ \\
$\mathrm{F}$ & $\mathrm{V}$ \\
$\mathrm{V}$ & $\mathrm{F}$ \\
$\mathrm{F}$ & $\mathrm{F}$
\end{tabular}

Uma proposição complexa é concebida como a expressão da concordância ou discordância com as possibilidades de verdade de proposições elementares ( $\mathrm{T}$ 4.4). Para exprimir concordância, Wittgenstein propõe que a marca "V" seja associada às possibilidades de verdade correspondentes. Quando o contrário ocorrer - isto é, quando não houver concordância entre a proposição e as possibilidades de verdade - a marca estará ausente ( $\mathrm{T}$ 4.43). Se uma regra combinatória é utilizada na determinação da sequência das possibilidades de verdade que ocorrem no esquema, é possível gerar uma terceira coluna que expressa as condições de verdade da proposição. O resultado de uma tal operação pode ser escrito da seguinte forma ( $\mathrm{T} 4.442$ ):

\begin{tabular}{l|l|l}
$p$ & $q$ & \\
\hline $\mathrm{V}$ & $\mathrm{V}$ & $\mathrm{V}$ \\
$\mathrm{F}$ & $\mathrm{V}$ & $\mathrm{V}$ \\
$\mathrm{V}$ & $\mathrm{F}$ & \\
$\mathrm{F}$ & $\mathrm{F}$ & $\mathrm{V}$
\end{tabular}

A tabela acima é tomada como um exemplo de sinal proposicional, este último concebido como o resultado da coordenação entre a marca "V" e as possibilidades de verdade de proposicões elementares. 
Esta construção notacional, a qual Wittgenstein nomeia "notação-ab"31, é considerada uma regra simbólica suficiente para identificar a verdade ou falsidade de proposições lógicas ${ }^{32}$. É preciso, no entanto, proceder com cautela na atribuição de valores de verdade a proposições lógicas, pois estas últimas são consideradas "casos especiais" devido ao modo através do qual sua verdade é estabelecida. Nenhuma proposição, enquanto figuração lógica do mundo, pode ter sua verdade reconhecida tão somente a partir de si mesma (T 2.224); "proposições" lógicas, por outro lado, funcionam de maneira diferente:

Quanto ao que tautologias realmente são, contudo, eu mesmo ainda não sou capaz de dizer mais claramente, mas tentarei dar uma explicação aproximada. É a peculiar (e mais importante) marca de proposições não-lógicas que não se é capaz de reconhecer sua verdade a partir do sinal proposicional por si só. Se eu digo, por exemplo, 'Meier é estúpido', você não pode dizer ao olhar para essa proposição se ela é verdadeira ou falsa. Mas as proposições da lógica - e apenas elas possuem a propriedade de que sua verdade ou falsidade, como possa ser o caso, acha sua expressão no próprio sinal para a proposição. ${ }^{33}$

As proposição "não-lógicas" às quais Wittgenstein se refere nesta carta a Russell datada de novembro ou dezembro de 1913, são aquelas que podem ser verdadeiras ou falsas e não podem ter seu valor de verdade estabelecido de antemão. Proposições lógicas configuram casos extremos dos grupos possíveis de condições de verdade relativos às possibilidades de verdade de proposições elementares. Uma proposição é uma tautologia, i.e., suas condições de verdade são tautológicas, caso seja verdadeira para todas as possibilidades de verdade de proposições elementares; da mesma maneira, caso a proposição seja falsa para todas as possibilidades, temos uma contradição ( $\mathrm{T}$ 4.46).

Proposições da lógica não são consideradas proposições no sentido completo do termo porque não cumprem o papel de representar situações que podem ou não ocorrer no mundo. Além disso, proposições genuínas são bipolares e sua verdade não pode ser reconhecida na proposição ela mesma, enquanto o reconhecimento da verdade de proposições lógicas se dá através do próprio sinal. Tautologias e contradições não cumprem o requesito da bipolaridade e não podem ser, portanto, significativas: trata-se de um discurso sem sentido

${ }^{31}$ cf. Wittgenstein e McGuinness, 2008, p. 50 e 53 [68].

${ }^{32}$ De acordo com Dreben e Floyd (1991, p. 32 [12]), a notação wittgensteineana é essencialmente equivalente ao método hodierno de tabelas de verdade.

33" As to what tautologies really are, however, I myself am not yet able to say quite clearly but I will try to give a rough explanation. It is the peculiar (and most important) mark of non-logical propositions that one is not able to recognize their truth from the propositional sign alone. If I say, for example, 'Meier is stupid', you cannot tell by looking at this proposition whether it is true or false. But the propositions of logic - and only they - have the property that their truth or falsity, as the case may be, finds its expression in the very sign for the proposition." (Wittgenstein e Mcguinness, 2008, p. 58 [68].) 
[sinnlos] (T 4.461). Para que uma proposição seja considerada uma combinação lógica determinada de sinais, é preciso que esta corresponda a uma ligação lógica de objetos determinada; deste modo, proposições que são verdadeiras para todas as situações não podem ser combinações de sinais porque não correspondem a uma conexão determinada de objetos ( $\mathrm{T}$ 4.466).

Proposições lógicas não são figurações da realidade porque não logram sucesso na representação de uma situação possível e veiculam um discurso vazio de sentido ( $\mathrm{T}$ 4.462). Ainda assim, este tipo de proposição está essencialmente conectado à natureza do simbolismo ( $\mathrm{T}$ 4.4611). Como consequência, o discurso carente de sentido [sinnlos] não pode ser confundido com meros contrassensos [unsinnig], cuja ocorrência prejudicial deve ser excluída pela adoção de um simbolismo logicamente correto. É interessante notar que a postulação de verdades lógicas somente é possível na medida em que uma notação satisfatória pode ser postulada ( $\mathrm{T}$ 6.1223). Proposições da lógica não descrevem uma situação particular, mas possuem o distinto papel de descrever ou representar a estrutura lógica do mundo:

6.124 As proposições lógicas descrevem a armação do mundo, ou melhor, representam-na. Não "tratam" de nada. Pressupõem que nomes tenham significado e proposições elementares tenham sentido: e essa é sua ligação com o mundo. É claro que algo sobre o mundo deve ser denunciado por serem tautologias certas ligações de símbolos - que têm essencialmente um caráter determinado. É isso que é decisivo. [...] $\mathrm{Na}$ lógica, só o que não é arbitrário se exprime: isso quer dizer, porém, que na lógica nós não exprimimos, com a ajuda dos sinais, o que queremos, mas o que enuncia na lógica é a própria natureza dos sinais necessários por natureza: se conhecemos a sintaxe lógica de uma notação qualquer, já estão dadas então todas as proposições da lógica. ${ }^{34}$

A caracterização das proposições no Tractatus lida, como pode ser observado, com uma noção de descrição ou representação tomada em ao menos dois sentidos. Por um lado, proposições lógicas são desprovidas de sentido justamente porque não descrevem uma situação particular; por outro, seu status semântico permite que assumam um papel descritivo tomado num sentido mais amplo concernente à estrutura essencial da realidade.

Uma informação importante que ocorre no aforismo 6.124 é a necessidade do conhecimento da sintaxe lógica de uma notação para que estejam dadas todas as proposições da lógica. O papel das regras da gramática ou sintaxe lógica é, desta maneira, central na demarcação tractariana entre proposições significativas, proposições lógicas e contrassensos. O conhecimento da sintaxe lógica está, com efeito, diretamente conectado ao nosso conhecimento sobre

\footnotetext{
${ }^{34}$ Wittgenstein, 2017, p. 242-3 [60].
} 
o modo como cada sinal individual significa ( $\mathrm{T}$ 3.334). A importância das regras sintáticas na estratificação semântica tractariana pode ser observada ao considerarmos a seguinte explicação de Peter Hacker:

Todas as proposições genuínas são empíricas e contingentes. O caso limite de proposições com sentido são tautologias e contradições. Elas não violam nenhum princípio da sintaxe lógica, mas elas não figuram um possível fato atômico de um conjunto de possibilidades. [...] Tais proposições lógicas carecem de sentido mas não são contrassensos. Elas são sinnlos mas não unsinnig. Contrassenso, por outro lado, é uma característica não de proposições degeneradas, mas de pseudoproposições. Pseudo-proposições contrassensuais violam as regras da sintaxe lógica. Como proposições sem sentido elas dizem nada. Mas diferentemente das proposições sem sentido elas não mostram nada sobre o mundo, nem sobre sua forma nem sobre seu conteúdo. ${ }^{35}$

De acordo com Hacker, contrassensos e proposições sem sentido são semelhantes porque ambos não dizem nada sobre o mundo, mas carregam uma importante diferença. Sob esta perspectiva, contrassensos são resultado de usos da linguagem que vão de encontro às regras da sintaxe lógica, enquanto as proposições lógicas, as quais também carecem de sentido, são utilizadas de acordo com estas regras e, deste modo, são capazes de mostrar algo sobre o mundo.

Apesar de afirmar que proposições contrassensuais não mostram nada sobre a forma ou o conteúdo do mundo, Hacker prossegue com a proposta de uma distinção interna ao domínio daquilo que é contrassensual. Contassensos evidentes são aqueles imediatamente identificáveis, como é o caso da expressão "é o bem mais ou menos idêntico ao belo?" 36 ; contrassensos disfarçados, por sua vez, violam as regras da sintaxe lógica de uma maneira mais sutil, imiscuída na linguagem ordinária, como acontece quando filósofos tentam dizer o que só pode ser mostrado. Os contrassensos disfarçados podem ainda ser divididos em iluminadores e enganadores, cabendo aos primeiros a função de proporcionar ao leitor atento uma apreensão daquilo que é mostrado por proposições nãofilosóficas. Formas gramaticais obscurecem a sintaxe lógica da linguagem, esta última entendida como um conjunto de princípios que espelham as condições de possibilidade da representação relativas à natureza essencial de qualquer

35"All genuine propositions are empirical and contingent. The limiting case of propositions with sense are tautologies and contradictions. They do not violate any principles of logical syntax, but they do not picture a possible state of affairs out of a range of possibilities. [...] Such logical propositions lack sense but they are not nonsense. They are sinnlos but not unsinnig. Nonsense, on the other hand, is a feature not of degenerate propositions, but of pseudo-propositions. Nonsensical pseudo-propositions violate the rules of logical syntax. Like senseless propositions they say nothing. But unlike senseless propositions they show nothing about the world, neither about its form nor about its content." (Hacker, 1986, p. 18 [31].)

${ }^{36}$ Hacker, 1986, p. 18 [31]. 
simbolismo possível ${ }^{37}$. A falha em entender a lógica da linguagem leva a contrassensos enganadores, engendrados na ilusão de que aquilo que é mostrado pode ser, de alguma forma, colocado em palavras de modo a formar um discurso significativo.

A posição de Hacker pode ser acomodada na distinção, apresentada por James Conant, entre as concepções substancial e austera sobre a noção de contrassenso. Conant argumenta contra uma leitura do Tractatus concebida nos seguintes termos:

Num esquema mais amplo, o tipo de leitura de Wittgenstein que eu tenho em mente pode ser colocado como se segue: Wittgenstein procura mostrar que proferimentos de metafísicos são contrassensos ao expô-los como sendo logicamente (ou conceitualmente) falhos, onde estas falhas devem ser traçadas a infrações especificáveis sobre as condições do discurso significativo. [...] Se o primeiro trabalho de Wittgenstein está sob discussão, será dito que estas infrações surgem através de violações dos "princípios da sintaxe lógica" [...]..$^{38}$

Leituras como as de Peter Hacker, que tomam contrassensos como resultado de violações das regras da sintaxe lógica, atribuem a Wittgenstein o que Conant chama de concepção substancial de contrassenso. Esta concepção apresenta uma distinção, equivalente àquela feita por Hacker, entre meros contrassensos (ou contrassensos evidentes) e contrassensos substanciais (ou contrassensos disfarçados iluminadores). Enquanto no primeiro caso as expressões linguísticas consideradas não veiculam pensamento algum, no segundo temos "ingredientes inteligíveis combinados de maneira ilegítima" ${ }^{39}$, de uma tal maneira que o resultado da combinação é um pensamento logicamente incoerente. A concepção austera defendida por Conant, a qual caracteriza a assim chamada leitura resoluta do Tractatus, defende que há somente meros contrassensos.

A crítica de Conant é focada na ideia, enfatizada pela concepção substancial, de que sinais podem ser utilizados de uma maneira que viole as regras da sintaxe lógica. Uma contravenção às regras sintáticas é definida na noção substancial como um uso logicamente ilegítimo da linguagem que, de alguma maneira, atravessa os limites do sentido ${ }^{40}$. Como consequência, a origem do contrassenso jaz na tentativa de combinar termos de uma maneira proibida

${ }^{37}$ Hacker, 1986, p. 19 [31].

38 "In broadest outline, the sort of reading of Wittgenstein I have in mind might be put as follows: Wittgenstein seeks to show that the utterances of metaphysicians are nonsense by exposing them to be logically (or conceptually) flawed, where these flaws are to be traced to specifiable infringements upon the conditions of meaningful discourse. [...] If Wittgenstein's early work is under discussion, it will be said that these infringements arise through violations of 'the principles of logical syntax' [...]." (Conant, 2001, p. 13 [7].)

${ }^{39}$ Conant, 2001, p. 14 [7], minha tradução.

${ }^{40} \mathrm{~A}$ argumentação de Conant toma como exemplo a concepção esboçada em Baker e Hacker (1985, p.30-40 e 55 apud Conant 2001, p. 38). 
por um princípio gramatical. O ponto da argumentação de Conant é mostrar que não é possível identificar a categoria lógica ou gramatical de um termo fora do contexto de uma combinação legítima ${ }^{41}$. Ao contrário do que pretende a concepção substancial, a "fonte" da formação de contrassensos não tem relação com violações de regras sintáticas, mas com nossa falha em atribuir significados às expressões utilizadas ${ }^{42}$. Esta falha diz respeito à ausência de uma determinação arbitrária prévia, não à impermissibilidade de qualquer símbolo ( $\mathrm{T}$ 5.473), pois não é possível atribuir um sentido errôneo a nenhum sinal ( $\mathrm{T}$ $5.4732)$.

De fato, a ideia de que violações gramaticais são a origem da formação de contrassensos, implicada pela concepção substancial, carece de base textual: em nenhum momento Wittgenstein fala, ao menos explicitamente, em tais termos. Ainda assim, Hacker argumenta que apesar de não tratar explicitamente de contravenções à regras sintáticas, o aforismo 3.325 afirma que expressões são utilizadas de acordo com a sintaxe lógica numa notação logicamente correta e é impossível conceber esta situação sem admitir a possibilidade de usos contraventores $^{43}$. Em outras palavras, é impossível usar uma expressão de acordo com uma regra sintática caso não seja possível utilizá-la em desacordo com esta regra. Embora a interpretação de Hacker soe razoável, sua conclusão parece ir além daquilo que está realmente escrito no aforismo que baseia sua argumentação.

Como nota Cora Diamond ${ }^{44}$, o que encontramos no aforismo 3.325 é uma referência implícita a notações que desobedecem as regras da gramática ou sintaxe lógica ao permitirem (1) que o mesmo sinal possua símbolos diferentes e (2) que sinais que possuem modos de significação diferentes sejam empregados como se possuíssem o mesmo símbolo. É preciso, portanto, proceder cuidadosamente ao falar sobre violações da sintaxe lógica, pois as condições que o simbolismo não pode deixar de observar caso pretenda coadunar com a sintaxe não são elas mesmas regras gramaticais:

O contraste que é central para o 3.325 é entre linguagens simbólicas que permitem certas possibilidades de confusão filosófica e linguagens simbólicas que impedem tais possibilidades. O fato de que a linguagem ordinária não é governada pela sintaxe lógica não implica que a linguagem, ou o uso de sinais em modos múltiplos e possivelmente confusos, de fato contrarie quaisquer regras da sintaxe lógica.

Uma regra pertencente à notação como um todo, especificando que ela não deveria ser empregada levianamente pela introdução de

${ }^{41}$ Conant, 2001, p. 40 [7].

${ }^{42}$ Conant, 2001, p. 53 [7].

${ }^{43}$ Hacker, 2003, p. 13 [32].

${ }^{44} 2005$, p. 79 [11]. 
novos usos, não é algo 'dado' com o uso de sinais particulares, e é bem diferente do que Wittgenstein quis dizer por 'regras da sintaxe lógica' ${ }^{45}$

A explicação de Diamond é pertinente na medida em que preserva o importante dito tractariano de que as proposições da linguagem ordinária encontram-se logicamente em perfeita ordem ( $\mathrm{T}$ 5.5563). Neste sentido, usos da linguagem que empregam o mesmo sinal para símbolos diferentes não violam, estritamente falando, uma regra sintática que rege um sinal específico, mas uma regra atribuída a uma notação como um todo.

A ideia de que a linguagem ordinária está em perfeito ordenamento lógico pode ser entendida como uma expressão da concepção de análise herdada de Russell, segundo a qual a linguagem esconde sua verdadeira estrutura lógica. Esta observação é importante para a caracterização da análise clarificatória tractariana, cujo objetivo é evitar a ambiguidade inerente à linguagem ordinária através da postulação de uma notação claramente determinada. A transformação ou substituição pretendida por esta análise não implica a separação entre um simbolismo que segue as regras da sintaxe lógica e outro que as viola. A diferença entre a linguagem ordinária e uma notação obediente à sintaxe é a perspicuidade que esta última possui e que permite que a estrutura lógica subjacente à primeira seja evidenciada ${ }^{46}$. A obediência a esta sintaxe lógica deve também ser entendida sob a luz de exigências que não são gramaticais, postuladas com o único objetivo de preservar um ambiente de total determinação.

A interpretação sobre a noção de contrassenso é um marco divisor entre a leitura tradicional do Tractatus, atribuída a Peter Hacker, e a leitura resoluta esposada por Conant e Diamond. A interpretação resoluta defende não existirem distinções lógicas interiores à ideia de contrassenso, de uma tal maneira que não é possível atribuir a uma classe específica a função de mostrar o que quer que seja. A abordagem de Hacker, que entende existirem contrassensos iluminadores capazes de revelar algo que não pode ser dito em palavras através de violações de regras da sintaxe lógica, é tomada por Diamond como resultado de uma atitude vacilante que não leva totalmente a sério a doutrina tractariana. Um aspecto desta abordagem, defendido explicitamente por Hac-

\footnotetext{
45"The contrast which is central for 3.325 is between sign-languages that open up certain possibilities of philosophical confusion and sign-languages that close off such possibilities. The fact that ordinary language is not governed by logical syntax does not imply that the language, or the use of signs in multiple and possibly confusing ways, actually contravenes any rules of logical syntax.[...]

A rule belonging to the notation as a whole, specifying that it was not to be mucked about by introduction of new uses, is not something 'given' with the use of the particular signs, and is quite different from what Wittgenstein meant by 'rules of logical syntax'." (Diamond, 2005 , p. 80 e 81 [11].)

${ }^{46}$ Conant, 2001, p. $46[7]$.
} 
ker, consiste em atribuir a Wittgenstein a ideia da existência de categorias ontológicas fixadas objetivamente e independentes de nosso discurso, as quais são espelhadas na linguagem pela sintaxe lógica ${ }^{47}$.

A proposta de Peter Hacker apresenta a sintaxe lógica como uma noção combinatorial que rege as possibilidades de concatenação de nomes, os quais espelham a forma dos objetos por eles nomeados:

Conhecer um objeto é conhecer todas as suas possíveis ocorrências em estados de coisas, i.e., suas propriedades internas (TLP, 2.0123 f.). A sintaxe lógica de um nome deve espelhar a forma do objeto que ele nomeia. Pois nomes também possuem forma e conteúdo. Seu conteúdo é seu significado. Sua forma é suas possibilidades combinatórias lógico-sintáticas. Isso corresponde precisamente às possibilidades combinatórias metafísicas do objeto que é o conteúdo do nome. Assim como as possibilidades combinatórias de um objeto constituem seu tipo ontológico, assim também as possibilidades combinatórias gramaticais de um nome constituem sua categoria lógico-sintática. ${ }^{48}$

Contrassensos são formados, sob a perspectiva de Hacker, quando nossa linguagem constrói sentenças que ferem as possibilidades combinatoriais de objetos espelhadas por nomes. Contudo, é preciso ter cuidado ao considerar a ideia de que nomes espelham a forma dos objetos. Hacker afirma que nomes também possuem forma e conteúdo, mas uma tal afirmação não é explicitamente colocada no Tractatus. Sabemos que nomes ou sinais simples possuem objetos simples como significado. As noções de forma e conteúdo são, contudo, atribuídas somente à substância (T 2.024-5) e à variáveis proposicionais ou expressões ( T 3.31), cujo significado não consiste em objetos, mas em classes de proposições. Dizer sobre os objetos que estes possuem forma e conteúdo não é suficiente para inferir que nomes espelham sua forma.

A forma de um objeto, espelhada na linguagem como forma de um nome próprio, é entendida como um conjunto de possibilidades combinatórias que constitui o seu tipo ontológico. A tratativa sobre possibilidades combinatoriais é, de fato, uma marca da noção de forma dos objetos. É possível entender esta noção ao menos sob duas perspectivas diferentes. Na visão de Hacker, a forma deve ser entendida como a totalidade das possibilidades combinatórias que são dadas na natureza mesma do objeto. Esta leitura é condizente com o

${ }^{47}$ Diamond, 1996, p. 194 [10].

48"To know an object is to know all its possible occurrences in states of affairs, i.e. its internal properties (TLP, 2.0123 f.). The logical syntax of a name must mirror the form of the object which it names. For names too have both form and content. Their content is their meaning. Their form is their logico-syntactical combinatorial possibilities. This corresponds precisely to the metaphysical combinatorial possibilities of the object that is the content of the name. Just as the combinatorial possibilities of an object constitute its ontological type, so too the grammatical combinatorial possibilities of a name constitute its logico-syntactical category." (Hacker, 1986, p. 20 [31].) 
aforismo 2.0123, que diz que todas as ocorrências possíveis de um objeto em fatos atômicos devem fazer parte de sua natureza. Contudo, a caracterização da forma dos objetos encontrada no aforismo 2.0141 não fala sobre ocorrências possíveis, mas sobre a própria possibilidade da ocorrência. A perspectiva desenvolvida em nossas discussões anteriores trata essa noção de possibilidade nos seguintes termos: todo objeto é um constituinte possível de fatos atômicos e é impossível concebê-lo fora desta possibilidade, i.e., é impossível que um objeto não possa ocorrer em fatos atômicos. Sob esta perspectiva, a forma dos objetos não é um conjunto de ocorrências possíveis, mas a característica essencial a um objeto de possível aparição em fatos atômicos.

Há também dois sentidos a partir dos quais o espelhamento do mundo na linguagem pode ser abordado. O primeiro está mais diretamente associado à teoria da figuração tractariana e pode ser evidenciado na concepção da proposição como o reflexo de uma situação no mundo. A proposição é encarada como uma imagem ou retrato do mundo porque espelha a sua forma lógica, de uma tal maneira que seu alcance por meio de uma análise linguística revela um aspecto essencial da realidade. Este é um importante sentido no qual um nome não pode ser concebido, pois um sinal simples não é, como uma proposição, a imagem de algo, mas um substituto para o objeto (T 3.22). No Tractatus, Wittgenstein é enfático ao afirmar que nomes e proposições não podem ser tratados como noções equivalentes (T 3.144, 3.221). Deste modo, não cabe ao nome a função de espelhar a forma do objeto ao qual se refere.

Todavia, a ideia do espelhamento pode ser considerada num sentido mais amplo que pode ser harmonizado com a perspectiva segundo a qual o nome espelha a forma dos objetos. Linguagem e realidade estão conectadas através do vínculo essencial dado na representação linguística. Esta aproximação pode ser vista tanto na conexão mesma entre figuração e figurado quanto nos aspectos essenciais que devem ser compartilhados pelos dois âmbitos para que esta representação seja possível. Para o objeto, ter uma forma equivale à posse da característica essencial de possível ocorrência em fatos atômicos. O nome que o representa possui um traço essencial análogo que diz respeito à sua significatividade, esta última condicionada à sua ocorrência no nexo proposicional. Como consequência, o nome pode "espelhar" a forma dos objetos porque a linguagem significativa deve ser regida pelo Princípio do Contexto e a dependência que este último atribui a nomes é aparentada àquela atribuída aos objetos pela noção de forma.

As regras da sintaxe lógica são tomadas por Hacker como limites para a esfera do dizível no contexto de uma abordagem realista que, nas palavras de Diamond, pressupõe "a ideia de um reino de necessidades metafísicas" conce- 
bida de uma maneira incompatível com a doutrina tractariana. Contrassensos iluminadores, os quais possuem a função de expressar algo inefável que não pode ser dito em palavras, são formulados sobre o pressuposto de que violações de regras sintáticas levam à declaração de características necessárias da realidade que só podem ser mostradas. De acordo com Diamond, esta abordagem é vacilante porque a doutrina tractariana exige que a tentativa de defender um discurso metafísico seja sempre fadada ao fracasso ${ }^{49}$. A tendência vacilante da postura de Hacker, apontada por Diamond, pode ser observada na caracterização do empreendimento tractariano como uma espécie de "último ato" da metafísica, um esforço justificável que conclui a ilegitimidade de qualquer tendência metafísica análoga ${ }^{50}$. Esta perspectiva acarreta uma "estranha conspiração metafísica" no trabalho do primeiro Wittgenstein ${ }^{51}$, cuja filosofia apregoa a inautenticidade de qualquer discurso metafísico e recomenda silêncio sobre um âmbito que supostamente não pode ser alcançado pela linguagem: aparentemente, devemos aceitar uma doutrina metafísica enquanto afirmamos, através desta própria, que nenhuma doutrina metafísica possui legitimidade.

Intérpretes como Cora Diamond entendem que devemos levar a sério a ideia de que a escada deve ser utilizada e jogada fora como requerido pelo aforismo 6.54, afirmando que posturas como as de Hacker acovardam-se diante da ideia de largá-la e permanecem com as mãos firmemente agarradas a ela ${ }^{52}$. A interpretação resoluta não admite que as declarações escritas no Tractatus revelam algum tipo de pensamento inexprimível, pois não há diferentes tipos de contrassenso. Não há uma necessidade metafísica escondida na frase "Existe uma buggle-wuggle" e, do mesmo modo, não devemos esperar encontrá-las na declaração igualmente contrassensual "Existe uma forma fixa do mundo". A leitura resoluta procura seguir à risca o limite estabelecido pela filosofia tractariana, respeitando o silêncio exigido pela máxima "sobre aquilo de que não se pode falar, deve-se calar"53. De acordo com Diamond o foco não deve ser uma metafísica que o Tractatus não possui, mas sim o "dever" metafísico da análise - a metafísica diz respeito não a conteúdos de crenças, mas ao estabelecimento do requisito da análise lógica ${ }^{54}$.

Existe, no entanto, um ponto comum às duas posturas, concernente à identificação do objetivo final da filosofia enquanto tarefa iluminadora ou clarificatória. Hacker reconhece que Wittgenstein não usa a terminologia "contrassenso iluminador", mas afirma que seus contrassensos elucidam ao

\footnotetext{
${ }^{49}$ Diamond, 1996, p. 194-5 [10].

${ }^{50}$ Hacker, 1986, p. 26-7 [31].

${ }^{51}$ cf. Engelmann, 2018, p. 596 [15].

${ }^{52}$ Diamond, 1996, p. 194 [10].

${ }^{53}$ Wittgenstein, 2017, p. 261 [60].

${ }^{54}$ cf. Diamond, 1996, p. 19-20 [10].
} 
proporcionar o ponto de vista lógico a partir do qual podemos ver o mundo corretamente e que possibilita o reconhecimento das proposições filosóficas como contrassensuais ${ }^{55}$. O ponto de ruptura entre as duas leituras está na discordância sobre a origem da clarificação que, de acordo com Hacker, jaz em aspectos essenciais da realidade que são veiculados por um tipo de contrassenso logicamente privilegiado. A crítica resoluta sobre a inviabilidade da ideia de violação das regras da sintaxe que baseia a noção substancial de contrassenso é compatível com as características que tangem os modos de análise desenvolvidos no Tractatus. Se entendermos as regras gramaticais da linguagem como um reflexo das possibilidades combinatoriais de objetos, é claro que um conhecimento pleno destas é uma consequência do fim da análise completa da proposição. Como nomes próprios são sinais simples cuja concatenação constitui as proposições elementares reveladas no fim da análise completa, não é possível evitar o paradoxo da análise tractariana porque o conhecimento da sintaxe lógica é encarado tanto como a descoberta final do processo de análise como um requesito para que esta análise possa ser empreendida.

A proposta de Conant procura lançar luz sobre o sentido no qual a linguagem ordinária é transformada pela tarefa clarificatória executada via elucidações e com assistência da sintaxe lógica. Esta transformação não pode ser encarada como uma modificação do caráter lógico daquilo que é dito, mas como uma forma de tornar explícita a estrutura lógica implícita na linguagem ${ }^{56}$. A concepção defendida por Hacker, apesar de seu apelo metafísico, procura desenvolver um aspecto clarificatório explicitamente atribuído a contrassensos em sua função elucidativa. Segundo Conant, a tarefa central daquele que elucida é levar ao reconhecimento de contrassensos:

A tarefa para o elucidador tractariano é antes "demonstrar ao [interlocutor] que ele não deu nenhum significado a certos sinais em suas proposições" (§6.53), que a "proposição" é somente aparentemente substancialmente contrassensual. A elucidação somente acaba quando o interlocutor chega ao ponto no qual ele é capaz de reconhecer isso por conta própria. ${ }^{57}$

Esta observação chama nossa atenção ao modo como o aforismo 6.53 equaciona o método correto da filosofia com o reconhecimento de contrassensos. Contudo,

${ }^{55}$ Hacker, 1986, p. 26 [31].

${ }^{56}$ Conant, 2001, p. 47 [7].

57" The task for the Tractarian elucidator is rather 'to demonstrate to [the interlocutor] that he has given no meaning to certain signs in his propositions' (§6.53), that the 'proposition' is only apparently substantially nonsensical. The elucidation is only at an end when the interlocutor arrives at the point at which he is able of his own accord to acknowledge this." (Conant, 2001, p. 58 [7].) 
existe uma condição para que este reconhecimento possa ocorrer, a qual deve ser considerada com igual atenção. A exposição de Hacker, ao apontar que a possibilidade do reconhecimento de contrassensos descansa sobre o alcance de uma correta visão de mundo, é mais condizente com a tratativa sobre elucidações que ocorre no aforismo 6.54:

Minhas proposições elucidam desta maneira: quem me entende acaba por reconhecê-las como contrassensos, após ter escalado através delas - por elas - para além delas. (Deve, por assim dizer, jogar fora a escada após ter subido por ela).

Deve sobrepujar [überwinden] essas proposições, e então verá o mundo corretamente. ${ }^{58}$

De acordo com o texto, as elucidações são reconhecidas como contrassensos quando a "escalada" já ocorreu e já alcançamos o ponto de vista que nos permite jogar a escada fora. Desta forma, o reconhecimento de contrassensos não é o objetivo final da elucidação, mas o seu modus operandi. Nós reconhecemos e sobrepojuamos as pseudoproposições da filosofia com o intuito de ver o mundo corretamente.

A noção de sintaxe lógica está conectada à discussão sobre a aplicação metodológica do Princípio do Contexto na identificação dos modos de significação dos sinais. Um símbolo ou modo de significação diz respeito a um emprego lógico-sintático que só pode ser identificado caso atentemos ao uso significativo da linguagem - um uso que obedece às leis da sintaxe lógica. Na leitura de Conant, um exame sobre o aforismo 3.326, de acordo com o qual a atenção quanto ao uso significativo é necessária para o reconhecimento do símbolo no sinal, fala contra a ideia de que considerações sobre uso não desempenham papel nenhum no estabelecimento do significado de uma expressão linguística no Tractatus. De acordo com esta leitura, a noção de uso desempenha um papel fundamental na explicação do primeiro Wittgenstein sobre a determinação do significado de nomes e proposições, pois o ponto principal dos aforismos 3.3-3.344 é mostrar que o significado de um nome é fixado pelo seu uso em proposições significativas ${ }^{59}$.

O foco de Conant no reconhecimento de contrassensos ofusca uma pergunta que se coloca naturalmente: o que é necessário para que o objetivo da elucidação seja alcançado, i.e., para que o interlocutor seja capaz de reconhecer contrassensos? Esta pergunta está diretamente relacionada a dois problemas lógicos concernentes ao simbolismo que, de acordo com Russell, interessam ao Tractatus. O primeiro envolve as condições para que combinações de símbolos

\footnotetext{
${ }^{58}$ Wittgenstein, 2017, p. 261 [60].
}

${ }^{59}$ Conant, 2001, p. 28-9 [7]. 
façam sentido e não sejam contrassensos; o segundo, as condições para que estas combinações tenham um único sentido. A capacidade de reconhecer um contrassenso depende da identificação das condições que perfazem a significatividade da linguagem. Uma linguagem logicamente perfeita deve possuir dois aspectos centrais: (i) regras da sintaxe que previnem contrassensos e (ii) símbolos que sempre possuem um significado único e definido ${ }^{60}$. Estes aspectos dizem respeito, respectivamente, aos modos de análise regressivo e transformativo que constituem a análise clarificatória tractariana.

A interpretação empreendida por Conant, apesar de fornecer esclarecimentos importantes sobre a transformação acarretada pela clarificação elucidativa, carece de um tratamento mais atento à própria noção de sintaxe lógica. As demandas (i) e (ii) acima são ambas concebidas com o objetivo de eliminar a ambiguidade nociva do discurso contrassensual. Nesse sentido, é notável que às regras sintáticas seja relegada a mera "assistência" na busca pela transparência do que era antes nebuloso e indistinto ${ }^{61}$. Talvez como uma consequência da fixação na necessidade do silêncio e no reconhecimento de contrassensos como método filosófico, a leitura resoluta assume a existência de uma estrutura lógica subjacente à linguagem ordinária na análise clarificatória mas não fornece nenhuma explicação positiva sobre a natureza das regras sintáticas do Tractatus.

A abordagem elucidante de Marie McGuinn, proposta como uma alternativa às leituras tradicional e resoluta, fornece uma explicação sobre a sintaxe lógica que dá centralidade à sua conexão com o Princípio do Contexto e com a noção de uso. A motivação para esta abordagem é a ideia de que deve haver um modo de mostrar que o Tractatus busca alcançar insights filosóficos sobre a natureza da proposição e da lógica sem que haja necessidade de admitir uma teoria sobre a conexão entre linguagem e mundo dada por meio de proposições contrassensuais. A interpretação de McGuinn é descrita como uma tentativa de mostrar que o trabalho tardio de Wittgenstein é um desenvolvimento das ideias que permeiam sua primeira filosofia:

A interpretação que se segue é uma tentativa de dar sentido a essa ideia de que as Investigações Filosóficas são, num sentido importante, um desenvolvimento das ideias do Tractatus. [...]

Assim, o movimento que o segundo Wittgenstein faz para longe da ideia de que o significado de uma palavra é algo que é correlacionado a ela, e em direção à ideia de que o significado de uma palavra é seu

${ }^{60}$ Wittgenstein, 2017, p. 108 [60].

${ }^{61}$ Conant, 2001, p. 47 [7]. 
uso no jogo-de-linguagem, é, será defendido, uma expressão evoluída ou transformada de um insight que é central ao seu primeiro trabalho. ${ }^{62}$

A explicação sobre a noção de sintaxe lógica desenvolvida por essa abordagem mostra como a noção de uso pode já ser encontrada no Tractatus. Regras da sintaxe lógica são descritas como as regras manifestas e imanentes no uso de proposições significativas ${ }^{63}$. De acordo com McGuinn, o principal êxito do trabalho do primeiro Wittgenstein, expresso na distinção entre o que pode ser dito e o que pode ser mostrado, é esclarecer que a lógica diz respeito ao modo como símbolos simbolizam - algo anterior à verdade ou falsidade e que é mostrado pelo nosso uso da linguagem. A distinção dizer vs mostrar separa aquilo que é dito por meio dos símbolos das propriedades lógico-sintáticas através das quais um símbolo carrega um modo de significação específico. Aquilo que se mostra é algo expresso na nossa habilidade de usar expressões linguísticas para falar sobre o mundo. As regras da sintaxe são, sob esta perspectiva, aquilo que se mostra no uso significativo da linguagem: são o que evidencia-se por si mesmo quando sabemos como cada sinal significa ( $\mathrm{T}$ $3.334)^{64}$.

O que é mostrado no emprego da linguagem é aquilo que os sinais escamoteiam ( $\mathrm{T}$ 3.262). Uma das funções da análise lógica é precisamente trazer à superfície aquilo que é enevoado pela falta de determinação decorrente de certos usos da linguagem. McGuinn fornece uma explicação sobre a sintaxe lógica que pode ser acomodada nas distinções sobre os modos da análise tractariana. A investigação sobre a noção de sintaxe tem como objetivo esclarecer o modo regressivo presente na análise clarificatória. Um simbolismo logicamente perfeito deve obedecer a certas regras, concebidas com base na demanda pela total determinação de sentido. A eliminação de contrassensos requer a transição de um ambiente de ambiguidades para um ambiente rígido no qual tudo deve estar colocado de maneira definida. O aforismo 3.325 fornece duas regras que devem ser aplicadas à notação que visa evitar equívocos. A primeira regra estabelece que símbolos diferentes devem possuir sinais diferentes; a segunda diz que sinais que possuem símbolos diferentes não podem ser empregados superficialmente da mesma maneira.

\footnotetext{
62"The interpretation that follows is an attempt to make sense of this idea that the Philosophical Investigations is, in an important sense, a development of the ideas of the Tractatus.[...]

Thus, the move that the later Wittgenstein makes away from the idea that the meaning of a word is something that is correlated with it, and towards the idea that the meaning of a word is its use in the language-game, is, it will be argued, an evolved or transformed expression of an insight that is central to his early work." (McGuinn, 2006, p. ix-x [42].)

${ }^{63}$ Mcguinn, 2006, p. 171 [42].

${ }^{64}$ McGuinn, 2006, p. 173 [42].
} 
Uma notação que observa essas duas diretrizes obedece às regras da gramática ou sintaxe lógica. Contudo, como nota Diamond, as regras fornecidas pelo 3.325 dizem respeito ao simbolismo como um todo e não ao emprego lógico-sintático de um sinal específico. A função destas regras é proporcionar a perspicuidade necessária para que o ordenamento lógico que já configura a linguagem seja evidenciado. A ideia de total determinação é a principal diretriz que compõe o modo transformativo da análise do Tractatus, concernente à estrutura conceitual que serve de base para o trabalho analítico. Regras da sintaxe compõem o ambiente de determinação que caracteriza o discurso significativo e funcionam como princípios cuja observação caracteriza a transformação pretendida pela análise. Deste modo, as regras gerais consideradas respondem ao modo transformativo e à demanda sobre a determinação do sentido, mas não podem ser confundidas com as regras sintáticas. Sua vigência acarreta a obediência da notação às regras da

As discussões que envolvem a noção de sintaxe lógica, apesar de eslcarecerem pontos importantes, não fornecem algo que possa figurar como exemplo de regra sintática no Tractatus. Sabemos que regras sintáticas governam sinais em seu contexto de uso significativo. Se buscamos um exemplo de regra da sintaxe, é natural que seja dada atenção à noção de modo de significação, que pode ser equiparada ao uso lógico-sintático de um sinal. Nesse sentido, o aforismo 3.261 discorre sobre a diferença entre os modos pelos quais dois sinais significam:

$3.26 \mathrm{O}$ nome não pode mais ser desmembrado por meio de uma definição: é um sinal primitivo.

3.261 Todo sinal definido significa [bezeichnet] via os sinais por meio dos quais foi definido; e as definições mostram o caminho.

Dois sinais, um primitivo e outro definido por primitivos, não podem significar [bezeichnen] da mesma maneira. Nomes não podem ser dissecados por definições. ${ }^{65}$

A diferença entre um sinal primitivo e um complexo é uma diferença na maneira de significar: enquanto o primeiro não pode ser dissecado por meio de definições, o segundo é definido por meio de sinais mais simples. A simplicidade de um sinal pode ser identificada como a característica de um modo de significação específico, que corresponde a um emprego lógico sintático.

Partindo desse diagnóstico, é possível explicar como a ideia do objeto simples é dada de maneira a priori na ideia da análise clarificatória. A demanda pela determinação, característica do modo transformativo dessa análise, aparece como justificativa para a postulação de sinais simples (T 3.23).

\footnotetext{
${ }^{65}$ Wittgenstein, 2017, p. 261 (tradução modificada)[60].
} 
Outro aspecto do modo transformativo é responsável pela "reflexão" desta simplicidade nos objetos aos quais os sinais simples se referem: a ideia de que a precisão que permeia a linguagem deve caracterizar também o mundo por ela representado. Como um postulado para o caráter determinado do sentido proposicional, a simplicidade é característica do modo de significação de sinais primitivos e, neste sentido, pode ser considerada uma regra da sintaxe lógica. A ideia do objeto simples está, deste modo, contida na análise clarificatória por estar relacionada a uma regra gramatical que rege o modo de significação de sinais primitivos, postulada como uma condição para a determinação do sentido.

Dois aspectos constituintes da noção de objeto devem ser explicados sob o pano de fundo dos modos regressivo e transformativo da análise clarificatória: sua simplicidade e sua forma. Em certo sentido, ambas as características são baseadas na conexão profunda que se estabelece entre a proposição e a realidade. A simplicidade dos nomes é um requesito para que a análise completa tenha fim, pois no caso contrário a determinação do sentido proposicional seria prejudicada. Quanto à postulação dos objetos, sua existência é estabelecida no argumento da substância como um meio de evitar que o sentido de uma proposição dependa da verdade de outra, com o mesmo objetivo de manter o ambiente de determinação. A escolha da simplicidade do objeto em detrimento de sua complexidade infinita é também resultado da exigência de que a determinação da linguagem deve igualmente caracterizar o mundo. Todos esses traços mostram como a simplicidade está relacionada aos pressupostos conceituais do modo transformativo da análise. O papel do modo regressivo é evidenciado na identificação da simplicidade como uma regra da sintaxe lógica, uma marca do modo de significação de sinais primitivos.

A forma dos objetos, entendida como a característica essencial de possível aparição em fatos atômicos, é reflexo de outra demanda linguística de determinação para a significatividade de nomes. Apontamos anteriormente como a formulação da noção de forma, que estabelece que um objeto só pode ser considerado enquanto tal caso carregue consigo a possibilidade de ocorrência em fatos atômicos, é aparentada ao modo como o Princípio do Contexto é aplicado em sua formulação semântica ao estabelecer que um nome, descrito como um sinal simples que significa o objeto, só possui significado no nexo de uma proposição. Aqui faces distintas do Princípio devem ser consideradas, cada uma delas pertencentes a um modo de análise específico. A versão metodológica do Princípio, marcadamente defendida nos aforismos 3.326-7, é utilizada na tarefa de determinação da forma lógica e marca a análise clarificatória como uma investigação lógico-sintática sobre nosso uso significativo da linguagem. O 
aforismo 3.3, que expressa a versão semântica do Princípio, impõe uma condição para a significatividade de nomes, a qual pode ser considerada como uma regra para seu uso significativo.

Há uma patente dificuldade na explicação sobre as regras da sintaxe lógica do Tractatus, marcada pela falta de exemplos claros para estas regras na obra do primeiro Wittgenstein. Neste sentido, o insight de McGuinn no que diz respeito à conexão entre diferentes momentos do desenvolvimento da filosofia wittgensteineana pode fornecer uma alternativa para considerarmos tais exemplos. As regras da sintaxe lógica do Tractatus podem ser consideradas como limites do sentido, não no sentido pretendido por Hacker de um limite metafísico dado por regras que espelham possibilidades combinatorias de objetos independentes da linguagem, mas no sentido de regras sintáticas que regem um uso logicamente correto da linguagem. Portanto, cabe às regras sintáticas a função de separar aquilo que faz sentido daquilo que é contrassenso.

De acordo com Engelmann, uma tal leitura do Tractatus evita o que ele chama de aparência "paradoxicalmente autodestrutiva" do livro. Esta aparência toma lugar quando consideramos que a argumentação que leva à explicação sobre o que é um contrassenso é dada pelas sentenças do livro, as quais também são contrassensos. Se isto é o caso, então estas sentenças deveriam ser verdadeiras - o que não pode ocorrer devido à própria definição de contrassenso, que não pode ser verdadeiro nem tampouco justificar o que quer que seja. É nesse sentido que o livro parece paradoxicalmente autodestrutivo, pois se suas sentenças são verdadeiras elas devem ser contrassensos, mas se são contrassensos não podem, por definição, ser verdadeiras ${ }^{66}$. Um modo de evitar esta aparência paradoxal é entender que a distinção entre o que faz e o que não faz sentido é determinada por regras que se mostram na linguagem ${ }^{67}$.

As regras da sintaxe lógica, sendo aquilo que se mostra no uso significativo da linguagem, determinam a fronteira entre o sentido e o contrassenso. $\mathrm{O}$ discurso filosófico tractariano é, desta maneira, formado por contrassensos no sentido de que a expressão das condições para a significatividade não pode ser alvo do discurso significativo. Estas condições não são características existentes independentemente da linguagem, mas são as regras que alcançamos sob a perspectiva correta da lógica da linguagem, esta última entendida como a maneira pela qual símbolos simbolizam em nosso uso significativo das expressões. Na leitura de Engelmann, o Tractatus não fornece uma explicação sobre como a conexão entre pensamento, linguagem e realidade é estabelecida porque esta articulação já é dada na linguagem por um sistema de regras

\footnotetext{
${ }^{66}$ Engelmann, 2018, p. 592 [15].
}

${ }^{67}$ Engelmann, 2013, p. 133 [14]. 
implícito, as convenções tácitas com as quais nos comprometemos antes do início da análise ${ }^{68}$.

Assim como na leitura de McGuinn, aqui o Tractatus é visto como a origem de ideias que ganham centralidade em obras posteriores, pois a ideia de que a harmonia entre linguagem, mundo e pensamento já são dados num sistema articulado por regras é a principal característica da concepção da linguagem como cálculo defendida no The Big Typescript ${ }^{69}$. Existem, evidentemente, diferenças importantes entre as duas concepções: do ponto de vista da última obra, a gramática do Tractatus carece da autonomia que deveria caracterizar o cálculo da linguagem devido ao seu comprometimento com indefiníveis lógicos, de tal maneira que o significado não pode ser equivalente a um conjunto de regras ${ }^{70}$. Observadas as diferenças, a aproximação proposta nessa abordagem proporciona um insight importante sobre as regras da sintaxe do Tractatus. O Princípio do Contexto, expresso contrassensualmente no aforismo 3.3, é uma das proposições que não podem ser ditas e pode ser tomado como um exemplo, no Tractatus, daquilo que mais tarde será chamado de observação gramatical ${ }^{71}$. Contrassensos elucidativos tornam evidentes as regras da sintaxe e, deste modo, as proposições contrassensuais do Tractatus podem ser encaradas como observações gramaticais ${ }^{72}$. Dois aspectos concernentes ao objeto no Tractatus são tomados como regras da sintaxe pelo Wittgenstein Intermediário. O primeiro diz respeito à noção de simplicidade, considerada no The Big Typescript como uma regra gramatical ${ }^{73}$; o segundo envolve a ideia de forma dos objetos, entendida como uma contraparte ontológica do Princípio do Contexto, este último tomado como uma regra da linguagem nas Philosophische Bemerkungen ${ }^{74}$.

Dada a forte crítica resoluta à posição tradicional, é notável o reconhecimento de Conant sobre um ponto de concordância com a posição de Baker e Hacker: a concepção de gramática do segundo Wittgenstein é herdeira da concepção tractariana de sintaxe lógica ${ }^{75}$. Segundo Baker e Hacker, a concepção de sintaxe lógica defendida pelo primeiro Wittgenstein é um "grito distante" da concepção de regras da gramática defendida em seu trabalho tardio, algo que foi tomado como garantido na primeira fase de seu pensamento e tornou-

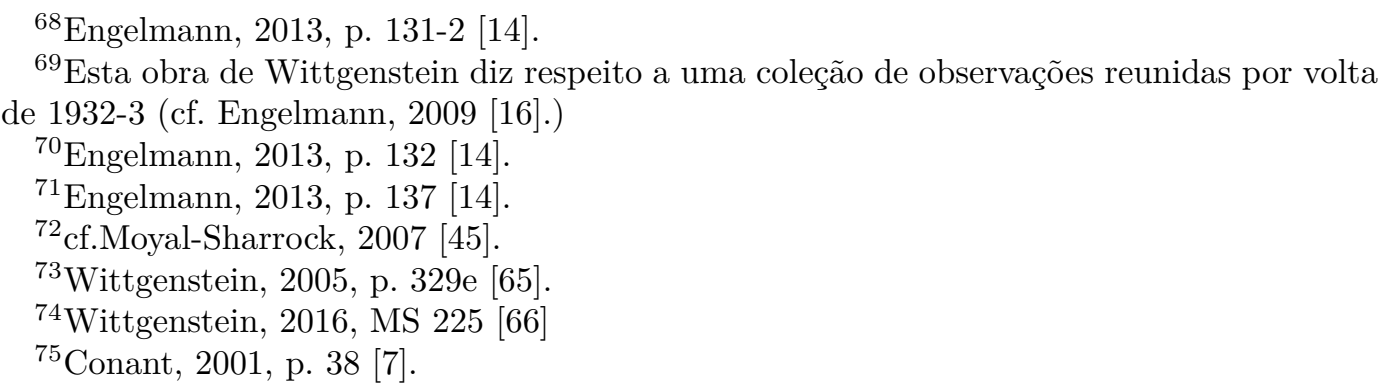


se, posteriormente, "o espetáculo de um atoleiro filosófico"76. É importante notar, contudo, que apesar da conexão entre as duas concepções, questões sobre a natureza destas regras, ou mesmo de regras em geral, não são tópico de investigações adicionais no Tractatus ${ }^{77}$.

No contexto dessa abordagem, podemos conceber o postulado dos sinais simples do Tractatus (T 3.23) como uma observação gramatical, um contrassenso que tem por objetivo explicitar a regra da simplicidade que rege o modo de significação de certos sinais. Duas características fundamentais dos nomes tractarianos são a impossibilidade de sua significação fora do contexto proposicional, expressa pelo Princípio do Contexto, e a indecomponibilidade que acompanha sua simplicidade. Estes aspectos concernentes à notação são demandas necessárias observadas no uso significativo da linguagem, concebidas como um modo de garantir o ambiente de determinações que caracteriza esse tipo de discurso. A aproximação proposta por Wittgenstein entre a linguagem e o mundo funciona de maneira tal que a determinação da primeira deve caracterizar o segundo. Tudo que faz a linguagem determinada parece ter uma contrapartida ontológica que faz com que o mundo também o seja. Isto não significa que as regras que regem o discurso existem objetivamente na realidade, mas tão somente que elas são a expressão daquilo que garante a determinação tanto daquilo que é veiculado por meio da linguagem quanto daquilo que ocorre no mundo.

Tanto a simplicidade quanto o Princípio do Contexto encontram sua expressão na noção de objeto como um resultado da ligação íntima entre linguagem e mundo. Deste modo, estas regras possuem, no Tractatus, uma conexão com o objeto simples por serem um reflexo dos aspectos que determinam sua natureza. Como o nome, o objeto é simples, porque se fosse infinitamente composto a realidade seria totalmente indeterminada; como a linguagem é determinada, a realidade que ela representa também deve ser. Logo, a simplicidade é atribuída ao objeto como um modo de garantir o caráter determinado do mundo. Esta conclusão segue a ordem de investigação exposta por Wittgenstein no aforismo 5.4711: primeiro a análise fornece a essência da proposição (neste caso, expressa nas regras evidenciadas pelo uso lógico da linguagem) e, como consequência, a essência do mundo também é alcançada.

O conflito que ocorre na formulação da noção de objeto pode ser interpretado como um reflexo do conflito estabelecido entre as duas regras sintáticas consideradas. O Princípio do Contexto atrela a significatividade do nome ao nexo proposicional; é, desta maneira, uma demanda holista, pois a

\footnotetext{
${ }^{76}$ Baker e Hacker, 2009, p. 43 [2].

${ }^{77}$ David Stern, 1995, p. 50 [58].
} 
determinação do significado de uma das partes da proposição depende desta última como um todo. Por outro lado, o nome, enquanto sinal primitivo, carregará a demanda atomista de possuir seu significado de maneira totalmente independente de quaisquer combinações específicas de nomes em proposições. Da mesma maneira, encontramos no objeto a simplicidade absoluta que se traduz em sua subsistência totalmente independente da existência ou nãoexistência de fatos atômicos. Esta independência é, no entanto, definida como a capacidade de ocorrência em todas as situações possíveis, entendida como uma forma de conexão com o fato atômico que torna o objeto dependente dos fatos nos quais pode ocorrer. A forma dos objetos apresenta, deste modo, um vínculo essencial entre a subsistência do objeto e a ocorrência de fatos atômicos, tornando a substância algo ao mesmo tempo dependente e independente daquilo que ocorre. 


\section{5}

\section{Conclusão}

A investigação empreendida tratou de diferentes aspectos conceituais relacionados à formulação da noção de objeto simples no Tractatus, os quais são de suma importância na trama tractarianas. A argumentação que conclui a necessidade da existência de uma substância lida com as condições para a determinação do sentido proposicional, o que nos leva diretamente à distinção entre o que pode ser dito pelo discurso significativo e o que pode tão somente ser mostrado. A existência dos objetos é algo que se mostra; sua justificação, ao lidar com as condições para o discurso significativo, ocorre através de uma argumentação transcendental. O sentido no qual este "mostrar" deve ser encarado só ficará claro, contudo, após o esclarecimento do modo pelo qual a análise lógica "contém" a ideia do simples, e chega à sua existência de maneira totalmente a priori.

Podemos dizer que o objeto está contido na ideia de análise a partir de ao menos duas perspectivas. A primeira delas parte da ideia de uma análise completa da proposição, cujo resultado seria o alcance de proposições elementares constituídas pela combinação de sinais simples cujo significado são objetos simples. Wittgenstein reconhece, contudo, não ser capaz de empreender uma tal análise completa, apesar de presumir, também em bases puramente lógicas, que esta análise é possível. A segunda perspectiva é a de uma análise clarificatória que pretende substituir a linguagem ordinária por uma notação que evidencie sua estrutura lógica escondida. Sob esta perspectiva, argumentamos que o objeto pode ser entendido como uma espécie de resultado da postulação de diferentes regras gramaticais sobre o uso significativo da linguagem.

Sob a luz de uma análise clarificatória, abordamos os dois principais aspectos relativos à essência do objeto tractariano: simplicidade e forma. Vimos como reflexões nos Notebooks revelam que uma análise infinita é seriamente considerada como um modelo de análise lógica e que a escolha da simplicidade em detrimento da divisibilidade infinita é calcada num pressuposto conceitual básico da teoria da figuração do primeiro Wittgenstein. Este pressuposto coloca linguagem e mundo em pé de igualdade no que concerne ao seu caráter determinado, ensejando um sentido no qual podemos entender o "espelhamento" de aspectos da realidade em nosso discurso: aquilo que, na linguagem, faz com que ela seja determinada, é reflexo do modo através do qual o mundo também possui sua determinação. É nesse sentido que as regras 
da sintaxe podem ser entendidas como um reflexo da realidade: linguagem e mundo funcionam de maneiras bastante próximas.

A nossa atenção para com a noção de forma é, por sua vez, resultado de uma abordagem sobre a proximidade entre objetos e itens de natureza fenomênica exibida na analogia encontrada nos aforismos 2.013-2.0131. A analogia apresenta uma comparação entre um objeto e itens como "objeto espacial" e "mancha no campo visual", identificando para ambos a existência de um espaço circundante sem o qual não podem ser concebidos. Esta comparação visa elucidar a ideia de acordo com a qual todas as possibilidades de ocorrência em fatos atômicos devem estar, de alguma maneira, prejugadas na natureza do objeto ( $\mathrm{T}$ 2.0123). Nesse contexto, dizemos que os objetos contêm a possibilidade de todas as situações ( $\mathrm{T}$ 2.014) porque possuem a possibilidade de ocorrência em fatos atômicos gravada em sua essência através de sua forma (T 2.0141). Não se trata de atribuir a conjugação do objeto com um espaço de fatos atômicos possíveis, como se estes últimos estivessem já dados em sua essência, mas sim sobre a capacidade, inerente à natureza do objeto, de ocorrer em fatos atômicos.

A investigação sobre a noção de forma revela também a importância do Princípio do Contexto de Frege na filosofia tractariana. O uso wittgensteineano desse princípio perpassa, assim como nos Grundlagen, uma formulação semântica e outra metodológica. A formulação metodológica ocorre nos aforismos 3.326-7 e condiciona a determinação da forma lógica ao reconhecimento dos diferentes modos de significação (ou símbolos) dos sinais no contexto do uso significativo da linguagem. A formulação semântica é aplicada tanto a nomes constantes (T 3.3) como a nomes variáveis ou expressões (T 3.314). No último caso, as variáveis possuem a mesma função atribuída por Frege ao uso de letras em expressões matemáticas: munir o conteúdo proposicional de generalidade. Esta generalidade caracteriza a forma lógica de afiguração (ou forma da realidade), através da qual uma figuração é capaz de figurar a realidade como um todo ( T 2.18) - diferentemente do que ocorre na figuração de um aspecto particular da realidade, que pressupõe somente uma forma de afiguração, a qual não possui a mesma generalidade ( $\mathrm{T} 2.17$ ).

A forma dos objetos, entendida como sua possibilidade de ocorrência em fatos atômicos, resulta de um movimento conceitual anteriormente criticado por Frege, o qual consiste em tratar a referência dos sinais linguísticos nos termos da relação entre partes e todo existente no nível proposicional. De acordo com Frege, no âmbito do significado não é admitida a determinação de uma parte pelo todo ou vice-versa. Wittgenstein vai de encontro a esta prerrogativa na sua formulação da noção de objeto, ao afirmar que sua 
capacidade de ocorrer em todas as situações é uma forma de dependência para com o fato atômico ( $\mathrm{T}$ 2.0122). A forma dos objetos tractarianos é, desta maneira, uma espécie de formulação ontológica do Princípio do Contexto: assim como um objeto não pode ser pensado fora de sua liga no fato atômico ( $\mathrm{T}$ 2.0121), também o nome não pode ser significativo fora da sua conexão com outros nomes no nexo proposicional.

Após a discussão sobre as formas tractarianas, foi possível prosseguir com a investigação sobre a análise lógica. Desde que procuramos o modo como a ideia do objeto simples está contida na ideia de análise, é preciso explicar também como a forma dos objetos, em sua aproximação com o Princípio do Contexto, é atestada no interior desta análise. Vimos que a tomada da análise completa da proposição como método filosófico do Tractatus acarreta circularidade, pois a determinação da forma lógica a ser encontrada no fim desta análise já pressupõe o correto entendimento da lógica da linguagem. A alternativa apresentada foi a de uma análise clarificatória, cujos pressupostos foram esclarecidos pela investigação sobre os modos de análise tractariana.

A ideia de decomposição de compostos em partes mais simples é marca do modo decomposicional de análise que, na abordagem tractariana, encontrase como que subordinado aos modos transformativo e regressivo. Como marca do modo transformativo de análise identificamos a substituição do emprego cotidiano da linguagem por um uso logicamente correto como uma exigência para que a estrutura lógica de nosso discurso venha à tona. Esta estrutura é, por seu turno, constituída das regras gramaticais que se mostram no uso significativo da linguagem, cuja formulação está relacionada ao modo regressivo de análise. Regras da gramática ou sintaxe lógica são princípios gerais que devem ser observados na garantia do caráter determinado do sentido e são reflexo de certos aspectos do mundo na medida em que outro pressuposto do modo transformativo é observado, qual seja, a ideia de que linguagem e mundo são igualmente determinados.

Prosseguimos com uma investigação sobre a maneira pela qual as regras da sintaxe lógica estão relacionadas ao estabelecimento de limites para o que pode ser dito, distinguindo sentido e contrassenso. Endossamos a crítica resoluta $^{1}$ à ideia de que contrassensos são originados por usos da linguagem que violam as possibilidades combinatoriais de nomes, regidas por regras sintáticas que espelham as possibilidades combinatoriais de objetos em fatos atômicos, defendida na postura tradicional de Hacker² . A função iluminadora dos contrassensos tractarianos deve ser entendida sob a luz da tarefa elucidativa

${ }^{1}$ Conant, 2001 [7]; Diamond, 2005 [11].

${ }^{2} 1986$ [31]. 
da filosofia. A diferença entre sentido e contrassenso é baseada nas leis da sintaxe lógica e contrassensos elcucidativos possuem a função de precipitar aquilo que se mostra no uso signiticativo de expressões linguísticas: as regras para seu uso lógico e determinado.

A importância das considerações sobre uso no Tractatus é algo apontado pela abordagem resoluta, a qual, no entanto, não avança uma explicação mais completa sobre as regras sintáticas. A posição de Marie McGuinn ${ }^{3}$ parece desenvolver justamente este aspecto ao apontar como aquilo que se mostra, revelando algo inefável, é expresso em nossa habilidade linguística de veicular um discurso com sentido determinado. Os contrassensos elucidativos tractarianos podem ser entendidos como observações gramaticais, cujo objetivo é explicitar as regras imanentes ao nosso uso da linguagem que permitem a diferenciação entre os discurso contrassensual e significativo. Este modo de ler a primeira filosofia de Wittgenstein identifica uma conexão entre a noção de gramática que ganha centralidade nas reflexões de seu período intermediário e a ideia de sintaxe lógica apresentada no Tractatus.

Outra observação importante, fornecida por Engelmann, é a de que o Princípio do Contexto pode ser tomado como um exemplo tractariano de observação gramatical. Por seu turno, a simplicidade é um aspecto que diz respeito ao modo de significação dos sinais, este último entendido como seu emprego lógico-sintático. Os dois aspectos, que dizem respeito à linguagem, podem ser tomados como regras que devem ser observadas para seu uso lógico, alcançadas no contexto da análise clarificatória tractariana. Como uma consequência do aspecto transformativo desta análise, estas regras são encaradas como um reflexo daquilo que dá ao mundo seu caráter determinado. A simplicidade dos nomes, enquanto postulado para o caráter determinado do sentido, é também atribuída aos objetos como uma garantia desta mesma determinação. Do mesmo modo, o Princípio do Contexto é uma demanda sobre a significatividade de nomes próprios que reflete a dependência ontológica do objeto para com o fato atômico, expressa na noção de forma dos objetos. $\mathrm{O}$ conflito que ocorre na formulação do objeto tractariano, que deve ser simples e independente do que é o caso e, ao mesmo tempo, dependente de sua possibilidade de ocorrência em fatos atômicos (i.e., sua forma), é refletido pelo conflito que, na linguagem, ocorre entre o princípio de acordo com o qual o significado de nomes é dependente de sua ocorrência no nexo proposicional e a demanda de que sinais simples possuam seu significado de maneira totalmente independente. 


\section{Referências bibliográficas}

[1] BAKER, G. P; HACKER, P. M. S.. Wittgenstein: Understanding and Meaning Part I: Essays. Blackwell Publishing, 2005. Second, extensively revised edition by P. M. S. Hacker. 18, 40

[2] BAKER, G. P; HACKER, P. M. S.. Wittgenstein: Rules, Grammar and Necessity. Blackwell Publishing, 2009. Second, extensively revised edition by P. M. S. Hacker. 76

[3] BARBOSA FILHO, B.. Aristóteles e o princípio da bivalência. Analytica, 9(1):173-184, 2009. 12

[4] BEANEY, M.. Decompositions and transformations: Conceptions of analysis in the early analytic and phenomenological traditions. The Southern Journal of Philosophy, 40:53-99, 2002. 10, 11, 12, 22

[5] BLANCHETTE, P. A.. Frege's Conception of Logic. Oxford University Press, Oxford, 2012. 16, 17

[6] CHEUNG, L. K. C.. Variable names and constant names in Wittgenstein's Tractatus. Philosophical Investigations, 28(1):14-42, 2005. 35

[7] CONANT, J.. Two conceptions of die Überwindung der Metaphysik: Carnap and early Wittgenstein. In: McCarthy, T; Stidd, S. C., editor, WITTGENSTEIN IN AMERICA, p. 13-61. Clarendon Press, Oxford, 2001. 20, 38, 39, 41, 42, 46, 56, 57, 59, 61, 75, 1

[8] COPI, I. M.. Objects, properties and relations in the 'tractatus'. In: Copi, I. M.; Beard, R. W., editor, ESSAYS ON WITTGENSTEIN'S Tractatus, p. 167-186. The Macmillan Company, New York, 1966. 54

[9] CUTER, J. V. G.. A lógica do Tractatus. Manuscrito, 25(1):87-120, 2002. 31, 36

[10] DIAMOND, C.. The Realistic Spirit: Wittgenstein, philosophy and the mind. MIT Press, Cambridge and Massachussets, 1995. 27, 28, $29,47,49,52,54$

[11] DIAMOND, C.. Logical syntax in Wittgenstein's Tractatus. The Philosophical Quaterly, 55(218):78-89, 2005. 44, 45, 1 
[12] DREBEn, B.; FLOYD, J.. Tautology: How not to use a word. In: Hintikka, J., editor, WITTGENSTEIN IN FLORIDA, p. 149-219. Springer Sciende+Business Media, 1991. 32

[13] DUMMETT, M.. Frege: Philosophy of Language. Harper \& Row, New York, Evanston, San Francisco, London, 1973. 39

[14] ENGELMANN, M.. Wittgenstein's Philosophical Development. Palgrave MacMillan, 2013. 47, 30, 67, 68, 70, 71

[15] ENGELMANN, M.. What does it take to climb the ladder? (a sideways approach). Kriterion, (140):591-611, 2018. 51, 66

[16] EnGELmann, M.. O que é o Big Typescript? Doispontos, 6(1):3561, Oct. 2009. 69

[17] FOGELIN, R.. Wittgenstein. Routledge, London and New York, 2 edition, 1995. 27

[18] FRASCOLLA, P.. On the nature of tractatus objects. Dialectica, 58(3):369-382, 2004. 40, 55

[19] FRASCOLLA, P.. Understanding Wittgenstein's Tractatus. Routledge, London and New York, 2006. 41, 43

[20] FREGE, G.. Die Grundlagen der Arithmetik. Verlag von Wilhelm Koebner, Breslau, 1884. 7

[21] FREGE, G.. Os Fundamentos da Aritmética. In: Civita, V., editor, OS PENSADORES XXXVI, p. 201-282. Abril Cultural, 1974. Seleção e Tradução de Luís Henrique dos Santos. 8, 10, 12, 13, 14, 15, 22, 38

[22] FREGE, G.. Funktion und Begriff (1891). In: Pätzig, G., editor, FUNKTION, BEGRIFF, BEDEUTUNG: FÜNF LOGISCHE STUDIEN, p. 1-22. Vandenhoeck \& Ruprecht, 2008. 16

[23] FREGE, G.. Über Sinn und Bedeutung (1892a). In: Pätzig, G., editor, FUNKTION, BEGRIFF, BEDEUTUNG: FÜNF LOGISCHE STUDIEN, p. 23-46. Vandenhoeck \& Ruprecht, 2008. 16

[24] FREGE, G.. Ünd Begriff und Gegenstand (1892b). In: Pätzig, G., editor, FUNKTION, BEGRIFF, BEDEUTUNG: FÜNF LOGISCHE STUDIEN, p. 47-60. Vandenhoeck \& Ruprecht, 2008. 16

[25] FREGE, G.. The Foundations of Arithmetic. Harper \& Brothers, New York, 2 edition, 1960. Translated by J. L. Austin. 24 
[26] FREGE, G.. Über die grundlagen der geometrie i. Jahresbericht der Deutschen Mathematiker, 15:293-309, 1906. 32, 33

[27] FREGE, G.. Begriffsschrift, eine der arithmetischen nachgebildete Formelsprache des reinen Denkens. Louis Nebert, 1879. 41

[28] FREGE, G.. Sobre o sentido e a referência. In: Alcoforado, P., editor, LÓGICA E FILOSOFIA DA LINGUAGEM, p. 129-158. EDUSP, 2 edition, 2009. Seleção, introdução, tradução e notas de Paulo Alcoforado. 42

[29] FRIEDLANDER, E.. Signs of Sense: Reading Wittgenstein's Tractatus. Harvard University Press, Cambridge and London, 2001. 2

[30] GOODMAN, N.. The Structure of Appearance. D. Reidel Publishing Company, Dordrecht and Boston, 3 edition, 1977. with an introduction by Geoffrey Hellman. 42

[31] HACKER, P.. Insight and Illusion: themes in the philosophy of Wittgenstein. Clarendon Press, 1986. 35, 36, 37, 48, 50, 55, 2

[32] HACKER, P. M. S.. Wittgenstein, Carnap, and the new american wittgensteinians. The Philosophical Quaterly, 53(210):1-23, 2003. 43

[33] HYDER, D.. The Mechanics of Meaning. Walter De Gruyter, Berlin and New York, 2002. 14, 15, 43

[34] ISHIGURO, H.. Use and reference of names. In: Winch, P., editor, STUDIES IN THE PHILOSOPHY OF WITTGENSTEIN, p. 20-51. Routledge \& Kegan Paul, 1969. 26, 27, 28

[35] JACQUETTE, D.. Tractatus objects and the logic of color incompatibility. In: Silva, M., editor, COLOURS IN THE DEVELOPMENT OF WITTGENSTEIN'S PHILOSOPHY, p. 57-94. Palgrave Macmillan, 2017. 36, 37

[36] JOHNSTON, C.. Symbols in wittgenstein's Tractatus. European Journal of Philosophy, 15(3):367-394, 2007. 29, 30

[37] LAMPERT, T.. Wittgensteins Physikalismus: Die Sinnesdatenanalyse des Tractatus Logico-Philosophicus in Ihrem Historischen Kontext. Mentis, Paderbon, 2013. 2

[38] MALCOLM, N.. Nothing is Hidden: Wittgenstein's Criticism of his Early Thought. Basil Blackwell, 1986. 52 
[39] MALCOLM, N; WRIGHT, G. H.. Ludwig Wittgenstein: A Memoir. Clarendon Press, Oxford, 2 edition, 2001. 7

[40] MARQUES, E. D. R.. Sobre a distinção entre tatsache e sachverhalt no Tractatus Logico-Philosophicus de ludwig wittgenstein. O que nos faz pensar, 2(2):54-61, 1990. 5

[41] MARQUES, J. O. A.. A ontologia do Tractatus e o problema dos Sachverhalte não-subsistentes. O que nos faz pensar, 3(5):51-66, 1991. 5

[42] MCGUINN, M.. Elucidating the Tractatus: Wittgenstein's Early Philosophy of Logic and Language. Clarendon Press, Oxford, 2006. $62,63,64,3$

[43] MORRIS, M.. Routledge Philosophy Guidebook to Wittgenstein and the Tractatus Logico-Philosophicus. Routledge, 2008. 2

[44] MORRIS, M.. The substance argument of wittgenstein's Tractatus. Journal for the History of Analytical Philosophy, 4(7):1-13, 2013. 2

[45] MOYAL-SHARROCK, D.. The good sense of nonsense: a reading of Wittgenstein's Tractatus as nonself-repudiating. Philosophy, 1(82):147-77, Jan. 2007. 72

[46] PHILliPS, D. M.. Complete analysis and clarificatory analysis in Wittgenstein's Tractatus. In: Beaney, M., editor, THE ANALYTIC TURN: ANALYSIS IN EARLY ANALYTIC PHILOSOPHY AND PHENOMENOLOGY, p. 164-177. Routledge, 2007. 18, 19, 20, 21, 25

[47] PROOPS, I.. Wittgenstein on the substance of the world. European Journal of Philosophy, 12(1):106-126, 2004. 2, 4, 9, 28, 29

[48] RAMSEY, F. P.. Review of 'Tractatus'. In: Copi, I. M.; Beard, R. W., editor, ESSAYS ON WITTGENSTEIN'S Tractatus, p. 9-24. The Macmillan Company, New York, 1966. 44, 46

[49] RECK, E. H.. Frege-russell numbers. In: Beaney, M., editor, THE ANALYTIC TURN: ANALYSIS IN EARLY ANALYTIC PHILOSOPHY AND PHENOMENOLOGY, p. 33-50. Routledge, 2007. 21, 37, 14

[50] RICKETTS, T.. Concepts, objects and the context principle. In: Potter, M; Ricketts, T., editor, THE CAMBRIDGE COMPANION TO FREGE, p. 149-219. Cambridge university Press, New York, 2010. 9 
[51] RUFFINO, M.. O princípio do contexto em frege e wittgenstein. Master's thesis, Universidade Estadual de Campinas, Instituto de Filosofia e Ciências Humanas, Campinas, SP, 1990. Disponível em: <http://www.repositorio.unicamp.br/handle/REPOSIP/279320>. 11, 19,23

[52] SANTOS, L. H. L.. A harmonia essencial. In: Novaes, A., editor, A CRISE DA RAZÃO. Companhia das Letras, 1996. 11, 13

[53] SILVA, M.. Holismo e verofuncionalidade: sobre um conflito lógico filosófico essencial. Philósophos, 18(2):167-200, 2013. 49

[54] SOUTIF, L.. Minima visibilia, single-colored patches, points: Logical analysis and its visual instances in wittgenstein's early notebooks. In: Silva, M., editor, COLOURS IN THE DEVELOPMENT OF WITTGENSTEIN'S PHILOSOPHY, p. 9-32. Palgrave Macmillan, 2017. 35, 1, 3, 4, 5, 9

[55] SOUTIF, L.. Simplicity or singularity? two conceptions of object in the TLP. Argumentos, 5(10):97-110, 2013. 39, 51

[56] SOUZA, E. C.. Platão, Wittgenstein e a necessidade. Trans/Form/Ação, 34(3):17-30, 2011. 31

[57] STENIUS, E.. Wittgenstein's Tractatus. Cornell University Press, New York, 1964. 5

[58] STERN, D. G.. Wittgenstein on Mind and Language. Oxford University Press, New York, Oxford, 1995. 77

[59] STERN, R.. Transcendental Arguments and Scepticism: Answering the Question of Justification. Oxford University Press, 2000. 5

[60] WitTGenstein, L.. Tractatus Logico-Philosophicus. Editora da Universidade de São Paulo, 3 edition, 2017. Tradução, apresentação e ensaio introdutório de Luiz Henrique Lopes dos Santos; introdução de Bertrand Russell. 1, 2, 3, 6, 21, 22, 24, 26, 38, 45, 48, 3, 4, 25, 34, 45, 46, $47,17,23,24,26,34,53,58,60,65$

[61] WiTTGEnSTEIN, L.. Tractatus Logico-philosophicus/Logischphilosophische Abhandlung. Webpage, 2018. Syde-by-syde edition version 0.53, containing the original German, alongside both the Ogden/Ramsey, and Pears/McGuinness English translations. Disponível em: http://people.umass.edu/klement/tlp/ . Acesso em 05 abr. 2021. 2 
[62] WITTGEnStein, L.. Notebooks 1914-1916. Harper \& Row, New York and Evanston, 1969. Edited by G. H. von Wright and G. E. M Anscombe, with an English translation by G. E. M Anscombe. 10, 16, 17, $18,19,20,23,25,32,34,1,44,6,7,8,15,16$

[63] WITTGEnSteIN, L.. Philosophical Investigations. Wiley-Blackwell, 4 edition, 2009. The German text, with an English translation by G. E. M. Anscombe, P. M. S. Hacker and Joachim Schulte. Revised 4th edition by P. M. S. Hacker and Joachim Schulte. 30

[64] Wittgenstein, L.. Philosophical Remarks. Basil Blackwell, Oxford, 1975. 50

[65] WitTGenstein, L.. The Big Typescript, TS 213. Blackwell Publishing, 2005. 73

[66] WITtGenstein, L.. Wittgenstein Nachlass Ms 110: Philosophische Bemerkungen (WL). Wittgenstein Archives at the University of Bergen, Bergen, 2016. Edited by the Wittgenstein Archives at the University of Bergen (WAB) under the direction of Alois Pichler. Disponível em: http://wab.uib.no/transform/wab.php?modus=opsjoner . Acesso em 05 abr. 2021. 74

[67] WITtGenstein, L; LEE, D.. Wittgenstein's Lectures: Cambridge, 1930-1932. Basil Blackwell, Oxford, 1980. from the notes of John King and Desmond Lee. 33

[68] WITTGENSTEIN, L; MCGUINNESS, B.. Wittgenstein in Cambridge: Letters and Documents 1911-1951. Blackwell Publishing, 2008. 5, 31, 33 